\title{
Labour market and unemployment in Sudan
}

Citation for published version (APA):

Nour, S. (2011). Labour market and unemployment in Sudan. UNU-MERIT, Maastricht Economic and Social Research and Training Centre on Innovation and Technology. UNU-MERIT Working Papers No. 007 https://doi.org/10.2139/SSRN.1949171

Document status and date:

Published: 01/01/2011

DOI:

10.2139/SSRN.1949171

Document Version:

Publisher's PDF, also known as Version of record

\section{Please check the document version of this publication:}

- A submitted manuscript is the version of the article upon submission and before peer-review. There can be important differences between the submitted version and the official published version of record.

People interested in the research are advised to contact the author for the final version of the publication, or visit the DOI to the publisher's website.

- The final author version and the galley proof are versions of the publication after peer review.

- The final published version features the final layout of the paper including the volume, issue and page numbers.

Link to publication

\footnotetext{
General rights rights.

- You may freely distribute the URL identifying the publication in the public portal. please follow below link for the End User Agreement:

www.umlib.nl/taverne-license

Take down policy

If you believe that this document breaches copyright please contact us at:

repository@maastrichtuniversity.nl

providing details and we will investigate your claim.
}

Copyright and moral rights for the publications made accessible in the public portal are retained by the authors and/or other copyright owners and it is a condition of accessing publications that users recognise and abide by the legal requirements associated with these

- Users may download and print one copy of any publication from the public portal for the purpose of private study or research.

- You may not further distribute the material or use it for any profit-making activity or commercial gain

If the publication is distributed under the terms of Article $25 \mathrm{fa}$ of the Dutch Copyright Act, indicated by the "Taverne" license above, 


\section{UNITED NATIONS \\ UNIVERSITY}

UNU-MERIT

\section{Working Paper Series}

\section{\#2011-007}

\section{Labour Market and Unemployment in Sudan By Samia Satti Osman Mohamed Nour}




\section{UNU-MERIT Working Papers}

ISSN 1871-9872

Maastricht Economic and social Research and training centre on Innovation and Technology, UNU-MERIT

UNU-MERIT Working Papers intend to disseminate preliminary results of research carried out at the Centre to stimulate discussion on the issues raised. 


\title{
Labour Market and Unemployment in Sudan
}

\author{
By Dr. Samia Satti Osman Mohamed Nour ${ }^{1}$
}

(January 2011)

\begin{abstract}
This paper examines the structure of labour market and unemployment in Sudan. One advantage of our analysis in this paper is that we explain several stylized facts on labour market using new secondary data on population, employment and unemployment based on Sudan Central Bureau of Statistics (2010) the Fifth Sudan Population and Housing Census (2008). An interesting element in our analysis is that we explain several stylized facts on the relation between structure of labour market and demographic structure, labour force, participation rates, economic activities, low skill level and high unemployment rate defined by gender, mode of living and main geographic areas in Sudan. Different from the findings in the empirical literature in support of Phillips curve on the negative correlation between inflation and unemployment rates, we find positive and significant correlation between unemployment and inflation rates in Sudan during the period (2000-2008). Moreover, different from the analysis in the Sudanese literature we present a more comprehensive analysis of four stylized facts on unemployment problem in Sudan, these include distinction of several types of unemployment; interpretation of unemployment problem from two different endogenous and exogenous perspectives due to endogenous and exogenous causes; analysis of high incidence of unemployment among youth population and high mismatch between educational qualifications -supply- and labour market requirements- demand. The major policy implication from our findings indicate that since unemployment problem is related to these endogenous and exogenous causes, therefore, policies intervention for reducing unemployment should deal with these endogenous and exogenous causes. Notably, improvement of job creation and quality of educational policies and consistency between educational qualifications (output) and labour market requirements. Another major policy implication from our result on the significant positive correlation between increase in unemployment and inflation rates (2000-2008), implies that macroeconomic policies aimed at or targeting reducing inflation rates would also contribute to reduce unemployment rates in Sudan.
\end{abstract}

Keywords: Labour market, employment, unemployment, Sudan.

JEL classification: E24, J10, J11, J20, J21, J23, J24, J64

\footnotetext{
${ }^{1}$ Corresponding Author: Dr. Samia Satti Osman Mohamed Nour, Visiting Research Fellow - University of Maastricht, School of Business and Economics, UNU-MERIT, Maastricht, the Netherlands; and Assistant Professor of Economics, Economics Department, Faculty of Economic and Social Studies, Khartoum University, Khartoum, Sudan. E-mail: samiasatti@yahoo.com; samia_satti@hotmail.com. The first draft of this paper was originally prepared within the author's research project "Technological Change and Skill Development: the case of Sudan" during the author's time as a visiting research fellow at the University of Maastricht, School of Business and Economics, UNU-MERIT, Maastricht, the Netherlands. The author gratefully acknowledges the Arab Fund for Economic and Social Development, Kuwait, for research grant and fellowship and University of Maastricht, School of Business and Economics, UNU-MERIT for the good hospitality during her visiting research fellowship. The author would like to gratefully thank Prof. Joan Muysken and Dr. Hisham Mohamed Hassan for their useful comments on the first draft of this paper. All the usual disclaimers apply.
} 


\section{Introduction}

Economists have long recognized the essential role of full employment and equity for achieving sustainability and improvement of economic growth in any society. Both the classical and new growth theories and empirical literature indicate that full employment and equilibrium in the labour market is an objective that every economy aims to fulfill. Failure to achieve full employment and the incidence of unemployment problem and their serious implications on causing mismatch between supply of and demand for labour could have several macroeconomic effects and hindering the process of economic growth and development. Therefore, every country aims to achieve full employment to avoid the negative consequences of unemployment.

Different schools of thoughts use different definitions, conceptual frameworks and interpretations of unemployment problem. Theoretical and empirical literature presents a comprehensive discussion of the causes and consequences of unemployment problem from both supply and demand perspectives. The Classical school focuses on the supply side and interprets the unemployment problem due to excess supply of labour. For the New Classical school the unemployment problem can be attributed to the rigidity in wages. The Keynesian school focuses on the demand side and attributes the unemployment problem due to deficient demand, involuntary (compulsory) unemployment. According to the International Labour Organization (ILO) unemployment refers to all people who are not currently working, not employed and are currently looking for jobs (at the available wage rate) in the market, but unable to find a suitable job, at the prevalent wage rate. The rate of unemployment refers to the share of the labour force that is without work but available for and seeking employment. The definition of ILO explained unemployment mainly due to the surplus supply of labour.

More recently, the long run economic growth and sustainable development strategy in the Sudan aims to achieve and sustain peace and to shift to political and economic stabilization, balanced development strategies, economic diversification, build of adequate human resources, build institutional reform and enhance self-reliance on domestic capital and workers. In addition, overcoming the strategic problems and challenges confronting economic development and thereby achieving economic growth and sustainable development in the Sudan depends on the strategies of alleviation of poverty and reducing unemployment and restructuring the labour market. In our opinion the success/fulfilment of the strategies of reducing unemployment and poverty problems are interrelated. In particular, confronting with the challenge of poverty alleviation depends on the creation or development of adequate and appropriate employment opportunities in the Sudan, notably, the creation of more permanent jobs implies more sufficient and sustainable income available for the poor and that will help to reduce the poverty rate.

Explaining the case of Sudan is both interesting and significant because of high and recent increasing unemployment rate in Sudan. Moreover, both the growing inflow of FDI and 
the increased wealth from oil has encouraged migration to the Sudan. Consequently, migrant workers have increased in the labour market, particularly in the private sector that also probably affected the structure of labour market and contributed to the growing unemployment rate. In addition, the Sudan suffered from structural problems related to the lack of political stability, continuous conflict, regional disparities due to imbalanced development strategies, poverty and low skill level which has also affected the structure of labour market and contributed to high unemployment rate. Hence, the upskilling and creation of employment become imperative to overcome the strategic problems and challenges confronting economic development in Sudan.

Based on the above, this paper examines the structure of labour market and unemployment in Sudan, the aim of this paper is twofold: first, to present some stylized facts on the structure of labour market in Sudan and second to present some stylized facts to examine more extensively the unemployment problem confronting economic development in Sudan. An interesting element in our analysis is that we explain several stylized facts on the labour market, First we explain the relation between the structure of labour market and the demographic structure, participation rates and economic activities, second we show the relation between the structure of labour market and the low skill level and brain drain problems and finally we examine the relation between the structure of labour market and the unemployment and youth unemployment problem in Sudan. We show that the differences in the structure and distribution of the total population defined by age, gender, mode of living and main geographic areas have several important implications in the structure of labour market, labour force, participation rates, economic activities, skill level, employment rates and unemployment rates. Moreover, different from the analysis in the Sudanese literature we present a more comprehensive analysis of four stylized facts on unemployment problem in Sudan, these include distinction of several types of unemployment; interpretation of unemployment problem from two different endogenous and exogenous perspectives due to endogenous and exogenous causes; analysis of high incidence of unemployment among youth population and high mismatch between educational qualifications supply- and labour market requirements- demand. Moreover, one advantage of our analysis in this paper is that we explain these stylized facts on labour market and unemployment using new secondary data on population, employment and unemployment based on Sudan Central Bureau of Statistics (2010) the Fifth Sudan Population and Housing Census (2008). One limitation of our analysis in this paper is that the use of figures on registration and employment to refer to supply of and demand for youth and university graduates labour respectively may be somewhat inaccurate and underestimate the actual figures on supply of and demand for university graduates, because not all youth and university graduates looking for jobs are registered for the federal public service recruitment board and also because figures on employment may include youth and university graduates unregistered for the federal public service recruitment board. Apart from this limitation, our analysis in this paper is interesting and useful to improve 
understanding since we provide a more comprehensive investigation and discuss the unemployment problem from both endogenous and exogenous perspectives. In addition, our analysis is useful from policy perspective to address the relevant mechanisms and policy issues to reduce unemployment, highlight the role of both public and private labour market institutions and educational policies and the need for incentives, agreement and collaboration between public and private institutions in upgrading skill and reducing unemployment problem in Sudan.

The rest of this paper is organized in the following way. Section 2 explains the general socioeconomic characteristics of Sudan, Section 3 discusses the structure of labour market and unemployment in Sudan and Section 4 concludes.

\section{Economic characteristics and strategic problems for development in the Sudan}

Before assessing the structure of labour market and unemployment problem in the Sudan it is useful to start by explaining the general political context and socio-economic characteristics of the Sudan. Next, we show the structural problems related to the structure of labour market, unemployment and low skill level in the next section and we attempt to link these to general socio-economic characteristics of Sudan.

\section{1. Geo-political setting, political context and north-south conflict in the Sudan}

Starting with the geographical location and features, geographically, Sudan is situated in northern (or northeastern) Africa, it is the largest country on the Africa continent and the Arab region and the tenth largest in the world in terms of area covering 2492360 square kilometers or about (967500 square miles) i.e. nearly one - tenth of the total area of Africa. Sudan has lengthy borders with nine countries and for its strategic location; Sudan seems as a bridge between Arab and Africa regions. ${ }^{2}$ The principal physical feature of the Sudan is the river Nile and its tributaries. The world's longest river, the Nile, divides Sudan between east and west sides. The Nile system run through approximately 2.5 thousand miles from south to north, the Blue Nile River joins the White Nile River at Khartoum to form the river Nile. The Nile flood provides Sudan with vast alluvial agricultural lands and the most fertile region between the White Nile River and Blue Nile River. The climate of Sudan ranges from the equatorial in the extreme south to an arid desert in the north. ${ }^{3}$

As for the political context since independence in 1956 and over the past five decades Sudan was ruled by three civilian governments (1956-1958, 1964-1969 and 1985-1989) and three Military governments (1958-1964, 1969-1985, 1989-2005). Sudan suffered from political instability, as the short-lived three civilian governments were often removed and overthrown by

\footnotetext{
${ }^{2}$ Sudan has lengthy borders with nine countries, namely: it is bordered by Egypt to the north, Libya to the northwest, Eritrea and Ethiopia to the east, Kenya and Uganda to the south, Democratic Republic of Congo and Central African Republic to the southwest and Chad to the west, the Red Sea to the northeast separates Sudan from the Kingdom of Saudi Arabia

${ }^{3}$ See Sudan Central Bureau of Statistics Statistical Year Book (2008), “General Information” pp. XI-XII.
} 
military governments. For instance, the first civilian government after independence (1956-1958) was overthrown in 1958 by the Abbud Military Government (1958-1964), the second elected civilian government (1964-1969) was overthrown in 1969 and by the Nimeiri Military Government (1969-1985) and once again the third elected civilian government (1985-1989) was overthrown in 1989 by Al Bashir Military Government (1989-2005). Since the signing and implementation of the Comprehensive Peace Agreement (CPA) in January 2005 the Sudan is ruled by the Government of National Unity (GNU) which represents a power-sharing government between the National Congress Party (NCP) of the north and Sudan People's Liberation Movement (SPLM) of the south. As for government and politics, the politics of Sudan takes place, in the framework of a federal presidential representative democratic republic, the judiciary is independent and obtained by the Constitutional Court and the legislative power is vested in both the government and in the two chambers, the National Assembly (lower) and the Council of States (upper), the bicameral National Legislature is the official Sudanese parliament consists of 500 appointed members. ${ }^{4}$

The record of the political context in Sudan is characterized by a long history of serious political instability, continuing civil wars and complex conflict between the north and the south that first occurred even before Sudan gained its independence and continued after gaining its independence in 1956. For instance, over the period (1955-2005), Sudan has suffered from instability and two civil wars between the north and the south. Sudan finally ended the second civil war by signing the Comprehensive Peace Agreement (CPA) ${ }^{5}$ and by adopting a new constitution in 2005. ${ }^{6}$ The implementation of the CPA implies several important agreed issues, which included the formation of the Government of National Unity (GNU) in 2005, which represents a power-sharing government between the National Congress Party (NCP) of the north and Sudan People's Liberation Movement (SPLM) of the south. Moreover, the implementation of the CPA implies several other important agreed issues, which included the establishment of an interim transitional period of autonomous rule for the South for six years (2005-2011) and it followed by the self-determination for the southern Sudan and a referendum in Southern Sudan to decide on unity or secession from the north (that was just held in January 2011). Now near the end of the Interim Period, both the north and south have seen significant benefits from the peace though significant political economy risks remain. While national income has increased dramatically, the post-conflict environment continues to be characterized by difficult political and security situations and internal and external tensions. Internally, the relations between north and south remain tense, the performance of Government of National Unity (GoNU) has often

\footnotetext{
${ }^{4}$ Sudan is divided into twenty-six states which in turn are subdivided into 87 districts; the ten states in Southern Sudan are subdivided into 84 counties. The states are: Al Jazirah, Al Qadarif, Blue Nile, Central Equatoria, East Equatoria, Jonglei, Kassala, Khartoum, Lakes, North Bahr al Ghazal, North Darfur, North Kurdufan, Northern, Red Sea, River Nile, Sennar, South Darfur, South Kurdufan, Unity, Upper Nile, Warab, West Bahr al Ghazal, West Darfur, West Equatoria and White Nile.

${ }^{5}$ The CPA was signed on January 9, 2005, ending conflict between the Government of Sudan and the Sudan People's Liberation Movement/Sudan People's Liberation (SPLM) Army.
} 
constrained by and suffered from the inconsistency and disagreement due to the continuous dispute and conflict between the ruling NCP and the SPLM. Externally, Sudan remains at the center of intense international pressure over the civilian impact of continued conflict in the Darfur region of the country, which is so far unresolved. These issues are reminders that the political economy context in Sudan will remain complex and uncertain, even for a post-conflict country. ${ }^{7}$ So far Sudan is still suffering from political instability due to escalation and continuation of conflict in the country. In our view this political instability may lead to serious implications in the short and long run economic growth and development in Sudan. Moreover, the unbalanced development in Sudan, with a large regional disparity remains a potential source for conflict and political instability. Furthermore, from institutional perspective, Sudan suffered from the lack of sound and systematic institutional setting and the lack of commitment to implementation of long run sustainable and balanced economic and development plans and strategies. In our view the interaction between these important endogenous political, economic and institutional factors most probably have not only been important for the interpretation of the root causes of the north-south conflict but most probably also important for the interpretation of the root causes of continued low standard of economic development in Sudan for a long time period. This implies that the interaction between these political, economic and institutional factors together have unfortunately continued to contribute to a low standard of economic development in Sudan as we explain below in the next section.

\section{2. General socio-economic characteristics of Sudan}

As for the general socio-economic characteristics of the Sudan, Table 1 below explains the demographic structure and the major socio-economic characteristics for Sudan. Table 1 below shows the considerable diversity between Sudan, African and Arab countries and the world regions in terms of population, standard of economic development as measured by GDP per capita and human development index. Sudan generally has higher population number coupled with lower standard of economic development. The World Bank classification of economies puts Sudan among the lower medium-income economies. Moreover, the UNDP HDI shows that the average GDP per capita for Sudan falls within the world medium-income bracket and is, on average, lower than for those of the world and Arab countries. This also holds for other HDI components: average life expectancy, literacy rate and combined enrolment ratios. Moreover, according to UNDP indicators and estimates from International Monetary Fund's World Economic Outlook (IMF 2002), as in most other typically poor developing countries Sudan continued to suffer from widespread and high rates of poverty and unemployment.

\footnotetext{
${ }^{6}$ See: http://en.wikipedia.org/wiki/Sudan: Accessed in June 01 ${ }^{\text {st }}$, 2010

${ }^{7}$ See WB-DTIS, (2008): p.1.
} 
Table 1- General socio-economic characteristics of the Sudan ${ }^{8}$

\begin{tabular}{|c|c|c|c|c|c|c|}
\hline Country & $\begin{array}{l}\text { Population }{ }^{a b} \text { (millions) } \\
(2007-2008)\end{array}$ & $\begin{array}{l}\text { GDP } \quad \text { per } \\
\left(\text { PPP }^{\mathrm{C}} \text { US\$) }\right.\end{array}$ & $\begin{array}{l}\text { Human } \\
\text { Development } \\
\text { Index }^{a}(\%)\end{array}$ & $\begin{array}{l}\text { Life } \\
\text { Expectancy }^{a} \\
\text { (years) }\end{array}$ & $\begin{array}{l}\text { Adult Literacy } \\
\text { Rate }^{a} \text { (\% aged } \\
15 \text { and above) }\end{array}$ & $\begin{array}{l}\text { Combined } \\
\text { enrolment } \\
\text { ratio }^{a}(\%)\end{array}$ \\
\hline & 2007 & 2007 & 2007 & 2007 & $1999-2007$ & 2007 \\
\hline Sudan $^{b}$ & 39.2 & 2086 & 0.531 & 57.9 & 60.9 & 39.9 \\
\hline Africa & 638.6 & 2,729 & 0.547 & 53.9 & 63.3 & 55.9 \\
\hline Asia & 3178.8 & 5,837 & 0.724 & 68.8 & 82.1 & 64.5 \\
\hline Europe & 720.8 & 24,775 & 0.902 & 74.9 & 99.2 & 88.2 \\
\hline Latin America and the Caribbean & 437.5 & 10,077 & 0.821 & 73.4 & 91.2 & 83.4 \\
\hline Northern America & 282.7 &.. & 0.952 & 79.2 & 96.5 &.. \\
\hline Oceania & 26.9 & .. & 0.900 & 76.4 & 93.0 & .. \\
\hline Arab States & 229.3 & 8,202 & 0.719 & 68.5 & 71.2 & 66.2 \\
\hline GCC & 23.1 & 30,415 & 0.868 & 74.0 & 86.8 & 77.0 \\
\hline Central and Eastern Europe and the CIS & 468.1 & 12,185 & 0.821 & 69.7 & 97.6 & 79.5 \\
\hline CIS & 280.9 & 10,487 & 0.802 & 67.0 & 99.4 & 81.1 \\
\hline East Asia and the Pacific & 1658.5 & 5,733 & 0.770 & 72.2 & 92.7 & 69.3 \\
\hline Latin America and the Caribbean & 437.5 & 10,077 & 0.821 & 73.4 & 91.2 & 83.4 \\
\hline South Asia & 1200.0 & 2,905 & 0.612 & 64.1 & 64.2 & 58.0 \\
\hline Sub-Saharan Africa & 483.1 & 2,031 & 0.514 & 51.5 & 62.9 & 53.5 \\
\hline OECD & 1048.6 & 32,647 & 0.932 & 79.0 &.. & 89.1 \\
\hline European Union (EU27) & 471.6 & 29956 & 0.937 & 79 &.. & 91 \\
\hline High human development & 784.2 & 12,569 & 0.833 & 72.4 & 94.1 & 82.4 \\
\hline Medium human development & 3388.5 & 3,963 & 0.686 & 66.9 & 80.0 & 63.3 \\
\hline Low human development & 240.2 & 862 & 0.423 & 51.0 & 47.7 & 47.6 \\
\hline World & 5290.5 & 9,972 & 0.753 & 67.5 & 83.9 & 67.5 \\
\hline
\end{tabular}

One stylised fact on the case of Sudan is that Sudan is large by regional standards, but its economy is small in global terms. According to the World Bank and United Nations classification and definition, Sudan is classified among Sub-Saharan African countries and among the poor and low income and highly indebted countries. For instance, the UNDP and the World Bank shows the low GDP per capita income in Sudan which is in excess of only least developing countries, but less than all other World regions. Despite the high and increasing inflow of Foreign Direct Investment (FDI) to Sudan, but different from other World regions, Sudan suffered from the high increase in debt services both as percentage of GDP and as percentage of exports over the period (1990-2005). That was most probably because like most African countries, Sudan's economy has relied heavily on a large influx of foreign aid from different sources; Sudan is among the top ten recipients of gross Official Development Assistance during (1990-2007) - see Table 2 below

\begin{tabular}{|c|c|c|c|c|c|c|c|c|c|c|c|c|c|}
\hline \multirow[t]{3}{*}{ Country and Regions } & \multirow{3}{*}{$\begin{array}{l}\text { GDP } \\
\text { Per } \\
\text { capita } \\
2005 \\
\end{array}$} & \multicolumn{4}{|c|}{$\begin{array}{l}\text { Official development assistance } \\
\text { (ODA) received (net disbursements) }\end{array}$} & \multirow{2}{*}{\multicolumn{2}{|c|}{$\begin{array}{l}\text { FDI } \\
\% \text { GDP }\end{array}$}} & \multirow{2}{*}{\multicolumn{2}{|c|}{$\begin{array}{l}\text { Private Capital } \\
\text { \%GDP }\end{array}$}} & \multicolumn{4}{|c|}{ Debt services } \\
\hline & & \multirow{2}{*}{$\begin{array}{l}\text { Total } \\
\text { (US\$ } \\
\text { million) } \\
2005\end{array}$} & \multirow{2}{*}{$\begin{array}{l}\begin{array}{l}\text { Per } \\
\text { capita } \\
\text { (US\$) }\end{array} \\
2005 \\
\end{array}$} & \multicolumn{2}{|c|}{ As \% of GDP } & & & & & \multicolumn{2}{|c|}{ \% GDP } & \multicolumn{2}{|c|}{ \% Exports } \\
\hline & & & & 1990 & 2005 & 1990 & 2005 & \multicolumn{2}{|l|}{1990} & 1990 & 2005 & 1990 & 2005 \\
\hline Sudan & 2,083 & $1,828.6$ & 50.5 & 6.2 & 6.6 & -0.2 & 8.4 & 0.0 & 0.2 & 0.4 & 1.4 & 8.7 & 6.5 \\
\hline Developing countries & 5,282 & $86,043.0$ & 16.5 & 1.4 & 0.9 & 0.9 & 2.7 & 0.5 & 1.5 & 4.4 & 4.6 & 15.6 & 13.0 \\
\hline LDCs & 1,499 & $25,979.5$ & 33.9 & 11.8 & 9.3 & 0.3 & 2.6 & 0.5 & 0.8 & 3.0 & 2.3 & 16.9 & 7.0 \\
\hline Arab countries & 6,716 & $29,612.0$ & 94.3 & 2.9 & 3.0 & 0.5 & 1.5 & n.a. & 1.8 & n.a. & n.a. & 21.3 & 8.5 \\
\hline Asia and the Pacific & 6,604 & $9,541.6$ & 4.9 & 0.8 & 0.2 & 1.7 & 3.4 & n.a. & n.a. & n.a. & n.a. & 9.9 & 2.6 \\
\hline Latin America and the Caribbean & 8,417 & $6,249.5$ & 11.3 & 0.5 & 0.3 & 0.8 & 2.9 & 0.5 & 1.2 & 4.0 & 6.6 & 23.7 & 22.7 \\
\hline South Asia & 3,416 & $9,937.5$ & 6.3 & 1.2 & 0.8 & n.a. & 0.8 & 0.3 & 1.2 & 2.3 & 2.6 & 22.8 & 15.4 \\
\hline Sub-Saharan Africa & 1,998 & $30,167.7$ & 41.7 & 5.7 & 5.1 & 0.4 & 2.4 & 0.3 & 1.7 & n.a. & n.a. & 10.5 & 5.8 \\
\hline Central and Eastern Europe & 9,527 & $5,299.4$ & 13.1 & n.a. & 0.3 & n.a. & 4.0 & n.a. & 4.4 & n.a. & n.a. & n.a. & n.a. \\
\hline OECD & 29,197 & 759.4 & n.a. & n.a. & n.a. & 1.0 & 1.6 & n.a. & n.a. & n.a. & n.a. & n.a. & n.a. \\
\hline High Income countries & 33,082 & n.a. & n.a. & n.a. & n.a. & 1.0 & 1.6 & n.a. & n.a. & n.a. & n.a. & n.a. & n.a. \\
\hline Middle Income countries & 7,416 & $42,242.2$ & 13.7 & 0.7 & 1.3 & 0.9 & 3.1 & 0.4 & 2.2 & 4.5 & 5.5 & 20.3 & 14.3 \\
\hline Low Income countries & 2,531 & $44,123.0$ & 18.2 & 4.1 & 3.2 & 0.4 & 1.4 & 0.3 & 1.0 & 3.7 & 3.1 & 27.1 & 13.7 \\
\hline World & 9,543 & $106,372.9$ & 16.3 & 0.3 & 0.2 & 1.0 & 1.9 & n.a. & 2.0 & n.a. & 5.1 & n.a. & n.a. \\
\hline
\end{tabular}

\footnotetext{
8 The World Bank and United Nations Development Programme (UNDP) Human Development Report classify world countries differently according to income level. We use the World Bank classification of economies that puts Sudan in the lower middleincome category or group.
} 
As for the structure of the economy, since long, the structure of Sudan economy is characterised by small share of industry, notably, manufacturing; high share of agriculture and services sectors in GDP and employment and dependence on primary exports, mainly, dependence on the exports of agricultural products- see Table 3 below. Agricultural sector remains Sudan's most important sector, employing $80 \%$ of the workforce and contributing 39\% of GDP. According to World Development Indicator database (WDI 2005) the structure of Sudan economy shows the importance of both the agricultural $(71 \%, 39 \%)$ and services sectors $(21 \%, 43 \%)$ compared to the industrial sector $(9 \%, 18 \%)$ in terms of both the share in total employment (1990) and value added as a percentage of GDP (2002) respectively. ${ }^{9}$ The share of agriculture in GDP increased from $30.3 \%$ in 1990 to $49.8 \%$ in 1999 and then declined to $31.1 \%$ in 2009; the share of the services in GDP declined from 54.4\% in 1990 to $34.4 \%$ in 1999 and then increased to $45.0 \%$ in 2009; the share of industry in GDP increased from $15.4 \%$ in 1990 to $15.8 \%$ in 1999 and then increased to $23.9 \%$ in 2009- see Table 3.

In 1999, Sudan began exporting crude oil and in the last quarter of 1999, recorded its first trade surplus. Increased oil production revived light industry, and expanded export processing zones helped sustain GDP growth at 6.1\% in 2003. These gains, along with improvements to monetary policy, have stabilized the exchange rate. In recent years after the exploitation of oil Sudan economy become increasingly dependent on oil exports, and the economy turned into an oil dependent economy. Currently oil is Sudan's main export, and the production is increasing dramatically. With rising oil revenues the Sudanese economy is booming, with a growth rate of about $9 \%$ in 2007. Sudan's non-oil exports are diversified across a wide range of products, but most of these exports are concentrated in few countries (WB-DTIS, 2008). Sudan's real growth of trade of $25 \%$ in 2007 represents the second highest growth in the world for that year among all countries (WB-DTIS, 2008). In recent years the increasing dependence on oil leads to sound economic growth. Consequently, Sudan's real economic growth averaged about 9\% during (2005-2006), putting Sudan among the fastest growing economies in Africa (WB, 2008). According to the World Bank (2008) Sudan is one of the newest significant oil producing countries in the World; Sudan is the third largest oil producers in Sub Saharan Africa (SSA) behind Nigeria and Angola. As a result, in recent years, the structure of the Sudanese economy has shifted over time, from predominantly reliant on agriculture for growth and exports, to its current reliance on the oil sector (WB, 2008). But while the increasing dependence on oil leads to several positive impacts it also lead to several negative impacts and increasing debate for and against the incidence of the Dutch Disease in Sudan economy.

\footnotetext{
${ }^{9}$ See for instance, the World Development Indicator database: WDI (2005).
} 
Table (3) - The Performance, Structure and Structural Change in Sudan Economy (1990-2009)

\begin{tabular}{|c|c|c|c|c|c|c|c|c|c|c|c|c|c|}
\hline \multirow[t]{2}{*}{ Year } & \multirow[t]{2}{*}{ GDP } & \multirow[t]{2}{*}{$\begin{array}{l}\text { GDP } \\
\text { Growth } \\
\text { Rate }\end{array}$} & \multirow[t]{2}{*}{$\begin{array}{l}\text { GDP Per } \\
\text { capita }\end{array}$} & \multirow[t]{2}{*}{$\begin{array}{l}\text { GDP Per } \\
\text { capita Growth } \\
\text { Rate }\end{array}$} & \multirow[t]{2}{*}{$\begin{array}{l}\text { Inflati } \\
\text { on } \\
\text { Rate } \\
\end{array}$} & \multirow[t]{2}{*}{$\begin{array}{l}\text { Exchange } \\
\text { Rate }\end{array}$} & \multirow[t]{2}{*}{$\begin{array}{l}\text { Balance of } \\
\text { payment }\end{array}$} & \multicolumn{3}{|c|}{ Balance of Trade } & \multicolumn{3}{|c|}{$\begin{array}{l}\text { Structure of Sudan Economy (share of } \\
\text { sectors in GDP) }\end{array}$} \\
\hline & & & & & & & & Exports & Imports & Balance & Agriculture & Industry & $\begin{array}{l}\text { Services } \\
\end{array}$ \\
\hline 1990 & 244.7 & 5.4 & 47.7 & 0 & 41 & 0.45 & -76.1 & 374 & 618.4 & -244.4 & 30.3 & 15.4 & 54.4 \\
\hline 1991 & 276.8 & 7.5 & 81 & 69.8 & 62.7 & 0.69 & -101.3 & 308.7 & 890.3 & -581.6 & 28.7 & 17.6 & 53.9 \\
\hline 1992 & 4327.8 & 6.5 & 17.2 & -78.7 & 105.4 & 9.7 & $\begin{array}{l}-58.1 \\
\end{array}$ & 319.3 & 820.9 & -501.6 & 33.7 & 17.1 & 49.1 \\
\hline 1993 & 5862.1 & 4.5 & 37.6 & 118.4 & 115 & 16.1 & 37.7 & 417.3 & 944.9 & -527.6 & 37.9 & 17.4 & 44.5 \\
\hline 1994 & 6351.2 & 1 & 72.5 & 92.7 & 96.3 & 29.6 & 17.9 & 535.6 & 1059.6 & -524 & 40.1 & 16.4 & 43.5 \\
\hline 1995 & 9880.7 & 5.9 & 151.7 & 109.4 & 177.2 & 55.9 & -58.1 & 555.7 & 1184.8 & -629.1 & 43.1 & 15.8 & 41.1 \\
\hline 1996 & 8259.3 & 5.9 & 375.9 & 147.7 & 76.3 & 125 & -63.9 & 620.3 & 1504.5 & -884.2 & 44.9 & 14.5 & 40.6 \\
\hline 1997 & 10684.8 & 6.3 & 563.7 & 50 & 52.6 & 156.9 & -36.2 & 594.2 & 1421.9 & -827.7 & 47.6 & 15.1 & 37.2 \\
\hline 1998 & 11513.7 & 6.4 & 743.7 & 31.9 & 28.2 & 198.8 & 25.1 & 595.7 & 1732.2 & -1136.5 & 48.6 & 15 & 36.2 \\
\hline 1999 & 10325 & 6.7 & 892.3 & 20 & 6.4 & 252 & 111.5 & 780.1 & 1256.2 & -476.1 & 49.8 & 15.8 & 34.4 \\
\hline 2000 & 11242.2 & 8 & $1,083.10$ & 21.4 & 8.5 & 257.2 & 81.5 & 1807 & 1553 & 254 & 46.4 & 21.4 & 32.2 \\
\hline 2001 & 12596.5 & 6.7 & $1,274.00$ & 17.6 & 4.8 & 257.3 & -90.04 & 1547 & 1457 & 90 & 45.6 & 22.8 & 31.6 \\
\hline 2002 & 3924 & 6.5 & $1,457.40$ & 14.4 & 8.3 & 236 & 198.72 & 1949 & 2179.22 & -230.11 & 46 & 23.2 & 30.9 \\
\hline 2003 & 4549 & 6 & $1,656.40$ & 13.7 & 7.7 & 261 & 422.6 & 2542.2 & 2536.1 & 6.07 & 44 & 24.1 & 30.3 \\
\hline 2004 & 5278 & 7.2 & $1,991.20$ & 20.2 & 8.5 & 258 & 730.2 & 3777.75 & 3586.18 & 191.57 & 40 & 28.0 & 32.0 \\
\hline 2005 & 6283 & 8 & $2,421.20$ & 21.6 & 8.5 & 245.6 & 530.5 & 4824.3 & $5,946.0$ & -1121.7 & 39.0 & 28.0 & 32.0 \\
\hline 2006 & $22,217.0$ & 10.0 & $2,719.00$ & 12.3 & 7.2 & 2.0248 & -208.6 & $5,656.6$ & $7,104.0$ & $-1,448.1$ & 36.8 & 27.5 & 35.7 \\
\hline 2007 & 22,21 & 10.5 & $3,059.20$ & 12.5 & 8.1 & 2.0308 & -282 & $8,879.2$ & $7,722.4$ & $1,156.8$ & 35.3 & 30.6 & 34.1 \\
\hline 2008 & 26.03 & 7,8 & $3,262.60$ & 6.6 & 14,3 & 2,09 & 21.1 & $11,670.5$ & $8,229.4$ & $3,441.1$ & 29.3 & 29.2 & 41.5 \\
\hline 2009 & 27.63 & 6.1 & & & 11,2 & 2,32 & -502.2 & $7,833.7$ & $8,528.0$ & -694.3 & 31.1 & 23.9 & 45.0 \\
\hline
\end{tabular}

statistics: Sudan statistical year book: Sudan statistics 1990- 2008: pp. 39-43.

Figures 1- 4 - Total and Growth Rates of GDP and GDP Per Capita in Sudan during (1990-2008) (Millions Sudanese pounds) and (\%)
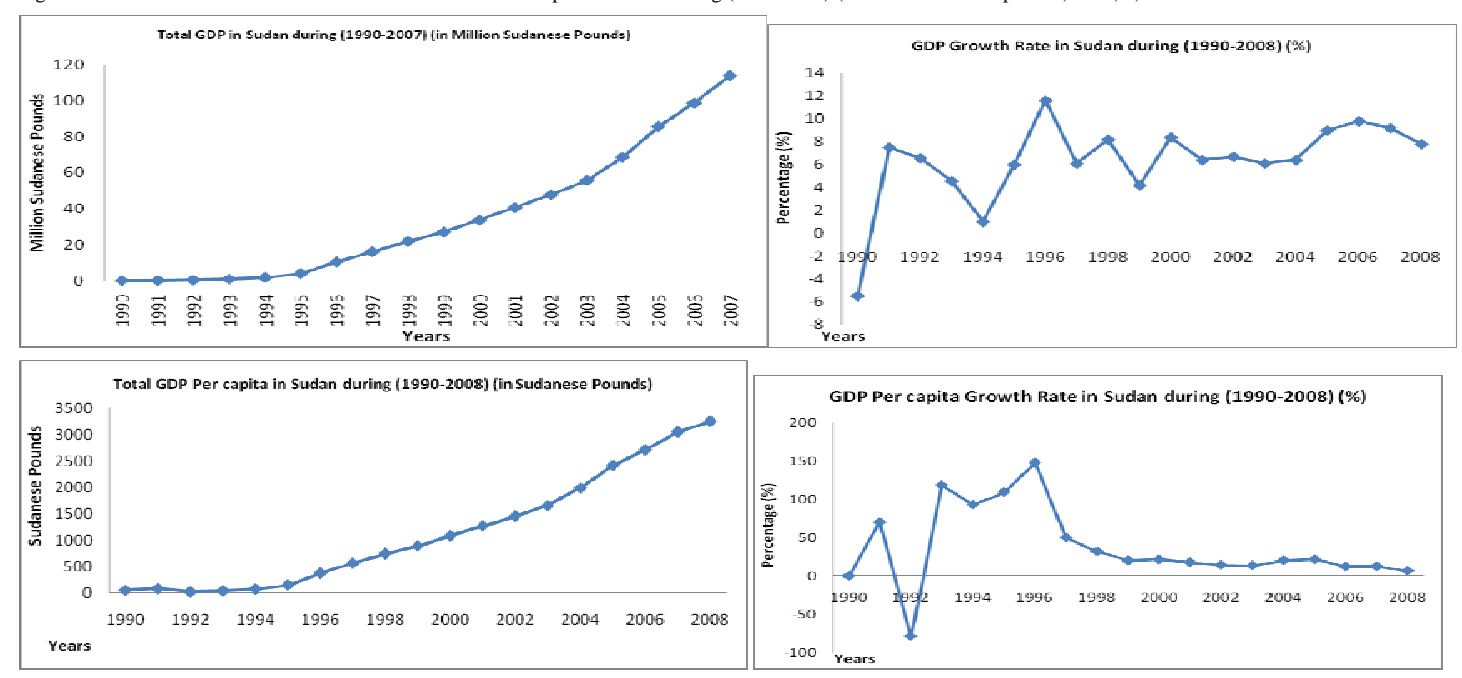

Source: Adapted from Sudan Central Bureau of Statistics: Sudan Ministry of the Cabinet- central bureau of statistics: Sudan statistical year book: Sudan statistics 1990- 2008: pp. $39-43$

As for the economic reform, since gaining its independence in 1956 and over the past decades, Sudan economy suffered from continuing macroeconomic instability and crisis, low GDP per capita income, presence of high rates of poverty, unemployment, inequalities, weak economic performance and an uneven growth until recent years. The imperative of reforming macroeconomic management in Sudan dates back to the 1970s and 1980s, when the first wave of reforms was undertaken during 1978-1984. A new wave of intensive reforms was initiated, culminating in the adjustment policies of the medium-term National Economic Salvation Programme (NESP) for 1990/91-1992/93, which was merged into the Comprehensive National Plan (CNP) of 1992-2002. The broad objective of NESP was the revitalization of the Sudanese economy. The government reform efforts emphasized four aspects in particular ${ }^{10}$ : (a) restoring macroeconomic stability and combating runaway inflation through tough fiscal and monetary policies; stabilization of the foreign exchange rate through managed floating; (b) emphasizing 
market-oriented economic activity, liberalization, abolition of controls and deregulation of imports, foreign exchange, and prices; (c) limiting the role of the state through privatizing public-sector enterprises and extending the role of the private sector to all activities including health, education and utilities; and (d) Encouraging saving by reforming the financial system and banking sector and introducing new saving instruments. ${ }^{11}$ Since the late 1990s, notably, 1997, due to implementation of macroeconomic reforms policies recommended by the IMF, Sudan then finally achieved great improvement in the performance of most macroeconomic indicators, impressive real economic growth and rapid increase in GDP and GDP per capita incomes- see Table 3 and Figures 1-4 above. Consequently, due to this economic reform along with the positive contribution of oil in Sudan economy since 1999, the Sudan turned from a low income economy into a lower medium income economy according to the World Bank classification in the recent years

According to UNDP (2010), prior to the global financial crisis, the Sudanese economy has been one of the fastest growing in the world despite the USA sanctions. The Nominal Gross Domestic Product (GDP) grew from US \$ 9.9 billion (IMF 1980) to US \$ 57.9 billion. ${ }^{12}$ The GDP growth is expected to be around US\$ 52.2 billion in 2009. In recent years, growth rates increased from $7.1 \%$ (2003) to $10.2 \%$ (2007). ${ }^{13}$ However, the global financial crisis and related shock in 2008 and 2009 resulted in low global oil prices, stagnating domestic oil production and caused reduction in GDP growth rate that dropped from 10.5\% in 2007 to $7.8 \%$ and $5 \%$ in 2008 and 2009 respectively-see Table 3 and Figures 1-4 above. A recent IMF report ranked Sudan as one of the most vulnerable low -income countries in the global financial crisis due to its high vulnerability to trade, aid and remittances shocks. IMF adjusted 2009 GDP growth projections for Sudan downwards by 6.7\%, representing the fourth largest adjustment of the 71 low-income countries assessed ${ }^{14}$. Past growth was not sufficiently broad-based, investments and services are concentrated in and around Khartoum state and to a lesser extent Juba, the capital of southern Sudan. The significant disparities between urban and rural areas and between regions contributed to growing inequalities and an increasing urban informal sector accounting for more than $60 \%$ of GDP. This state of affairs has been encouraging a rural-urban migration that might weaken the agricultural productivity, deepen poverty in urban and rural areas (and unemployment in urban area). ${ }^{15}$

Despite the recent impressive real growth and rapid increase in per capita incomes following oil exploitation but emerging vulnerabilities and little progress in social indicators still

\footnotetext{
${ }^{10}$ See for instance, the World Bank, (2003), Vol. I: 44.

${ }^{11}$ See the United Nations Development Programme UNDP in Sudan (2006) "Macroeconomic Policies for Poverty Reduction: The Case of Sudan," Khartoum, Sudan, 2006.

${ }^{12}$ See IMF projection for 2008

${ }^{13}$ See IMF Projection for 2008 and IMF First Review of Performance Under the 2007-2008 Staff-Monitored Program, June 2008, p.2.

${ }^{14}$ See IMF Report on the implications of the Global Financial Crisis for Low-Income Countries, March 2009, p.50

${ }^{15}$ See the UN Millennium Development Goals in Sudan: http://www.sd.undp.org/mdg_sudan.htm, accessed on June 01, 2010.
} 
exist and Sudan still faces formidable economic problems, as yet it is one of the least developed countries in the world and it must rise from a very low level of per capita output. This is evidence from UNDP-Human Development Indicators (2007) and (2009) which indicate that Sudan has scored medium in human development in the last few years, it is classified amongst the bottom of developing countries in terms of HDI, as it ranked 147 and 150 out of 177 developing countries in 2007 and 2009 respectively. ${ }^{16}$ Moreover, as for progress and the status of Millennium Development Goals (MDGs) in Sudan, according to UNDP (2010), while progress has been made towards several of the Millennium Development Goals (MDGs), such as in the area of education, infant and child mortality, access to water and sanitation, Sudan's performance against the MDG indicators demonstrates big inequalities with respect to gender, rural-urban residence, and at the regional and sub-regional level- see Table 4 below. ${ }^{17}$ A rapid acceleration of development efforts is needed if Sudan is to achieve the MDGs by 2015, especially in waraffected areas. Estimated poverty rates remain high with up to 90 percent in Southern Sudan and in the so-called Protocol Areas which are Southern Kordofan, Blue Nile and Abyei. In addition, barely 1 in 5 children complete primary school; clean water is available to only 1 in 4 in some regions and maternal mortality ratio in Southern Sudan is among the highest in the world. Opportunities from economic growth as well as a transition from a humanitarian context to recovery and development are, however, apparent. According to UNDP (2010) due to the global shock, especially regarding oil prices and international lending, but also with respect to expected reductions in FDI, remittances and aid, Sudan is about to face significant financing shortages for its 2009 federal budget, and will have to drastically reduce its public spending, affecting government's capacity to invest in MDGs and poverty reduction. Poverty is widespread in Sudan, for instance, UNDP’s 2008 Human Development Report HDR ranked the country 147th among 177 countries compared to position 141 in 2006. According to a 2007 joint World BankUNDP mission, about $60-75 \%$ of the population in the North and 90 per cent in the South are estimated to be living below the poverty line of less than US $\$ 1$ a day. The hardest hit by poverty are people living in rural areas, in particular women and internally displaced people who constitute about $12 \%$ of the population. The lack of formal schooling and high levels of youth unemployment is turning the potential of the young generation from an asset into a challenge for the future. ${ }^{18}$ The low human development indicators implies that Sudan continued to fall below

\footnotetext{
${ }^{16}$ See http://en.wikipedia.org/wiki/Sudan Accessed June 01 ${ }^{\text {st }}, 2010$

17 The Millennium Declaration and adoption of the United Nations Millennium Development Goals (MDGs) in September 2000 implies commitment towards achievement of the eight MDGs by 2015. The Millennium Development Goals are: (1) Eradicate extreme poverty and hunger: Halve, between 1990 and 2015, the proportion of people whose income is less than one dollar a day, and halve, between 1990 and 2015, the proportion of people who suffer from hunger. (2) Achieve universal primary education: Ensure that, by 2015, children everywhere, boys and girls alike, will be able to complete a full course of primary schooling. (3) Promote gender equality and empower women: Eliminate gender disparity in primary and secondary education, preferably by 2005, and in all levels of education no later than 2015. (4) Reduce child mortality: Reduce by two thirds, between 1990 and 2015 , the under-five mortality rate. (5) Improve maternal health: Reduce by three-quarters, between 1990 and 2015, the maternal mortality ratio. (6) Combat HIV/AIDS, malaria and other diseases. (7) Ensure environmental sustainability and (8) Develop a global partnership for development. (See for instance, the UND-HDR).

${ }^{18}$ See The UN Millennium Development Goals in Sudan: http://www.sd.undp.org/mdg_sudan.htm accessed on June 01, 2010
} 
the Arab states and world average level over the past three decades, for instance, the trend of human development index over the period (1980-2010), implies that Sudan's level in 2010 fall s below the Arab states and world average level not only in 2010 but also in 1980- see Figure 5 below.

Table (4) - The status of MDGs in Sudan in 2008

\begin{tabular}{|c|c|c|c|c|c|}
\hline MDGs / Indicators & Indicators & $\begin{array}{l}\text { Northern } \\
\text { Sudan }\end{array}$ & $\begin{array}{l}2015 \\
\text { Target }\end{array}$ & $\begin{array}{l}\text { Southern } \\
\text { Sudan }\end{array}$ & $\begin{array}{l}2015 \\
\text { Target }\end{array}$ \\
\hline \multirow{3}{*}{$\begin{array}{l}\text { MDG } 1 \text { Eradicate } \\
\text { Extreme Poverty and } \\
\text { Hunger }\end{array}$} & Estimated poverty incidence (\% of total population) * & $50 \%$ & $45 \%$ & $90 \%$ & $45 \%$ \\
\hline & $\begin{array}{l}\text { Prevalence of child malnutrition (underweight for age; \% } \\
\text { under 5)* }\end{array}$ & $35 \%$ & $16 \%$ & $48 \%$ & $24 \%$ \\
\hline & $\begin{array}{l}\begin{array}{l}\text { Prevalence of acute child } \\
\text { (underweight for weight; \% under 5) }\end{array} \\
\text { (undnutrition }\end{array}$ & $16 \%$ & $8 \%$ & $21 \%$ & $11 \%$ \\
\hline \multirow{3}{*}{$\begin{array}{ll}\text { MDG 2 } & \text { Achieve } \\
\text { Universal } & \text { Primary } \\
\text { Education } & \end{array}$} & Gross primary enrolment ratio*** & $62 \%$ & $100 \%$ & $20 \%$ & $100 \%$ \\
\hline & Percentage of cohort completing primary school $* * *$ & $21 \%$ & $100 \%$ & $2 \%$ & $100 \%$ \\
\hline & Adult literacy rate ** & $60-70 \%$ & $25 \% 1$ & $\begin{array}{l}\text { (North and } \\
\text { South) }\end{array}$ & \\
\hline \multirow{3}{*}{$\begin{array}{llr}\text { MDG } & 3 & \text { Promote } \\
\text { Gender Equality and } & \text { Empower Women }\end{array}$} & Ratio girls to boys in primary education $* * *$ & $88 \%$ & $100 \%$ & $36 \%$ & $100 \%$ \\
\hline & Women’s literacy rate & $62 \%$ & - & $12 \%$ & - \\
\hline & $\begin{array}{l}\text { Percentage of women in National Assembly/Council of } \\
\text { States }\end{array}$ & $19 \%$ & - & $4 \%$ & $25 \%$ \\
\hline \multirow{3}{*}{$\begin{array}{l}\text { MDG } 4 \text { Reduce Child } \\
\text { Mortality }\end{array}$} & Under-5 mortality rate (per 1,000$)^{*}$ & 105 & 35 & 126 & 83 \\
\hline & Infant mortality rate (per 1,000 live births)* & 70 & - & 89 & - \\
\hline & One-year-olds immunized against measles $* * *$ & $78 \%$ & - & $20.2 \%$ & - \\
\hline \multirow{2}{*}{$\begin{array}{lll}\text { MDG } & 5 & \text { Improve } \\
\text { Maternal Health }\end{array}$} & Maternal mortality ratio (per 100,000 live births) & 638 & 127 & 2,054 & 425 \\
\hline & Birth attended by skilled health staff * & $57 \%$ & $90 \%$ & $5 \%$ & $90 \%$ \\
\hline \multirow{4}{*}{$\begin{array}{l}\text { MDG } 6 \text { Combat HIV } \\
\text { Aids, Malaria and other } \\
\text { diseases }\end{array}$} & Contraceptive prevalence (\% of women ages $15-49) * * *$ & $7 \%$ & - & $<1 \%$ & - \\
\hline & HIV Prevalence (\% adults ages $15-49)^{*}$ & $1.6 \%$ & - & $2.3 \%$ & - \\
\hline & Incidence of TB (per 100,000 per year)*** & 90 & - & 325 & - \\
\hline & Children under 5 with fever treated with anti-malarial (\%) & $54.2 \% *$ & - & $36 \% * * *$ & - \\
\hline \multirow{2}{*}{$\begin{array}{l}\text { MDG } 7 \text { Integrate } \\
\text { principles } \\
\text { sustainable } \\
\text { development of } \\
\text { country policies and } \\
\text { programmes; reverse } \\
\text { loss of environmental } \\
\text { resources } \\
\end{array}$} & $\begin{array}{l}\begin{array}{l}\text { Access to improved drinking } \\
\text { population })^{*}\end{array} \\
\end{array}$ & $58.7 \%$ & $85 \%$ & $48.3 \%$ & $75 \%$ \\
\hline & Access to improved sanitation (\% of population) * & $39.9 \%$ & $67 \%$ & $6.4 \%$ & $53 \%$ \\
\hline $\begin{array}{l}\text { MDG } 8 \text { Develop a } \\
\text { Global Partnership for } \\
\text { development }\end{array}$ & \multicolumn{5}{|c|}{$\begin{array}{l}\text { Progress in Sudan } \\
\text { - The Darfur crisis is currently preventing progress in global partnership, } \\
\text { - To achieve the MDGs, Sudan will need to make significant investments to build the capacity of human resources, } \\
\text { infrastructure and institutions as well as to mobilize resources to bridge the financial gap. } \\
\text { - It is necessary that a continuous and sustained effort by the Sudanese people, its governments, and the } \\
\text { international community is exerted to achieve MDG8. }\end{array}$} \\
\hline
\end{tabular}

Figure (5) - Human Development Index: Trends in (1980 - 2010) in Sudan Compared to Arab States and World

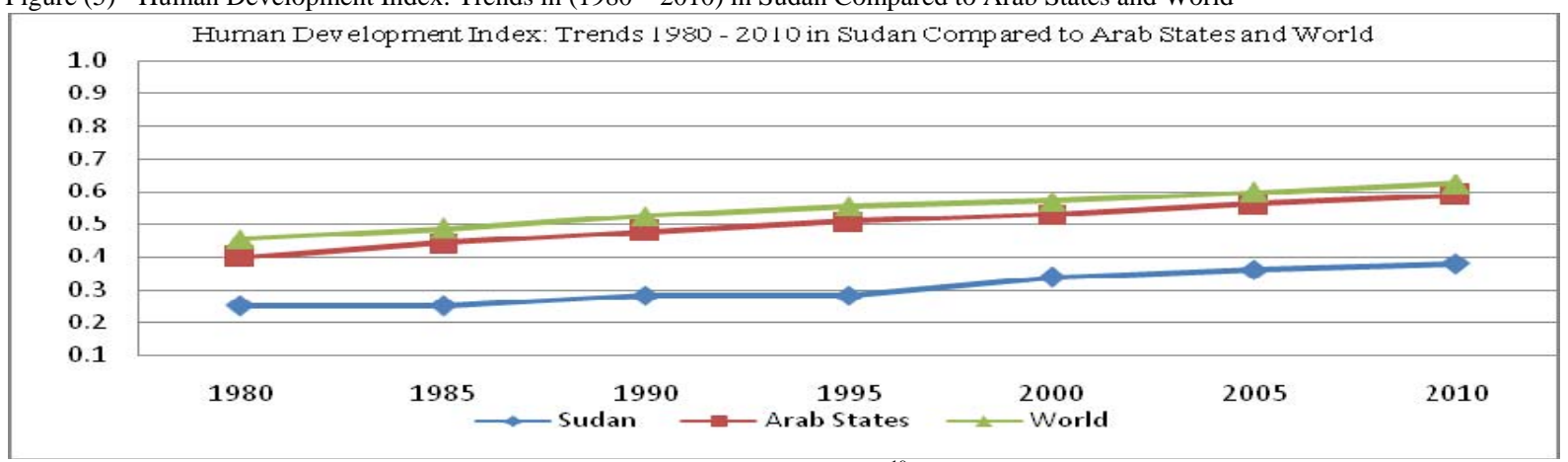

Source: UNDP Sudan Country profile of Human Development Indicators (2010) ${ }^{19}$

\footnotetext{
${ }^{19}$ See UNDP (2010): http://hdrstats.undp.org/en/countries/profiles/SDN.html, accessed on December 22, 2010.
} 


\section{Stylized facts: characteristics and structural problems of the labour in the Sudan}

Based on the above, it is now useful to explain if the structure of labour market is affected by the analysis presented in section two above. Notably, from the above analysis, we observe that the north-south conflict also contributes to increase unemployment because the civil war not only led to displacement of many workers and job loss but also implied the large spending on defense and security issues rather than prioritizing investment in social development and creation of more employment opportunities, this in turn contribute to increase in unemployment problem in Sudan. Furthermore, since the structure of Sudan economy is now related to oil, it will be useful to briefly examine the impact of oil in the labour market in Sudan. We find that oil has slight effect in the labour market because the exploration and production of oil leads to creation of more employment opportunities -although difficult to elaborate due to lack of accurate recent data. For instance, of total labour force estimated at 9,7000,000 in 2001, the share and contribution of oil industries in total employment is very minimal and accounted for only $0.0087 \%$ of total employment of labour force in Sudan (2001) and only $0.52 \%$ of total employment in the industrial manufacturing sector in Sudan (2001). It is worthy to note that the contribution of oil industries represent only $0.52 \%$ of total employment and $0.64 \%$ of total number of labour employed in the industrial manufacturing sector in Sudan (2001) but in the meantime oil industries is ranked second in terms of the contribution to industrial value added as it accounts for $11 \%$ of total industrial value added in the manufacturing industries in Sudan, this implies that oil industries tend to use more capital intensive techniques and to be a more capital intensive industry. For instance, in the three oil establishments included in the comprehensive industrial survey (2005), the total employment was 846 and the total labour was 845 (of which production workers were 830 and non production workers were 15) in 2001. ${ }^{20}$ Moreover, other impact of oil in the labour market is that the inflow of FDI and the increased wealth from oil has encouraged migration to the Sudan. Consequently, migrant workers have increased in the labour market, particularly in the private sector, which has also affected the structure of labour market and contribute to high unemployment rate. Furthermore, oil also affected the structure of wages and lead to wage differential in Sudan, for instance, the results of the comprehensive industrial survey (2005), indicates that the highest compensation for workers in the industrial sector is reported in the petroleum refining industry which is 18 times more than the average compensation in the industry in 2001. ${ }^{21}$

Based on the above, it would be interesting to begin with explaining the stylized facts on the characteristics and structural problems of labour market in the Sudan. First we explain the relation between the structure of labour market and the demographic structure, participation rates

\footnotetext{
${ }^{20}$ See for instance, Sudan central bureau of statistics Statistical Year Book (2001), Khartoum, November 2003 for the data on the total number of labor force in Sudan in 2001.See for instance, the Sudan Ministry of Industry (2005) the Comprehensive Industrial Survey data for (2001) (Tables 12- 13: the industrial survey pp.72-75) for the data on total number and share of oil in total employment and in employment in the industrial manufacturing sector in Sudan in 2001.
} 
and economic activities, second we show the relation between the structure of labour market and the low skill level and brain drain problems and finally we examine the relation between the structure of labour market and the unemployment and youth unemployment problems in Sudan.

\subsection{Labour market structure, demographic structure, participation rate and economic activities}

Before explaining the relation between the structure of labour market and the demographic structure, participation rate and economic activities, it is useful to identify the major stylized facts and characteristics of labour market in the developing countries. For instance, we observe that one stylized fact that characterized the labour market in Sudan as in many other Arab and typically developing countries is the dominance-reflected in the large share- of the public (government) sector in total employment compared to the weakness of the private sector. Majority of employed workers are concentrated in the traditional agricultural sector, while manufacturing and industrial sectors have only marginal share in total sectoral employment. The techniques of production are most likely characterized by high labour intensity and low capital intensity, low productivity of labour and small rates of return on employment (real wages). The labour market is characterized by weak, informal and unsystematic role for the labour union or workers associations, weak social security system and social protection for workers, lack of unemployment insurance, weak and inefficient regulations and institutional settings to organize the labour market, rigidity and lack of dynamism, deficiency in employment, monitoring, planning and skill upgrading. In addition to the high incidence of duality (due to presence of two sectors together: rural-urban; traditional-modern and formal-informal); prevalence of high rates of unemployment, especially among youth population and child labour. ${ }^{22}$ Increasing share of youth in total population and labour force, low participation rates, especially low participation rates for women. Mismatch between educational output (supply) and labour market requirements (demand). These distinctive features of Sudan and Arab labour markets were caused by such fundamental forces as high population and labour force growth rates, macroeconomic fluctuations caused by oil price instability, and the pervasive role of the State in the region's economic activity... A demographic transition which resulted in rapid population growth, slow down in labour absorption and combined with large-scale shifts of population from rural to urban areas, led to severe pressures on labour markets, especially in urban areas. ${ }^{23}$ In addition to increasing debate that in the Arab oil dependent countries, the structure of labour market suffers from the impacts of the Dutch disease.

One stylized fact of labour market in Sudan is related to the demographic structure for Sudan which indicates continuous and rapid increase in total population from 10 million in 1956

\footnotetext{
${ }^{21}$ See the Executive Summary of the Sudan Comprehensive Industrial Survey, (2005), p. 29.

${ }^{22}$ Based on the UNDP (2010) definition of child labour as the percentage of children ages (5-14) in the labour market the UNDPHDR (2010) indicates the high rates of child labour in Sudan as the percentage of children ages (5-14) in the labour market in Sudan that accounted for 13\% of children ages (5-14) over the period (1999-2007)- see UNDP-HDR (2010), p. 191.
} 
to 39 million in 2008; and increase in the growth rate in total population from 2.1 in 1956 to 2.8 in 2008 - see Figures 6-7 below. According to the central bureau of Statistics (2010), data from the 2008 population census indicates that the share of urban population is $29.5 \%$ compared to rural and nomad population which is $70.5 \%$ of Sudan total population, and the share of population aged (5-24) represents about $47.38 \%$ of the total population in Sudan in $2008 .{ }^{24}$ Moreover, the findings from the central bureau of Statistics (2010), data from the 2008 population census indicates that the structure and distribution of the total population by main geographic areas, gender and age indicates that the share of the north (78.9\%) is higher than the share of the south (21.1\%); the share of male (51.27\%) is higher than female (48.73\%), the share of population with 17 years old and over (52.85\%) is higher than the share of the population with 16 years old and less (47.15\%)-see Table 5 below. This structure and distribution of total population by main geographic areas, gender, age and mode of living will have several important implications in the structure of labour market, notably, labour force, participation rates, economic activities, skill level, employment and unemployment rates as we will explain in this section.

For instance, we observe that the first implication and stylized fact is that the continuous increase in the total population implies continuous increase in the total labour force from 16.5 in 1998 to 21.5 in 2006 and to 22.5 in 2008- see Table 6 below. Another stylized fact in the labour market in Sudan is the low participation rates. For instance, data from Arab Labour Organization, Sudan Ministry of Labour and Public Service Migration and Labour Force Surveys 1993 and 1996 and Sudan central bureau of statistic (2010) the Fifth Sudan Population and Housing Census (2008) show that the demographic structure and labour force (15 years and above) in Sudan, implies that the share of Sudanese women in labour force (31.1\%) is less than Sudanese men (72.2\%) and total Sudanese labour force (52.4\%). The participation rate (for 1524 years old) for Sudanese women (6.08\%) is less than that of Sudanese men (15\%), less than total Sudanese participation rate (10.08\%). Both crude and adjusted participation rates show continuous rapid increase in the period 1990-1996, in Sudan. Our findings indicates that compared to 1996 in 2008 the crude participation rates for the total population increased to (43.68\%), but they declined for men (28.99\%) and for women (14.69\%), whereas adjusted participation rates declined for men (57.90\%) and increased for women (29.42\%). Both crude and adjusted labour force participation rates in economic activities defined by mode of living and gender, indicate that the participation rates are higher for people (men and women) living in rural areas compared to people (men and women) living in urban areas and participation rates for women are less than men over the period 1990-2008. In 2008 crude and adjusted labour force participation rates in economic activities defined by main geographical areas, indicate that the

\footnotetext{
${ }^{23}$ See for instance, Shaban, Assaad and Al-Qudsi, (1995).
} 
crude participation rates are higher for people (men and women) living in the north region compared to people (men and women) living in the south, whereas the opposite is true for the adjusted participation rates- see Table 7 below. These findings are consistent with the findings from the 1993 population census and 1996 migration and labour force survey. These findings are also consistent with the structure and distribution of population in Sudan in 2008 defined by gender, mode of living and main geographical areas as we explained above.

Figures 6-7- Total Population (Million) and Population Growth Rare (\%) in Sudan over the period (1955/1956-2008)

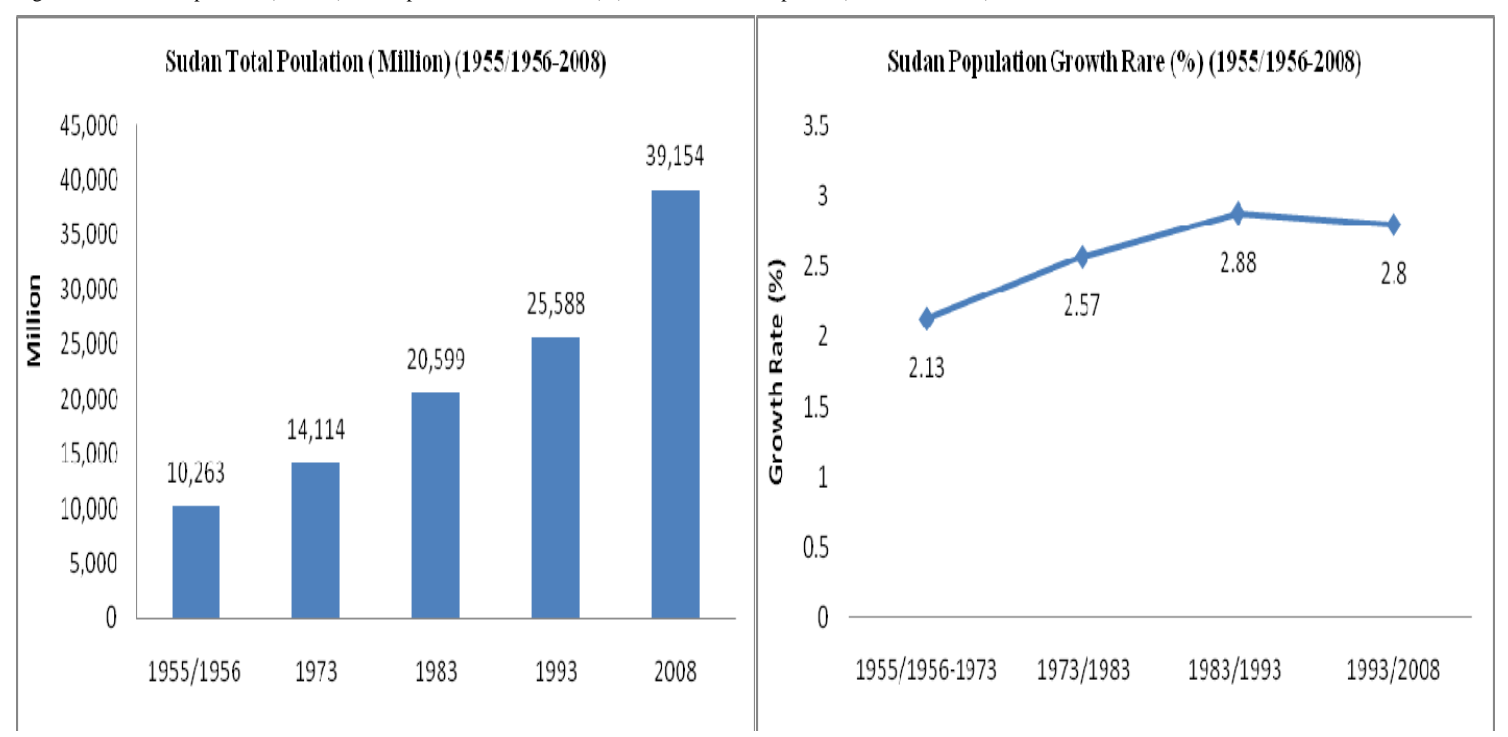

Source: Adapted from Sudan Central Bureau of Statistics Population Census Data (2010): The Fifth Sudan Population and Housing Census (2008)

Table (5) - The Distribution of Sudan Total Population defined by Main Geographical Areas, Age and Gender (2008)

\begin{tabular}{|c|c|c|c|c|c|c|c|c|c|}
\hline \multicolumn{10}{|l|}{ All Sudan } \\
\hline Age Groups & Total & Male & Female & Total & Male & Female & & & \\
\hline Total & $39,154,490$ & $20,073,977$ & $19,080,513$ & $100.00 \%$ & $51.27 \%$ & $48.73 \%$ & & & \\
\hline $00-04$ & $5,845,991$ & $3,005,746$ & $2,840,245$ & $14.93 \%$ & $7.68 \%$ & $7.25 \%$ & & & \\
\hline $05-09$ & $5,801,776$ & $3,023,603$ & $2,778,173$ & $14.82 \%$ & $7.72 \%$ & $7.10 \%$ & & & \\
\hline $10-14$ & $5,036,037$ & $2,689,626$ & $2,346,411$ & $12.86 \%$ & $6.87 \%$ & $5.99 \%$ & & & \\
\hline $00-14$ & $16,683,804$ & $8,718,975$ & $7,964,829$ & $42.61 \%$ & $22.27 \%$ & $20.34 \%$ & & & \\
\hline $15-19$ & $4,176,355$ & $2,151,401$ & $2,024,954$ & $10.67 \%$ & $5.49 \%$ & $5.17 \%$ & & & \\
\hline $20-24$ & $3,537,012$ & $1,740,076$ & $1,796,936$ & $9.03 \%$ & $4.44 \%$ & $4.59 \%$ & & & \\
\hline $15-24$ & $7,713,367$ & $3,891,477$ & $3,821,890$ & $19.70 \%$ & $9.94 \%$ & $9.76 \%$ & & & \\
\hline $25-29$ & $3,114,966$ & $1,466,418$ & $1,648,548$ & $7.96 \%$ & $3.75 \%$ & $4.21 \%$ & & & \\
\hline $30-34$ & $2,503,963$ & $1,207,987$ & $1,295,976$ & $6.40 \%$ & $3.09 \%$ & $3.31 \%$ & & & \\
\hline $35-39$ & $2,314,365$ & $1,134,069$ & $1,180,296$ & $5.91 \%$ & $2.90 \%$ & $3.01 \%$ & & & \\
\hline $25-39$ & $7,933,294$ & $3,808,474$ & $4,124,820$ & $20.26 \%$ & $9.73 \%$ & $10.53 \%$ & & & \\
\hline $40-44$ & $1,773,831$ & 905,533 & 868,298 & $4.53 \%$ & $2.31 \%$ & $2.22 \%$ & & & \\
\hline $45-49$ & $1,303,680$ & 689,233 & 614,447 & $3.33 \%$ & $1.76 \%$ & $1.57 \%$ & & & \\
\hline $50-54$ & $1,094,706$ & 581,191 & 513,515 & $2.80 \%$ & $1.48 \%$ & $1.31 \%$ & & & \\
\hline $55-59$ & 635,801 & 350,041 & 285,760 & $1.62 \%$ & $0.89 \%$ & $0.73 \%$ & & & \\
\hline $40-59$ & $4,808,018$ & $2,525,998$ & $2,282,020$ & $12.28 \%$ & $6.45 \%$ & $5.83 \%$ & & & \\
\hline $60-64$ & 691,103 & 380,847 & 310,256 & $1.77 \%$ & $0.97 \%$ & $0.79 \%$ & & & \\
\hline $65-69$ & 396,288 & 227,674 & 168,614 & $1.01 \%$ & $0.58 \%$ & $0.43 \%$ & & & \\
\hline $70-74$ & 415,695 & 229,753 & 185,942 & $1.06 \%$ & $0.59 \%$ & $0.47 \%$ & & & \\
\hline $75-79$ & 193,068 & 112,065 & 81,003 & $0.49 \%$ & $0.29 \%$ & $0.21 \%$ & & & \\
\hline $80-84$ & 178,990 & 97,556 & 81,434 & $0.46 \%$ & $0.25 \%$ & $0.21 \%$ & & & \\
\hline $85-89$ & 65,235 & 38,504 & 26,731 & $0.17 \%$ & $0.10 \%$ & $0.07 \%$ & & & \\
\hline $90-94$ & 41,546 & 23,528 & 18,018 & $0.11 \%$ & $0.06 \%$ & $0.05 \%$ & & & \\
\hline 95 and over & 34,082 & 19,126 & 14,956 & $0.09 \%$ & $0.05 \%$ & $0.04 \%$ & & & \\
\hline 60 and over & $2,016,007$ & $1,129,053$ & 886,954 & $5.15 \%$ & $2.88 \%$ & $2.27 \%$ & & & \\
\hline Main Geographical Areas & \multicolumn{3}{|c|}{ Total } & \multicolumn{3}{|c|}{$00-16$} & \multicolumn{3}{|c|}{17 and above } \\
\hline Total & Total & Male & Female & Total & Male & Female & Total & Male & Female \\
\hline All Sudan & $39,154,490$ & $20,073,977$ & $19,080,513$ & $18,462,359$ & $9,654,379$ & $8,807,980$ & $20,692,131$ & $10,419,598$ & $10,272,533$ \\
\hline Northern Sudan & $30,894,000$ & $15,786,677$ & $15,107,323$ & $14,414,910$ & $7,505,749$ & $6,909,161$ & $16,479,090$ & $8,280,928$ & $8,198,162$ \\
\hline Southern Sudan & $8,260,490$ & $4,287,300$ & $3,973,190$ & $4,047,449$ & $2,148,630$ & $1,898,819$ & $4,213,041$ & $2,138,670$ & $2,074,371$ \\
\hline \multicolumn{10}{|l|}{ Share in Total (\%) } \\
\hline All Sudan & $100.00 \%$ & $51.27 \%$ & $48.73 \%$ & $47.15 \%$ & $24.66 \%$ & $22.50 \%$ & $52.85 \%$ & $26.61 \%$ & $26.24 \%$ \\
\hline Northern Sudan & $78.90 \%$ & $40.32 \%$ & $38.58 \%$ & $36.82 \%$ & $19.17 \%$ & $17.65 \%$ & $42.09 \%$ & $21.15 \%$ & $20.94 \%$ \\
\hline Southern Sudan & $21.10 \%$ & $10.95 \%$ & $10.15 \%$ & $10.34 \%$ & $5.49 \%$ & $4.85 \%$ & $10.76 \%$ & $5.46 \%$ & $5.30 \%$ \\
\hline
\end{tabular}

${ }^{24}$ See Sudan Central Bureau of Statistics (2008) "Central Bureau of Statistics: Sudan Statistics and Statistical Year Book: Sudan (1990- 2008)” Sudan central Bureau of Statistics, Sudan Ministry of the Cabinet, 2008, p. 3. 
Table (6) Basic Indicators of labour force, unemployment and inflation rates in Sudan over the period (1990-2008)

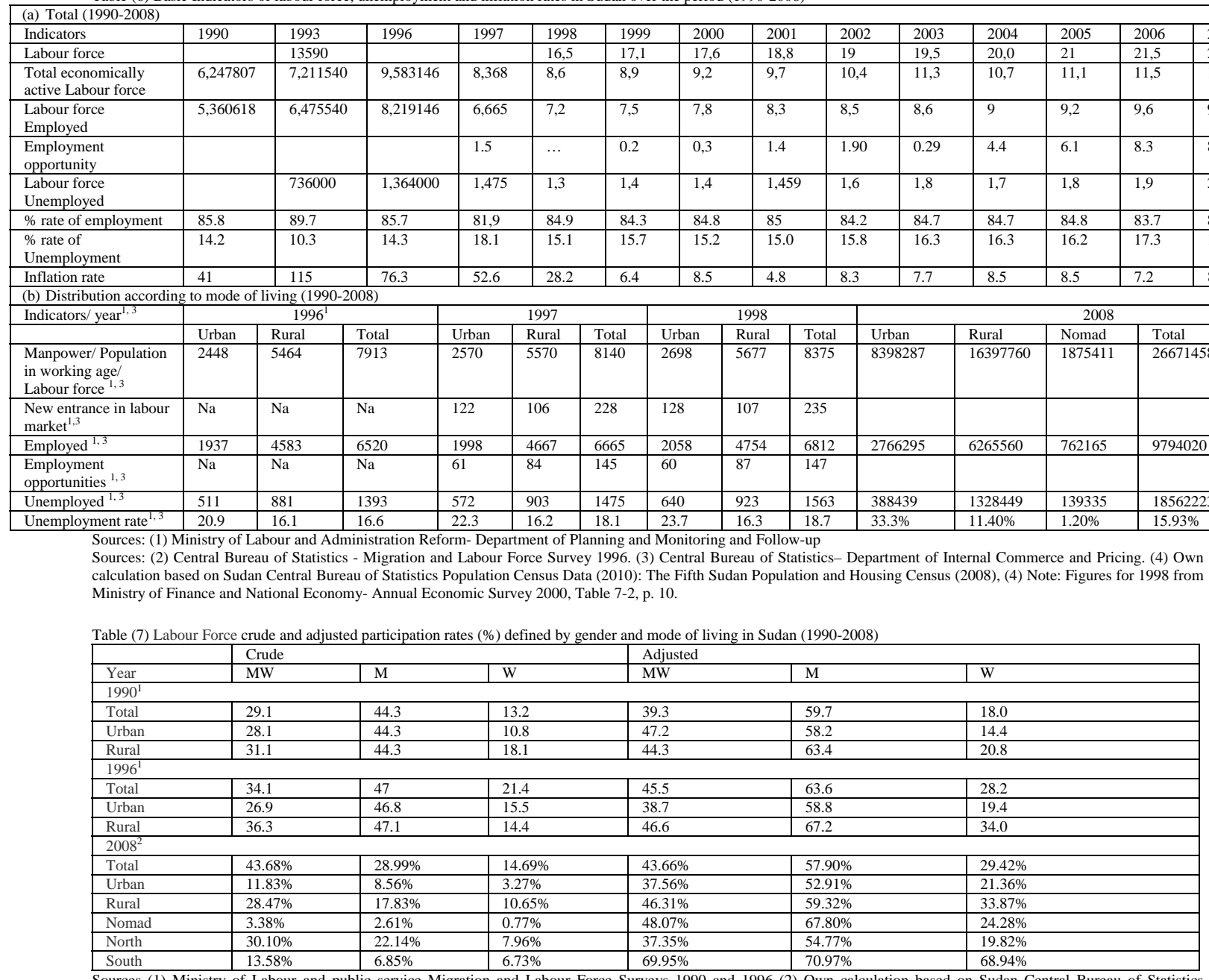

Sources (1) Ministry of Labour and public service Migration and Labour Force Surveys 1990 and 1996 (2) Own calculation based on Sudan Central Bureau of Statistics Population Census Data (2010): The Fifth Sudan Population and Housing Census (2008). Note: Participation rate for 1990 and 1996 refers to the Northern Sudan.

Another stylized fact on the structure of labour market in Sudan is the inconsistent distribution of the economically active population according to major economic activities (sectoral classification) defined by gender in Sudan. For example, according to Arab Labour Organization (2007) data for 2004 and Sudan central bureau of statistic (2010) population census data for 2008 indicate that the majority of Sudanese are employed in agriculture, fishing and forest activities (51.8\%; $48.56 \%$ ), followed by services sector (23\%, 31\%), industry (8.9\%, 7.65\%) and finally few are employed in other activities (1.2\%, 12.24\%) in 2004 and 2008 respectively. This structure implies that agriculture is still the predominant activity in Sudan, although its share of the labour force has gradually declined as other sectors of economic activity have expanded. In the 2008 census almost 48.56 percent of the work force were involved in agriculture, livestock raising, forestry, fisheries, or hunting, compared with 60.74 in 1993 and 51.08 in 2004. Services, which included a government work force that grew in terms of employment emerged as the second largest area of activity, encompassing an estimated 31.55 percent of those economically active in 2008, compared with 28.04 percent in 1993 and 23 percent in 2004. Industrial sector including manufacturing, mining, electric power, and construction- accounted for 7.65 percent in 
2008 compared to about 9.74 percent in 1993 and 8.19 percent in 2004- see Table 8 below. Sudan central bureau of statistic (2010) population census data for 2008 indicates that the majority of Sudanese men are employed in the agriculture sector (48.13\%), followed by services (35.9\%), industry (10.22\%) and other activities (5.75\%), similarly, the majority of Sudanese women are employed in the agriculture sector (49.48\%), followed by services sector (22.45\%), industry (2.27\%) and other activities (25.8\%). Employed Sudanese men constitute the majority of total employment in all sectors (67.67\%), whereas employed Sudanese women constitute the minority of total employment in all sectors (32.33\%). Sudanese men employed in agriculture, fishing and forest activities, services and industry sectors (32.57\%, 24.29\% and 6.92\% respectively) are higher than Sudanese women employed in these sectors (16\%, $7.26 \%$ and $0.73 \%$ respectively). This implies that Sudanese men employed in agriculture, fishing and forest activities, services and industry sectors are near to twice, near to three times, and near to seven times Sudanese women employed in these sectors respectively. These findings are consistent with the findings from the 1993 population census and 1996 migration and labour force survey. These findings are also consistent with the structure and distribution of population in Sudan in 2008 defined by gender as we explained above.

\begin{tabular}{|c|c|c|c|c|c|c|c|c|c|c|c|}
\hline $\begin{array}{l}\text { (a) Economically active population by economic } \\
\text { activities and gender }\end{array}$ & 1993 & & 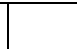 & 2004 & 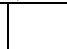 & 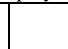 & 2008 & & & 2008 & \\
\hline & M & $\mathrm{W}$ & MW & M & $\mathrm{W}$ & MW & M & W & MW & $\mathrm{M}$ & W \\
\hline Agriculture Hunting, Forestry and Fishing & $38.79 \%$ & $21.94 \%$ & $60.74 \%$ & 32.6 & 18.46 & 51.08 & $32.57 \%$ & $16.00 \%$ & $48.56 \%$ & $48.13 \%$ & $49.48 \%$ \\
\hline Industry & $9.09 \%$ & $0.65 \%$ & $9.74 \%$ & 7.63 & 1 & 8.19 & $6.92 \%$ & $0.73 \%$ & $7.65 \%$ & $10.22 \%$ & $2.27 \%$ \\
\hline Mining and quarrying & $0.06 \%$ & $0.00 \%$ & $0.06 \%$ & 0.05 & 0 & 0.05 & $0.14 \%$ & $0.03 \%$ & $0.17 \%$ & $0.21 \%$ & $.09 \%$ \\
\hline Manufacturing & $4.81 \%$ & $0.54 \%$ & $5.35 \%$ & 4.04 & 0.46 & 4.5 & $3.09 \%$ & $0.43 \%$ & $3.52 \%$ & $4.57 \%$ & $1.32 \%$ \\
\hline Electricity, Gas and Water, & $0.69 \%$ & $0.05 \%$ & $0.73 \%$ & 0.58 & 0.04 & 0.62 & $0.33 \%$ & $0.04 \%$ & $0.37 \%$ & $0.49 \%$ & $0.12 \%$ \\
\hline Construction & $3.53 \%$ & $0.07 \%$ & $3.59 \%$ & 2.96 & 0.06 & 3.02 & $3.35 \%$ & $0.24 \%$ & $3.59 \%$ & $4.95 \%$ & $0.73 \%$ \\
\hline Services & $23.51 \%$ & $4.53 \%$ & $28.04 \%$ & 19.61 & 4 & 23 & $24.29 \%$ & $7.26 \%$ & $31.55 \%$ & $35.90 \%$ & $22.45 \%$ \\
\hline Wholesale and Retail Trade, Restaurants and Hotels & $8.03 \%$ & $0.83 \%$ & $8.86 \%$ & 6.72 & 0.7 & 7.45 & $8.13 \%$ & $1.67 \%$ & $9.79 \%$ & $12.01 \%$ & $5.15 \%$ \\
\hline Transport, Storage and Communication & $4.18 \%$ & $0.12 \%$ & $4.30 \%$ & 3.39 & 0.12 & 3.51 & $4.20 \%$ & $0.24 \%$ & $4.44 \%$ & $6.21 \%$ & $0.73 \%$ \\
\hline Financing, Insurance, Real Estate and Business Services & $0.86 \%$ & $0.18 \%$ & $1.04 \%$ & 0.72 & 0.15 & 0.87 & $0.16 \%$ & $0.05 \%$ & $0.21 \%$ & $0.24 \%$ & $0.15 \%$ \\
\hline Community, Social and Personal Services & $10.45 \%$ & $3.40 \%$ & $13.84 \%$ & 8.78 & 2.64 & 11.42 & $11.81 \%$ & $5.32 \%$ & $17.11 \%$ & $17.43 \%$ & $16.41 \%$ \\
\hline Activities Not Adequately Defined or Classified & $1.07 \%$ & $0.41 \%$ & $1.49 \%$ & 0.64 & 0.56 & 1.2 & $3.89 \%$ & $8.34 \%$ & $12.24 \%$ & $5.75 \%$ & $25.80 \%$ \\
\hline Total & $72.46 \%$ & $27.54 \%$ & 100 & & & & $67.67 \%$ & $32.33 \%$ & $100.00 \%$ & $100.00 \%$ & $100.00 \%$ \\
\hline Seeking work & & & & 11.25 & 4.6 & & & & & & \\
\hline Unemployed & & & & na & na & 16.3 & & & & & \\
\hline Total & & & & 100 & 100 & 100 & & & & & \\
\hline \multicolumn{12}{|l|}{ (b) Economically active population by employment status } \\
\hline Category & Total & $\%$ & $\%$ & & & & & & & & \\
\hline Employer & 581,500 & 5 & 6 & & & & & & & & \\
\hline Own account (private) worker & $4,272,000$ & 40 & 41 & & & & & & & & \\
\hline Employee (paid worker) & $3,813,000$ & 35 & 36 & & & & & & & & \\
\hline Unpaid family worker & $1,787,400$ & 17 & 17 & & & & & & & & \\
\hline Other and unemployed worker & 246,100 & 2 & & & & & & & & & \\
\hline TOTAL & $10,700,000$ & 100 & 100 & & & & & & & & \\
\hline
\end{tabular}

\subsection{Labour market structure, the low skill level and brain drain problems}

Another stylized fact on the structure of labour market in Sudan can be observed from the skill level defined by occupation (defined by the international definition of major occupational groups classification) and education (defined by school attendance, literacy and education attainment) defined by gender and main geographic areas. For example, using the definition of skill according to occupation classification, the Arab Labour Organization (2007) data for 2004 and Sudan central bureau of statistic (2010) population census data for 2008 indicate that the majority of Sudanese economically active population or workers are medium and low skilled 
(86\%; 83\%) and minority (14\%; 12\%) are high skilled. In 2004 only 14\% of men are high skilled and $86 \%$ are medium and low skilled, only $15 \%$ of women are high skilled and $85 \%$ are medium and low skilled, women are slightly more skilled than men. In 2008 only 13\% of men are high skilled and $79 \%$ are medium and low skilled, only $10 \%$ of women are high skilled and $84 \%$ are medium and low skilled, men are slightly more skilled than women. The majority of Sudanese workers are employed in blue collar occupation (70\%, 69.4\%), while the minority are employed in white collar occupation (30\%, 24.4\%) in 2004 and 2008 respectively. In 2004 only 33\% of men are employed in white collar occupation, while $67 \%$ of men are employed in blue collar occupation, only $24 \%$ of women are employed in white collar occupation, while $76 \%$ of women are employed in blue collar occupation. In 2008 only 23.24\% of men are employed in white collar occupation, while $73.42 \%$ of men are employed in blue collar occupation, only $26.9 \%$ of women are employed in white collar occupation, while $61.03 \%$ of women are employed in blue collar occupation. The classification of skill according to main geographical areas indicates that the skill level in the north is higher than in the south region- see Table 9 below. Moreover, our results from Sudan central bureau of statistic (2010) population census data for 2008 indicate the low skill level and differences in skill level in Sudan that appear in term of low school attendance, literacy rate and education attainment defined by gender, mode of living and main geographical areas. For instance the distribution of total Sudan population 6 years of age and over according to school attendance and literacy implies that only little above half of Sudan population 6 years of age and over are currently and/or previously school attending school (50.87\%) and are literate (51.59\%), while near to half of Sudan population 6 years of age and over have never attended school (44.62\%) and are illiterate (45.19\%). Moreover, the distribution of total Sudan population 6 years of age and over according to education attainment implies that about $8.30 \%$ of total Sudan population 6 years of age and over are without educational attainment. The distribution of population 6 years and above according to education attainment and currently and/or previously school attendance implies that the majority are with below primary education (42.58\%), this is followed by primary education (14.84\%), secondary education (12.83\%), intermediate education (4.84\%), university first degree education (4.70\%), post secondary diploma education (1.10\%), post graduate diploma education (0.29\%), Masters degree education (0.24\%) and Ph.D. degree education (0.09\%). Furthermore, the distribution of population 6 years of age and over according to previous and/or current school attendance implies that the majority are with primary education and intermediate education and less than secondary education (19.70\%), this is followed by secondary education (12.83\%), and finally followed by only minority with above secondary education (5.32\%) (including post secondary diploma, university first degree, post graduate diploma, Masters degree and Ph.D. degree). In addition, the distribution of population 6 years of age and over according to current school attendance implies that the majority are with primary education and less than secondary 
education (73.59\%), followed by secondary education (15.09\%), and finally followed by only minority with above secondary education (6.72\%) (including $0.31 \%$ are with post secondary diploma, $0.56 \%$ are with college education, $5.36 \%$ are with university first degree education, $0.29 \%$ are with post graduate diploma education, $0.16 \%$ are with Masters degree education and 0.04\% are with Ph.D. degree education). Moreover, our results from Sudan central bureau of statistic (2010) population census data for 2008 indicate the low skill level and differences in skill level in Sudan that appear in term of low school attendance, literacy rate and education attainment defined by gender, mode of living and main geographical areas. For instance, the skill level defined by school attendance, literacy rate and education attainment for male are higher than women, for urban are higher than rural and for north are higher than and south- see Tables 10-12 below. These findings are consistent with the structure and distribution of population in Sudan in 2008 defined by gender, mode of living and main geographical areas as we explained above.

\begin{tabular}{|c|c|c|c|c|c|c|c|c|c|c|}
\hline Major Occupational Groups ${ }^{25}$ & 2004 & & & 2008 & & & 2008 & & & \\
\hline & $\mathrm{M}$ & W & MW & $\mathrm{M}$ & $\mathrm{W}$ & MW & $\mathrm{M}$ & $\mathrm{W}$ & North & South \\
\hline Professional, scientists, technical, associate professionals and related workers & 8.80 & 14.72 & 10.46 & $3.58 \%$ & $2.39 \%$ & $9.78 \%$ & $10.92 \%$ & $7.41 \%$ & $4.76 \%$ & $1.23 \%$ \\
\hline Administrative and managerial workers & 5.25 & 0.10 & 3.81 & $5.03 \%$ & $0.55 \%$ & $5.57 \%$ & $7.43 \%$ & $1.69 \%$ & $5.35 \%$ & $0.23 \%$ \\
\hline White Collar high skilled (WCHS) & 14.05 & 14.82 & 14.27 & $8.61 \%$ & $2.94 \%$ & $11.55 \%$ & $12.73 \%$ & $9.08 \%$ & $10.10 \%$ & $1.45 \%$ \\
\hline Clerks and related workers & 4.00 & 5.90 & 4.53 & $1.43 \%$ & $0.72 \%$ & $2.15 \%$ & $2.12 \%$ & $2.22 \%$ & $1.94 \%$ & $0.21 \%$ \\
\hline Sales workers and shop and market service workers & 15.00 & 3.15 & 11.67 & $5.68 \%$ & $5.05 \%$ & $10.73 \%$ & $3.40 \%$ & $15.61 \%$ & $4.15 \%$ & $6.58 \%$ \\
\hline White Collar low skilled (WCLS) & 19 & 9.05 & 16.2 & $7.11 \%$ & $5.76 \%$ & $12.88 \%$ & $10.51 \%$ & $17.83 \%$ & $6.09 \%$ & $6.78 \%$ \\
\hline Agriculture animal husbandry and forestry workers & 46.90 & 69.59 & 53.26 & $21.66 \%$ & $14.52 \%$ & 36.18\% & $32.01 \%$ & $44.90 \%$ & $17.07 \%$ & $19.11 \%$ \\
\hline Blue Collar high skilled (BCHS) & 46.90 & 69.59 & 53.26 & $28.58 \%$ & $15.28 \%$ & $43.86 \%$ & $42.24 \%$ & $47.25 \%$ & $24.13 \%$ & $19.73 \%$ \\
\hline Production and related workers, transport equipment operators and labour & 20.04 & 6.53 & 16.25 & & & & & & & \\
\hline Blue Collar low skilled (BCLS) & 20.04 & 6.53 & 16.25 & $21.10 \%$ & $4.46 \%$ & $25.56 \%$ & $31.18 \%$ & $13.78 \%$ & $2.03 \%$ & $3.52 \%$ \\
\hline Services workers, workers not classifiable by occupation and unemployed workers & ha & na & na & 0 & 0 & p & p & p & p & p \\
\hline Craft and related trades workers & & & & $6.92 \%$ & $0.76 \%$ & $7.68 \%$ & $10.22 \%$ & $2.36 \%$ & $7.06 \%$ & $0.62 \%$ \\
\hline Plant and machine operators, and assemblers & & & & $3.03 \%$ & $0.14 \%$ & $3.17 \%$ & $4.48 \%$ & $0.42 \%$ & $3.01 \%$ & $0.16 \%$ \\
\hline Elementary occupations & & & & $18.07 \%$ & $4.32 \%$ & $22.39 \%$ & $26.70 \%$ & $13.36 \%$ & $19.03 \%$ & $3.36 \%$ \\
\hline Not Stated & & & & $2.26 \%$ & $3.90 \%$ & $5.16 \%$ & $3.35 \%$ & $12.06 \%$ & $6.16 \%$ & $0.00 \%$ \\
\hline Total & 100.00 & 100 & 100. & & & & & & & \\
\hline White Collar (WC= WCHS + WCLS) & 33.05 & 23.87 & 30.47 & $15.72 \%$ & $8.70 \%$ & $24.42 \%$ & $23.24 \%$ & $26.90 \%$ & $16.19 \%$ & $8.23 \%$ \\
\hline Blue Collar (BC=BCHS +BCLS) & 66.94 & 76 & 70 & $49.68 \%$ & $19.73 \%$ & $69.41 \%$ & $73.42 \%$ & $61.03 \%$ & $46.16 \%$ & $23.25 \%$ \\
\hline High skilled (HS= WCHS) & 14 & 15 & 14 & $8.61 \%$ & $2.94 \%$ & $11.55 \%$ & $12.73 \%$ & $9.08 \%$ & $10.10 \%$ & $1.45 \%$ \\
\hline Medium and Low skilled (MLS=WCLS + BCHS+ BCLS) & 86 & 85 & 86 & $56.79 \%$ & $25.50 \%$ & B2.30\% & $78.86 \%$ & B3.93\% & $52.25 \%$ & $30.03 \%$ \\
\hline
\end{tabular}

Sources: Adapted from the Arab Labour Organization (2007), (2) Central Bureau of Statistics- Department of Internal Commerce and Pricing. (3) Own calculation based on Sudan Central Bureau of Statistics Population Census Data (2010): The Fifth Sudan Population and Housing Census (2008).

\footnotetext{
${ }^{25}$ The ILO International Standards Classification of Occupations (ISCO) are aggregated in the following way (high skilled includes only the category of WCHS, while medium and low skilled include all other categories: WCLS, BCHS and BCLS):

White-Collar high-skilled (WCHS) includes legislators, senior officials, managers, professionals, technicians and associate professionals.

White-Collar low-skilled (WCLS) includes clerks, services workers, shop and market sales workers.

Blue-Collar high-skilled (BCHS) includes skilled agricultural and fishery workers, craft and related trade workers.

Blue-Collar low-skilled (BCLS) includes plant and machine operators and assemblers and elementary occupations.
} 
Table 10 - Sudan-population 6 years of age and over by school attendance and literacy defined by age, sex, regions and mode of living

\begin{tabular}{|c|c|c|c|c|c|c|c|c|c|c|c|}
\hline & & $\begin{array}{l}\text { Currently } \\
\text { Attended }\end{array}$ & $\begin{array}{l}\text { Previously } \\
\text { Attended }\end{array}$ & $\begin{array}{l}\text { Currently + } \\
\text { Previously Attended }\end{array}$ & $\begin{array}{l}\text { Never } \\
\text { Attended }\end{array}$ & $\begin{array}{l}\text { Not } \\
\text { Stated }\end{array}$ & Total & Literate & Illiterate & $\begin{array}{l}\text { Not } \\
\text { Stated }\end{array}$ & Total \\
\hline \multirow{7}{*}{ All Sudan } & Age Group & & & & & & & & & & \\
\hline & Total 6 and over & $25.50 \%$ & $25.38 \%$ & $50.87 \%$ & $44.62 \%$ & $4.51 \%$ & $100.00 \%$ & $51.59 \%$ & $45.19 \%$ & $3.22 \%$ & $100 \%$ \\
\hline & $10-14$ & $15.67 \%$ & $1.09 \%$ & $16.76 \%$ & $11.77 \%$ & $1.75 \%$ & $30.27 \%$ & $16.61 \%$ & $12.14 \%$ & $1.52 \%$ & $30.27 \%$ \\
\hline & $15-24$ & $8.38 \%$ & $6.10 \%$ & $14.47 \%$ & $8.69 \%$ & $0.80 \%$ & $23.96 \%$ & $14.61 \%$ & $8.75 \%$ & $0.60 \%$ & $23.96 \%$ \\
\hline & $25-39$ & $1.19 \%$ & $11.08 \%$ & $12.27 \%$ & $11.30 \%$ & $0.89 \%$ & $24.46 \%$ & $12.57 \%$ & $11.35 \%$ & $0.53 \%$ & $24.46 \%$ \\
\hline & $40-59$ & $0.20 \%$ & $5.67 \%$ & $5.88 \%$ & $8.40 \%$ & $0.69 \%$ & $14.97 \%$ & $6.16 \%$ & $8.46 \%$ & $0.35 \%$ & $14.97 \%$ \\
\hline & 60 and over & $0.06 \%$ & $1.43 \%$ & $1.49 \%$ & $4.46 \%$ & $0.39 \%$ & $6.34 \%$ & $1.64 \%$ & $4.49 \%$ & $0.21 \%$ & $6.34 \%$ \\
\hline \multicolumn{12}{|c|}{ Total 6 \& over } \\
\hline \multicolumn{12}{|c|}{ All Sudan (Total 6 \& over) } \\
\hline & Total (MF) & $25.50 \%$ & $25.38 \%$ & $50.87 \%$ & $44.62 \%$ & $4.51 \%$ & $100 \%$ & $51.59 \%$ & $45.19 \%$ & $3.22 \%$ & $100 \%$ \\
\hline & Male (M) & $14.07 \%$ & $14.49 \%$ & $28.57 \%$ & $19.78 \%$ & $2.01 \%$ & $50.35 \%$ & $29.05 \%$ & $19.78 \%$ & $1.52 \%$ & $50.35 \%$ \\
\hline & Female (F) & $11.42 \%$ & $10.88 \%$ & $22.30 \%$ & $24.84 \%$ & $2.50 \%$ & $49.65 \%$ & $22.54 \%$ & $25.41 \%$ & $1.70 \%$ & $49.65 \%$ \\
\hline & Urban & $10.44 \%$ & $11.89 \%$ & $22.33 \%$ & $7.02 \%$ & $1.22 \%$ & $30.57 \%$ & $22.56 \%$ & $7.21 \%$ & $0.80 \%$ & $30.57 \%$ \\
\hline & Rural & $14.47 \%$ & $13.03 \%$ & $27.50 \%$ & $31.88 \%$ & $2.83 \%$ & $62.20 \%$ & $27.90 \%$ & $32.31 \%$ & $1.99 \%$ & $62.20 \%$ \\
\hline & Nomad & $0.59 \%$ & $0.46 \%$ & $1.04 \%$ & $5.72 \%$ & $0.47 \%$ & $7.23 \%$ & $1.13 \%$ & $5.68 \%$ & $0.43 \%$ & $7.23 \%$ \\
\hline \multicolumn{12}{|c|}{ North (Total 6 \& over) } \\
\hline & Total (MF) & $21.82 \%$ & $23.29 \%$ & $45.11 \%$ & $30.54 \%$ & $4.51 \%$ & $80.16 \%$ & $45.83 \%$ & $31.11 \%$ & $3.22 \%$ & $80.16 \%$ \\
\hline & Male (M) & $11.86 \%$ & $13.21 \%$ & $25.06 \%$ & $13.31 \%$ & $2.01 \%$ & $40.39 \%$ & $25.55 \%$ & $13.32 \%$ & $1.52 \%$ & $40.39 \%$ \\
\hline & Female (F) & $9.96 \%$ & $10.08 \%$ & $20.05 \%$ & $17.22 \%$ & $2.50 \%$ & $39.77 \%$ & $20.28 \%$ & $17.79 \%$ & $1.70 \%$ & $39.77 \%$ \\
\hline & Urban & $9.35 \%$ & $11.21 \%$ & $20.56 \%$ & $5.31 \%$ & $1.22 \%$ & $27.09 \%$ & $20.80 \%$ & $5.49 \%$ & $0.80 \%$ & $27.09 \%$ \\
\hline & Rural & $11.88 \%$ & $11.62 \%$ & $23.50 \%$ & $19.51 \%$ & $2.83 \%$ & $45.84 \%$ & $23.90 \%$ & $19.95 \%$ & $1.99 \%$ & $45.84 \%$ \\
\hline & Nomad & $0.59 \%$ & $0.46 \%$ & $1.04 \%$ & $5.72 \%$ & $0.47 \%$ & $7.23 \%$ & $1.13 \%$ & $5.68 \%$ & $0.43 \%$ & $7.23 \%$ \\
\hline \multicolumn{12}{|c|}{ South (Total 6 \& over) } \\
\hline & Total (MF) & $3.67 \%$ & $2.08 \%$ & $5.76 \%$ & $14.08 \%$ & $0.00 \%$ & $19.84 \%$ & $5.76 \%$ & $14.08 \%$ & $0.00 \%$ & $19.84 \%$ \\
\hline & Male (M) & $2.21 \%$ & $1.29 \%$ & $3.50 \%$ & $6.46 \%$ & $0.00 \%$ & $9.97 \%$ & $3.50 \%$ & $6.46 \%$ & $0.00 \%$ & $9.97 \%$ \\
\hline & Female $(\mathrm{F})$ & $1.46 \%$ & $0.80 \%$ & $2.26 \%$ & $7.61 \%$ & $0.00 \%$ & $9.87 \%$ & $2.26 \%$ & $7.61 \%$ & $0.00 \%$ & $9.87 \%$ \\
\hline & Urban & $1.08 \%$ & $0.68 \%$ & $1.77 \%$ & $1.71 \%$ & $0.00 \%$ & $3.48 \%$ & $1.77 \%$ & $1.71 \%$ & $0.00 \%$ & $3.48 \%$ \\
\hline & Rural & $2.59 \%$ & $1.40 \%$ & $3.99 \%$ & $12.36 \%$ & $0.00 \%$ & $16.36 \%$ & $3.99 \%$ & $12.36 \%$ & $0.00 \%$ & $16.36 \%$ \\
\hline & Nomad & $0.00 \%$ & $0.00 \%$ & $0.00 \%$ & $0.00 \%$ & $0.00 \%$ & $0.00 \%$ & $0.00 \%$ & $0.00 \%$ & $0.00 \%$ & $0.00 \%$ \\
\hline
\end{tabular}

Table 11- Sudan population 6 years of age and over currently and previously attending school by education attainment, age, sex, regions and mode of living

\begin{tabular}{|c|c|c|c|c|c|c|c|c|c|c|c|c|c|c|c|}
\hline & 을 & 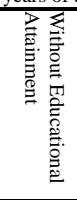 & 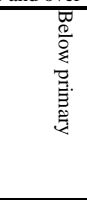 & 害. & 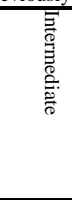 & 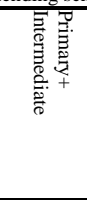 & 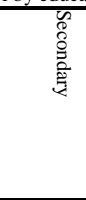 & 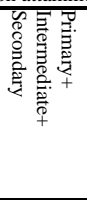 & 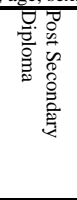 & 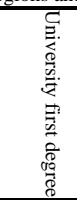 & 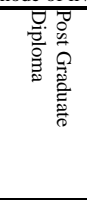 & 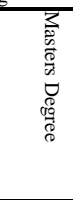 & ت्ञ & 离 & 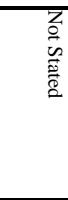 \\
\hline \multicolumn{16}{|c|}{ All Sudan (age group) } \\
\hline Total & $100.00 \%$ & $8.30 \%$ & $42.58 \%$ & $14.84 \%$ & $4.86 \%$ & $19.70 \%$ & $12.83 \%$ & $32.53 \%$ & $1.10 \%$ & $4.70 \%$ & $0.29 \%$ & $0.24 \%$ & $0.09 \%$ & $6.22 \%$ & $3.97 \%$ \\
\hline $6--14$ & $32.95 \%$ & $1.24 \%$ & $28.77 \%$ & $0.78 \%$ & $0.08 \%$ & $0.87 \%$ & $0.09 \%$ & $0.96 \%$ & $0.00 \%$ & $0.01 \%$ & $0.00 \%$ & $0.00 \%$ & $0.00 \%$ & $1.05 \%$ & $0.92 \%$ \\
\hline $25-39$ & $24.12 \%$ & $3.00 \%$ & $3.33 \%$ & $3.87 \%$ & $2.34 \%$ & $6.21 \%$ & $5.28 \%$ & $11.49 \%$ & $0.50 \%$ & $2.76 \%$ & $0.15 \%$ & $0.11 \%$ & $0.02 \%$ & $1.61 \%$ & $1.14 \%$ \\
\hline $40-59$ & $11.55 \%$ & $1.28 \%$ & $0.81 \%$ & $2.38 \%$ & $1.45 \%$ & $3.83 \%$ & $2.23 \%$ & $6.07 \%$ & $0.33 \%$ & $0.85 \%$ & $0.08 \%$ & $0.10 \%$ & $0.04 \%$ & $1.51 \%$ & $0.49 \%$ \\
\hline $60+$ & $2.93 \%$ & $0.30 \%$ & $0.15 \%$ & $0.76 \%$ & $0.21 \%$ & $0.97 \%$ & $0.23 \%$ & $1.19 \%$ & $0.07 \%$ & $0.11 \%$ & $0.02 \%$ & $0.02 \%$ & $0.02 \%$ & $0.91 \%$ & $0.15 \%$ \\
\hline \multicolumn{16}{|c|}{ All Sudan (Total 6 and over) } \\
\hline Total & $100.00 \%$ & $8.30 \%$ & $42.58 \%$ & $14.84 \%$ & $4.86 \%$ & $19.70 \%$ & $12.83 \%$ & $32.53 \%$ & $1.10 \%$ & $4.70 \%$ & $0.29 \%$ & $0.24 \%$ & $0.09 \%$ & $6.22 \%$ & $3.97 \%$ \\
\hline male & $56.16 \%$ & $4.48 \%$ & $23.39 \%$ & $8.31 \%$ & $2.89 \%$ & $11.20 \%$ & $7.11 \%$ & $18.30 \%$ & $0.69 \%$ & $2.52 \%$ & $0.17 \%$ & $0.16 \%$ & $0.06 \%$ & $4.22 \%$ & $2.15 \%$ \\
\hline female & $43.85 \%$ & $3.82 \%$ & $19.18 \%$ & $6.53 \%$ & $1.97 \%$ & $8.50 \%$ & $5.73 \%$ & $14.23 \%$ & $0.40 \%$ & $2.18 \%$ & $0.11 \%$ & $0.08 \%$ & $0.02 \%$ & $2.00 \%$ & $1.82 \%$ \\
\hline rural & $43.89 \%$ & $2.69 \%$ & $15.51 \%$ & $7.21 \%$ & $2.58 \%$ & $9.79 \%$ & $7.84 \%$ & $17.63 \%$ & $0.68 \%$ & $3.51 \%$ & $0.21 \%$ & $0.20 \%$ & $0.06 \%$ & $1.57 \%$ & $1.83 \%$ \\
\hline urban & $54.06 \%$ & $5.46 \%$ & $26.04 \%$ & $7.48 \%$ & $2.22 \%$ & $9.70 \%$ & $4.91 \%$ & $14.61 \%$ & $0.41 \%$ & $1.17 \%$ & $0.07 \%$ & $0.04 \%$ & $0.02 \%$ & $4.22 \%$ & $2.02 \%$ \\
\hline \multicolumn{16}{|c|}{ North (Total 6 and over) } \\
\hline Total & $88.68 \%$ & $6.50 \%$ & $36.48 \%$ & $13.27 \%$ & $4.62 \%$ & $17.89 \%$ & $11.70 \%$ & $29.59 \%$ & $0.81 \%$ & $4.58 \%$ & $0.25 \%$ & $0.22 \%$ & $0.08 \%$ & $6.19 \%$ & $3.97 \%$ \\
\hline male & $49.27 \%$ & $3.54 \%$ & $19.81 \%$ & $7.27 \%$ & $2.72 \%$ & $9.99 \%$ & $6.33 \%$ & $16.32 \%$ & $0.49 \%$ & $2.43 \%$ & $0.15 \%$ & $0.14 \%$ & $0.06 \%$ & $4.20 \%$ & $2.15 \%$ \\
\hline female & $39.41 \%$ & $2.96 \%$ & $16.68 \%$ & $6.00 \%$ & $1.90 \%$ & $7.91 \%$ & $5.37 \%$ & $13.28 \%$ & $0.32 \%$ & $2.16 \%$ & $0.10 \%$ & $0.08 \%$ & $0.02 \%$ & $1.99 \%$ & $1.82 \%$ \\
\hline rural & $40.42 \%$ & $2.25 \%$ & $13.80 \%$ & $6.69 \%$ & $2.50 \%$ & $9.18 \%$ & $7.38 \%$ & $16.57 \%$ & $0.55 \%$ & $3.44 \%$ & $0.19 \%$ & $0.19 \%$ & $0.06 \%$ & $1.56 \%$ & $1.83 \%$ \\
\hline urban & $46.21 \%$ & $4.11 \%$ & $21.65 \%$ & $6.43 \%$ & $2.07 \%$ & $8.50 \%$ & $4.23 \%$ & $12.73 \%$ & $0.26 \%$ & $1.13 \%$ & $0.06 \%$ & $0.03 \%$ & $0.02 \%$ & $4.20 \%$ & $2.02 \%$ \\
\hline nomad & $2.05 \%$ & $0.15 \%$ & $1.03 \%$ & $0.15 \%$ & $0.06 \%$ & $0.21 \%$ & $0.09 \%$ & $0.29 \%$ & $0.01 \%$ & $0.02 \%$ & $0.00 \%$ & $0.00 \%$ & $0.00 \%$ & $0.42 \%$ & $0.12 \%$ \\
\hline \multicolumn{16}{|c|}{ South (Total 6 and over) } \\
\hline Total & $11.32 \%$ & $1.79 \%$ & $6.10 \%$ & $1.57 \%$ & $0.23 \%$ & $1.81 \%$ & $1.13 \%$ & $2.94 \%$ & $0.28 \%$ & $0.11 \%$ & $0.04 \%$ & $0.02 \%$ & $0.01 \%$ & $0.03 \%$ & $0.00 \%$ \\
\hline male & $6.88 \%$ & $0.94 \%$ & $3.59 \%$ & $1.04 \%$ & $0.17 \%$ & $1.21 \%$ & $0.78 \%$ & $1.99 \%$ & $0.20 \%$ & $0.09 \%$ & $0.03 \%$ & $0.02 \%$ & $0.01 \%$ & $0.03 \%$ & $0.00 \%$ \\
\hline female & $4.44 \%$ & $0.86 \%$ & $2.51 \%$ & $0.53 \%$ & $0.07 \%$ & $0.60 \%$ & $0.35 \%$ & $0.95 \%$ & $0.08 \%$ & $0.03 \%$ & $0.01 \%$ & $0.01 \%$ & $0.00 \%$ & $0.01 \%$ & $0.00 \%$ \\
\hline rural & $3.47 \%$ & $0.44 \%$ & $1.71 \%$ & $0.53 \%$ & $0.08 \%$ & $0.61 \%$ & $0.46 \%$ & $1.07 \%$ & $0.13 \%$ & $0.07 \%$ & $0.02 \%$ & $0.02 \%$ & $0.00 \%$ & $0.01 \%$ & $0.00 \%$ \\
\hline urban & $7.85 \%$ & $1.35 \%$ & $4.39 \%$ & $1.05 \%$ & $0.15 \%$ & $1.20 \%$ & $0.67 \%$ & $1.87 \%$ & $0.15 \%$ & $0.04 \%$ & $0.02 \%$ & $0.01 \%$ & $0.00 \%$ & $0.02 \%$ & $0.00 \%$ \\
\hline
\end{tabular}


Table 12 - Sudan population 6 years of age and over currently attending school by grade attending, age in single years and sex

\begin{tabular}{|c|c|c|c|c|c|c|c|c|c|c|c|c|c|}
\hline & & total & & & urban & & & rural & & & nomad & & \\
\hline & & MF & $\mathrm{M}$ & F & MF & $\mathrm{M}$ & F & MF & $\mathrm{M}$ & $\mathrm{F}$ & MF & $\mathrm{M}$ & F \\
\hline \multicolumn{14}{|l|}{ Total } \\
\hline & All Sudan & $100.00 \%$ & $55.20 \%$ & $44.80 \%$ & $40.94 \%$ & $21.59 \%$ & $19.35 \%$ & $56.76 \%$ & $32.14 \%$ & $24.63 \%$ & $2.30 \%$ & $1.47 \%$ & $0.83 \%$ \\
\hline & North & $85.59 \%$ & $46.52 \%$ & $39.07 \%$ & $36.68 \%$ & $19.11 \%$ & $17.57 \%$ & $46.60 \%$ & $25.93 \%$ & $20.67 \%$ & $2.30 \%$ & $1.47 \%$ & $0.83 \%$ \\
\hline & South & $14.41 \%$ & $8.68 \%$ & $5.73 \%$ & $4.25 \%$ & $2.47 \%$ & $1.78 \%$ & $10.16 \%$ & $6.21 \%$ & $3.95 \%$ & $0.00 \%$ & $0.00 \%$ & $0.00 \%$ \\
\hline \multicolumn{14}{|c|}{ Primary } \\
\hline & All Sudan & $73.59 \%$ & $40.65 \%$ & $32.94 \%$ & $26.82 \%$ & $14.12 \%$ & $12.70 \%$ & $44.94 \%$ & $25.37 \%$ & $19.56 \%$ & $1.84 \%$ & $1.16 \%$ & $0.68 \%$ \\
\hline & North & $61.43 \%$ & $33.49 \%$ & $27.93 \%$ & $23.41 \%$ & $12.21 \%$ & $11.20 \%$ & $36.18 \%$ & $20.12 \%$ & $16.06 \%$ & $1.84 \%$ & $1.16 \%$ & $0.68 \%$ \\
\hline & South & $12.16 \%$ & $7.16 \%$ & $5.00 \%$ & $3.41 \%$ & $1.91 \%$ & $1.50 \%$ & $8.76 \%$ & $5.25 \%$ & $3.51 \%$ & $0.00 \%$ & $0.00 \%$ & $0.00 \%$ \\
\hline \multicolumn{14}{|c|}{ Secondary } \\
\hline & All Sudan & $15.09 \%$ & $8.42 \%$ & $6.66 \%$ & $7.74 \%$ & $4.14 \%$ & $3.60 \%$ & $7.12 \%$ & $4.13 \%$ & $2.98 \%$ & $0.23 \%$ & $0.15 \%$ & $0.08 \%$ \\
\hline & North & $13.22 \%$ & $7.16 \%$ & $6.05 \%$ & $7.07 \%$ & $3.69 \%$ & $3.37 \%$ & $5.92 \%$ & $3.32 \%$ & $2.60 \%$ & $0.23 \%$ & $0.15 \%$ & $0.08 \%$ \\
\hline & South & $1.87 \%$ & $1.26 \%$ & $0.61 \%$ & $0.67 \%$ & $0.44 \%$ & $0.23 \%$ & $1.20 \%$ & $0.82 \%$ & $0.38 \%$ & $0.00 \%$ & $0.00 \%$ & $0.00 \%$ \\
\hline \multicolumn{14}{|c|}{ Post Secondary/Diploma Program } \\
\hline & All Sudan & $0.31 \%$ & $0.20 \%$ & $0.12 \%$ & $0.17 \%$ & $0.10 \%$ & $0.07 \%$ & $0.14 \%$ & $0.09 \%$ & $0.05 \%$ & $0.01 \%$ & $0.01 \%$ & $0.00 \%$ \\
\hline & North & $0.23 \%$ & $0.14 \%$ & $0.09 \%$ & $0.14 \%$ & $0.08 \%$ & $0.06 \%$ & $0.08 \%$ & $0.05 \%$ & $0.03 \%$ & $0.01 \%$ & $0.01 \%$ & $0.00 \%$ \\
\hline & South & $0.09 \%$ & $0.06 \%$ & $0.03 \%$ & $0.03 \%$ & $0.02 \%$ & $0.01 \%$ & $0.06 \%$ & $0.04 \%$ & $0.02 \%$ & $0.00 \%$ & $0.00 \%$ & $0.00 \%$ \\
\hline \multicolumn{14}{|c|}{$\begin{array}{l}1 \\
\text { College } \\
\end{array}$} \\
\hline & All Sudan & $0.56 \%$ & $0.31 \%$ & $0.25 \%$ & $0.34 \%$ & $0.18 \%$ & $0.16 \%$ & $0.22 \%$ & $0.12 \%$ & $0.09 \%$ & $0.01 \%$ & $0.00 \%$ & $0.00 \%$ \\
\hline & North & $0.48 \%$ & $0.25 \%$ & $0.23 \%$ & $0.32 \%$ & $0.17 \%$ & $0.15 \%$ & $0.16 \%$ & $0.08 \%$ & $0.07 \%$ & $0.01 \%$ & $0.00 \%$ & $0.00 \%$ \\
\hline & South & $0.08 \%$ & $0.05 \%$ & $0.03 \%$ & $0.02 \%$ & $0.02 \%$ & $0.01 \%$ & $0.06 \%$ & $0.04 \%$ & $0.02 \%$ & $0.00 \%$ & $0.00 \%$ & $0.00 \%$ \\
\hline \multicolumn{14}{|c|}{ University } \\
\hline & All Sudan & $5.36 \%$ & $2.75 \%$ & $2.61 \%$ & $3.73 \%$ & $1.90 \%$ & $1.83 \%$ & $1.60 \%$ & $0.83 \%$ & $0.77 \%$ & $0.03 \%$ & $0.02 \%$ & $0.01 \%$ \\
\hline & North & $5.16 \%$ & $2.61 \%$ & $2.55 \%$ & $3.62 \%$ & $1.82 \%$ & $1.80 \%$ & $1.51 \%$ & $0.77 \%$ & $0.74 \%$ & $0.03 \%$ & $0.02 \%$ & $0.01 \%$ \\
\hline & South & $0.20 \%$ & $0.14 \%$ & $0.06 \%$ & $0.11 \%$ & $0.08 \%$ & $0.03 \%$ & $0.09 \%$ & $0.06 \%$ & $0.03 \%$ & $0.00 \%$ & $0.00 \%$ & $0.00 \%$ \\
\hline \multicolumn{14}{|c|}{ Master Degree } \\
\hline & All Sudan & $0.160 \%$ & $0.090 \%$ & $0.070 \%$ & $0.120 \%$ & $0.070 \%$ & $0.050 \%$ & $0.030 \%$ & $0.020 \%$ & $0.010 \%$ & $0.000 \%$ & $0.000 \%$ & $0.000 \%$ \\
\hline & North & $0.150 \%$ & $0.090 \%$ & $0.060 \%$ & $0.120 \%$ & $0.070 \%$ & $0.050 \%$ & $0.030 \%$ & $0.020 \%$ & $0.010 \%$ & $0.000 \%$ & $0.000 \%$ & $0.000 \%$ \\
\hline & South & $0.009 \%$ & $0.007 \%$ & $0.002 \%$ & $0.004 \%$ & $0.003 \%$ & $0.001 \%$ & $0.005 \%$ & $0.003 \%$ & $0.001 \%$ & $0.000 \%$ & $0.000 \%$ & $0.000 \%$ \\
\hline \multicolumn{14}{|c|}{ Ph.D Program } \\
\hline & All Sudan & $0.040 \%$ & $0.020 \%$ & $0.020 \%$ & $0.030 \%$ & $0.020 \%$ & $0.010 \%$ & $0.010 \%$ & $0.010 \%$ & $0.000 \%$ & $0.000 \%$ & $0.000 \%$ & $0.000 \%$ \\
\hline & North & $0.040 \%$ & $0.020 \%$ & $0.010 \%$ & $0.020 \%$ & $0.010 \%$ & $0.010 \%$ & $0.010 \%$ & $0.010 \%$ & $0.000 \%$ & $0.000 \%$ & $0.000 \%$ & $0.000 \%$ \\
\hline & South & $0.004 \%$ & $0.002 \%$ & $0.002 \%$ & $0.003 \%$ & $0.002 \%$ & $0.001 \%$ & $0.001 \%$ & $0.000 \%$ & $0.000 \%$ & $0.000 \%$ & $0.000 \%$ & $0.000 \%$ \\
\hline \multicolumn{14}{|c|}{ Not Reported } \\
\hline & All Sudan & $4.89 \%$ & $2.75 \%$ & $2.14 \%$ & $1.99 \%$ & $1.06 \%$ & $0.93 \%$ & $2.71 \%$ & $1.56 \%$ & $1.15 \%$ & $0.19 \%$ & $0.12 \%$ & $0.06 \%$ \\
\hline & North & $4.89 \%$ & $2.75 \%$ & $2.14 \%$ & $1.99 \%$ & $1.06 \%$ & $0.93 \%$ & $2.71 \%$ & $1.56 \%$ & $1.15 \%$ & $0.19 \%$ & $0.12 \%$ & $0.06 \%$ \\
\hline & South & $0.00 \%$ & $0.00 \%$ & $0.00 \%$ & $0.00 \%$ & $0.00 \%$ & $0.00 \%$ & $0.00 \%$ & $0.00 \%$ & $0.00 \%$ & $0.00 \%$ & $0.00 \%$ & $0.00 \%$ \\
\hline
\end{tabular}

One stylized fact on the labour market in Sudan is that since long Sudan remains a labour exporting country, especially to the Arab rich oil Gulf countries, for instance, since long many male Sudanese has worked in other Arab Gulf states, notably, the migration of high skill led to brain drain problem in Sudan. ${ }^{26}$ Based on the conventional views in the literature on the incidence of the brain drain in the typically developing countries, in our view the main reasons for the incidence and continuation of brain in Sudan can be perceived from both country and

\footnotetext{
26 "The term human capital flight, more commonly referred to as "brain drain", is the large-scale emigration of individuals with technical skills or knowledge. The reasons usually include two aspects which respectively come from countries and individuals. In terms of countries, the reasons may be social environment (in source countries: lack of opportunities, political instability, economic depression, health risks; in host countries: rich opportunities, comparatively good political system, developed economy, better living conditions). In terms of individual reasons, there are family influences (overseas relatives, and personal preference: preference for exploring, ambition for an improved career, etc.). Although the term originally referred to technology workers leaving a nation, the meaning has broadened into: "the departure of educated or professional people from one country, economic sector, or field for another, usually for better pay or living conditions". Brain drain is usually regarded as an economic cost, since emigrants usually take with them the fraction of value of their training sponsored by the government or other organizations. It is a parallel of capital flight, which refers to the same movement of financial capital. Brain drain is often associated with de-skilling of emigrants in their country of destination, while their country of emigration experiences the draining of skilled individuals. The term brain drain was coined by the Royal Society to describe the emigration of "scientists and technologists" to North America from post war Europe. Another source indicates that this term was first used in the United Kingdom to describe the influx of Indian scientist and engineers. The converse phenomenon is "brain gain", which occurs when there is a large-scale immigration of technically qualified persons. Brain drain is common amongst developing nations, such as Africa, former colonies of the island nations of the Caribbean, and particularly in centralized economies such as former East Germany and the Soviet Union, where marketable skills were not financially rewarded. Two parties involved in brain drain are developing countries and developed countries. On the left side, because of the disadvantaged social environment (of opportunities, political instability, economic depression, health risks, etc), family influence (overseas relatives, etc), and personal preference (prefer exploring, ambitious to seek brilliant career, etc), many people in developing countries actively choose to migrate. Most of migrations from developing countries are those wealthy or skilled people, whose leaving results in brain drain and slow development of home countries. This contributes to a vicious circle for developing countries (low-income countries). On the other side, the advantaged social environment (rich opportunities, comparatively good political system, developed economy, better living conditions, etc) in developed countries attract talents from other areas, which contribute to brain drain, and finally forms a virtuous circle" See http://en.wikipedia.org/wiki/Brain_drain, accessed in November 14, 2010.
} 
personal perspectives. From the country perspective, the main reasons are related to internal environment in Sudan due to lack of employment opportunities, political instability and economic instability; in host countries: rich employment opportunities and better living conditions. From the personal perspective the main reasons include family influences (overseas relatives, and personal preference: preference for an improved career, and better living conditions etc.). The most important reason for the continuation of brain in Sudan is particularly because the low standard of economic development led to low GDP Per capita, which implies that the high skills are not financially rewarded. The main consequences of the brain drain problem in Sudan is that the brain drain regarded as an economic cost, since emigrants usually take with them the fraction of value of their training sponsored by the government or other organizations. Moreover, the brain drain implies that Sudan experiences the draining of skilled individuals and this contributes to vicious circle of underdevelopment in Sudan as a low-income country. This problem of a brain drain implies a loss to Sudan that may have amounted to a considerable percent of its professional and skilled work force. For instance over the period (2005-2008) the average share of white collar high and white collar Sudanese migrants workers represent about $8.57 \%$ and $11.39 \%$ of total Sudanese migrant workers respectively. Notably, the share of white collar high continuously increased from $5.87 \%$ to $9.42 \%, 7.71 \%$ and $9.83 \%$ in 2005, 2006, 2007 and 2008 respectively, and the share of white collar increased from 12.66\% to 13.03\%, 18\% and then declined to 6.6\% in 2005, 2006, 2007 and 2008 respectively- see Table 13 below.

Table 13- The Brain Drain: Sudanese working abroad with legal contracts, classified by occupation over the period (2005-2008)

\begin{tabular}{|c|c|c|c|c|c|c|c|c|c|c|}
\hline & \multicolumn{5}{|c|}{ Total } & \multicolumn{5}{|c|}{ Share in total (\%) } \\
\hline & 2005 & 2006 & 2007 & 2008 & 2005-2008 & 2005 & 2006 & 2007 & 2008 & 2005-2008 \\
\hline Managers and Administrators & 10 & 23 & 73 & 95 & 201 & $0.12 \%$ & $0.28 \%$ & $0.53 \%$ & $0.43 \%$ & $0.38 \%$ \\
\hline Professionals and Scientists & 293 & 520 & 691 & 1617 & 3121 & $3.47 \%$ & $6.26 \%$ & $4.99 \%$ & $7.30 \%$ & $5.92 \%$ \\
\hline Technicians & 193 & 239 & 304 & 465 & 1201 & $2.28 \%$ & $2.88 \%$ & $2.19 \%$ & $2.10 \%$ & $2.28 \%$ \\
\hline Clerks and Accountants & 111 & 133 & 199 & 399 & 842 & $1.31 \%$ & $1.60 \%$ & $1.44 \%$ & $1.80 \%$ & $1.60 \%$ \\
\hline Sales and Services Workers & 462 & 167 & 1227 & 499 & 2355 & $5.47 \%$ & $2.01 \%$ & $8.86 \%$ & $2.25 \%$ & $4.46 \%$ \\
\hline Agriculture, Animal Husbandry and Hunting & 5550 & 4629 & 6160 & 13518 & 29857 & $65.70 \%$ & $55.76 \%$ & $44.46 \%$ & $61.05 \%$ & $56.60 \%$ \\
\hline Handicrafts Workers & 328 & 181 & 678 & 1635 & 2822 & $3.88 \%$ & $2.18 \%$ & $4.89 \%$ & $7.38 \%$ & $5.35 \%$ \\
\hline Plant and Machine Operators and Assemblers & 758 & 458 & 3497 & 3039 & 7752 & $8.97 \%$ & $5.52 \%$ & $25.24 \%$ & $13.72 \%$ & $14.70 \%$ \\
\hline Transportation Works & -- & 1047 & -- & -- & 1047 & $0.00 \%$ & $12.61 \%$ & $0.00 \%$ & $0.00 \%$ & $1.98 \%$ \\
\hline Elementary Occupations & 742 & 905 & 1025 & 877 & 3549 & $8.78 \%$ & $10.90 \%$ & $7.40 \%$ & $3.96 \%$ & $6.73 \%$ \\
\hline Total & 8447 & 8302 & 13854 & 22144 & 52747 & $100 \%$ & $100 \%$ & $100 \%$ & $100 \%$ & $100.00 \%$ \\
\hline White Collar High & 496 & 782 & 1068 & 2177 & 4523 & $5.87 \%$ & $9.42 \%$ & $7.71 \%$ & $9.83 \%$ & $8.57 \%$ \\
\hline White Collar Low & 573 & 300 & 1426 & 2481 & 4780 & $6.78 \%$ & $3.61 \%$ & $10.29 \%$ & $11.20 \%$ & $9.06 \%$ \\
\hline White Collar & 1069 & 1082 & 2494 & 1363 & 6008 & $12.66 \%$ & $13.03 \%$ & $18.00 \%$ & $6.16 \%$ & $11.39 \%$ \\
\hline Blue Collar High & 5878 & 4810 & 6838 & 14416 & 31942 & $69.59 \%$ & $57.94 \%$ & $49.36 \%$ & $65.10 \%$ & $60.56 \%$ \\
\hline Blue Collar Low & 1500 & 2410 & 4522 & 15652 & 24084 & $17.76 \%$ & $29.03 \%$ & $32.64 \%$ & $70.68 \%$ & $45.66 \%$ \\
\hline Blue Collar & 7378 & 7220 & 11360 & 18192 & 44150 & $87.34 \%$ & $86.97 \%$ & $82.00 \%$ & $82.15 \%$ & $83.70 \%$ \\
\hline
\end{tabular}

In addition, as a result of the brain drain problem which implies a shortage of professional and skilled Sudanese workers we find the recent phenomena of brain gain of foreign skilled workers which is most probably related to the effects of globalization and increasing foreign investment that is largely depending on foreign skills and foreign capital, the easy inflow and employment of foreign workers caused serious implication because of competition to substitute the local and domestic workers. The presence and high share of skilled foreign workers in total employment of foreign workers, means that majority of foreign workers were employed in high skilled jobs and 
competed with the Sudanese on the available job opportunities in Sudan. Notably, the share of white collar high foreign workers increased from $61 \%$ to $80 \%$, $89 \%$ and $88 \%$ in 2002, 2003 , 2005 and 2006 respectively, and the share of white collar foreign workers increased from $77 \%$ to 90\%, 96\% and 91\% in 2002, 2003, 2005 and 2006 respectively- see Table 14 below.

Table (14) Distribution of foreign workers by occupational classification (\%) in Sudan (2002-2006)

\begin{tabular}{|c|c|c|c|c|c|}
\hline (a)Distribution of foreign workers by occupational classification & 2002 & 2003 & 2004 & 2005 & 2006 \\
\hline Professionals and science & $51 \%$ & $72 \%$ & $72 \%$ & $44 \%$ & $31 \%$ \\
\hline Legislators, senior officials and managers & $7 \%$ & $6 \%$ & $12 \%$ & $9 \%$ & $11 \%$ \\
\hline Technicians and associate professionals & $3 \%$ & $2 \%$ & na & $36 \%$ & $46 \%$ \\
\hline Clerks & $2 \%$ & $1 \%$ & $3 \%$ & $1 \%$ & $1 \%$ \\
\hline Service workers and shop and market sales workers & $14 \%$ & $9 \%$ & $9 \%$ & $6 \%$ & $2 \%$ \\
\hline Skilled agricultural and fishery workers & na & $6 \%$ & na & $4 \%$ & na \\
\hline Craft and related trade workers & $0 \%$ & $1 \%$ & & na & $1 \%$ \\
\hline Plant and machine operators and assemblers & $9.5 \%$ & $3 \%$ & $4 \%$ & na & $2 \%$ \\
\hline Elementary occupations & $13.5 \%$ & na & na & na & $6 \%$ \\
\hline Total & $100 \%$ & $100 \%$ & $100 \%$ & $100 \%$ & $100 \%$ \\
\hline White Collar High & $61 \%$ & $80 \%$ & $84 \%$ & $89 \%$ & $88 \%$ \\
\hline White Collar Low & $16 \%$ & $11 \%$ & $12 \%$ & $7 \%$ & $3 \%$ \\
\hline White Collar & $77 \%$ & $90 \%$ & $96 \%$ & $96 \%$ & $91 \%$ \\
\hline Blue Collar High & $0 \%$ & $7 \%$ & $0 \%$ & $4 \%$ & $1 \%$ \\
\hline Blue Collar Low & $23 \%$ & $3 \%$ & $4 \%$ & $0 \%$ & $8 \%$ \\
\hline Blue Collar & $23 \%$ & $10 \%$ & $4 \%$ & $4 \%$ & $9 \%$ \\
\hline
\end{tabular}

Source: Adapted from the Statistics of Ministry of labour.

\subsection{Labour market structure, unemployment and youth unemployment problems}

One stylized fact in the labour market in Sudan is the serious incidence of chronically unemployment crisis - see Table 6 above. Sudan like many other Arab countries not only faces many challenges such as low per capita GDP, low growth of labour productivity, the incidence of high poverty rate, but also of persistence of high and rising unemployment rate. This persistent unemployment problem may reflect both a general problem of growth and development and a structural problem of labour market and inequality and may lead to several serious implications on hindering the process of development and economic growth. The discussion of unemployment in Sudan is important because of higher and persistent rates of unemployment- now in excess of 20 percent. Several studies in the Sudanese literature (See: cf. Ministry of Labour Report 2004-2005) indicate the problem due to the demand side, but it is also essential to reflect the interaction between the supply- demand sides and examine the problem from both perspectives. The UNDP report (2006 pp. 92-94) shows the broad employment trends in Sudan during the 1990s and illustrates a process of jobless growth over that period and highlight the need for employment creation or generation and poverty alleviation in Sudan. Different from the several studies in the Sudanese literature we explain below four stylized facts on the unemployment problem in Sudan including the presence of several types of unemployment; the interpretation of unemployment crisis in Sudan from two different endogenous and exogenous perspectives due to endogenous and exogenous causes; the high incidence of unemployment among youth population and the big mismatch between educational qualifications -supply- and labour market requirement- demand. Moreover, one advantage of our 
analysis is that we explain these stylized facts using a new data on unemployment based on Sudan central bureau of statistic (2010) population census (2008).

The first stylized fact on the incidence of unemployment in Sudan is the prevalence of the several different kinds or types of unemployment including the structural, voluntary, involuntary, seasonal, frictional, cyclical, technological, youth, disguised hidden, temporary and open chronically unemployment in Sudan. The presence of seasonal unemployment in Sudan can be perceived from the fact the majority of Sudanese labour force are still hired in the agricultural sector which is characterized by relative availability of seasonal work in agriculture. In addition the high intensity of labour and family workers in the agriculture sector probably also has caused the disguised and hidden unemployment in Sudan. Furthermore, the presence of hidden and disguised unemployment can be perceived from the fact that the public sector is still the main source of job creation in the Sudan, it has a limited capacity to hire more workers but the commitment of the government to hire beyond the capacity of the public sector has caused low productivity of workers -at least compared to other Arab countries- see Table 17 below. Furthermore, the presence of frictional unemployment can be perceived from the geographical (temporary) movement of people (displaced workers and internal refuges). Moreover, the presence of cyclical unemployment can be perceived from the economic crises over the past decades in Sudan. In addition, the presence of technological unemployment can be perceived from the recent expansion in the use of technology, especially ICT in the services, notably banking sector in Sudan. We observe that the use of new technologies in the banking sector caused displacement and substitution of workers, and contributed to reduction in the number of employment opportunities. For instance, according to the results of the survey presented in the Central Bank of Sudan (2004) aimed at assessing the impacts of the use of new technologies in the Sudanese banking system in 2004, 56.5\% of the respondents indicate that the use of new technologies in the banking system has some impacts on employment and resulted in the reduction of the number of workers and hence lead to an increase in unemployment in the Sudan. ${ }^{27}$ Furthermore, the presence of youth unemployment can be perceived from the recent information which indicates the rapid increase in unemployment rate in Sudan especially the youth unemployment rate that reached around $18 \%$ of total youth in Sudan, youth unemployment also increased amongst university graduates. In addition, the presence of involuntary unemployment can be perceived from the presence of high unemployment among youth and university graduates can be interpreted partly as compulsory unemployment and partly also structural unemployment. Moreover, the presence of voluntary unemployment can be perceived from the low participation rate, especially for women (housewife). Furthermore, the presence of structural unemployment either temporary or open chronically is persistent for a long time and it can be perceived from the consequences of the structural reform and the mismatch between 
educational qualifications for youth and requirement s in labour market. Moreover, the presence of open chronically - persistent - long-term unemployment, is perceived from the fact that the problem of unemployment existed throughout much of the period (1973-2008). During the last two decades the recorded employment creation was increased -cf. Table 6, employment opportunities increased from 0.2 in 1999 to 8.3 in 2006-; however, because of the labour force population -cf. Table 6 above, with the average participation rate remaining lowunemployment remained high and continued to rise -cf. Table 6 above. For example, in Sudan total labour force population continuously and rapidly increased from 16.5 in 1998 to 21.5 in 2006. The new entrance increased from 8.6 in 1998 to 11.5 in 2006 (rise in new entrance in urban area is rapid than in rural area, labour force increased rapidly in urban area from 2.4 to 2.5 to 2.6 in 1996, 1997 and 1998 respectively, labour force increased in rural area from 5.4, 5.5, 5.6 in 1996, 1997 and 1998 respectively, total labour force increased from 7.9, 8.1, 8.3 in 1996, 1997 and 1998 respectively. Despite the rise in total employed persons from 7.3 in 1998 to 9.6 in 2006 and employment opportunities from 0.2 in 1999 to 8.3 in 2006, but unemployed population was also increased from 1.3 million in 1998 to 2 million in 2006 and unemployment rates increased from $15.1 \%$ in 1998 to $17.3 \%$ in 2006 and $20.7 \%$ in 2008. Despite the rapid decline in inflation rates from 99.3 in 1996 to 40.9 in 1997, to 19.1 in 1998, to 18.2 in 1999, to 9 in 2004-2005 and to 7 in 2006- see Table 16 above, but unemployment rates rapidly increased. In the Sudan, the estimated average unemployment rate rose in 2008 to 20.7\% percent from 14\% during 19901996 and from 5.5\% to $11.1 \%$ during 1973-1993. Since 1973 the rate of unemployment rapidly increased and even it is more than doubled over the past fifteen years over the period (19932008), for instance, the rate of unemployment increased from $10.3 \%$ in 1993 to $20.7 \%$ in 2008 , which implies that the unemployment problem remains chronically persistent problem in Sudan.

The second stylized fact is the interpretation of unemployment crisis in Sudan from two different endogenous and exogenous perspectives due to exogenous and endogenous causes. The exogenous causes include the implications of the internal refuges and migration due to environmental problem, draught and desertification, civil war and conflict, the influx of refugees from other neighboring countries, imbalanced development strategies, globalization and the use of foreign workers. The exogenous causes also includes other factors, for instance, the drop in world oil prices in the 1980s, the Gulf War in the early 1990s and the recent increasing move towards nationalization of jobs in the Arab Gulf countries, together caused the Arab Gulf states to cut back drastically on their expatriate workers, which resulted in the departure of the thousands of Sudanese workers based in these countries, leaving many of their possessions behind, and leading in turn to increased unemployment in Sudan. Unemployment is also caused by the exogenous environmental problems, for instance unemployment figures were affected by the severe drought that spread throughout Sudan in the 1980s. In 1983-84, for example, several

\footnotetext{
${ }^{27}$ See the Central Bank of Sudan (2004), p. 36.
} 
million people migrated from the worst hit areas in both the west and the east to Khartoum and other urban areas along the Nile. Many remained in these areas once the drought had eased, living in shanty towns and contributing to unemployment or underemployment in the cities. In addition, more than 1 million people from the south migrated to the north, as a result of the civil war and famine in these areas. Moreover, the endogenous causes include the deficient demand caused by the deficient macroeconomic policies: privatization; deficient public sector, deficient private sector, structural reform, mismatch between educational output and labour market need, unemployment caused by labour market policies, educational policies, and the use of new technologies). In particular, the considerable reduction in the aggregate demand and demand for labour is caused by the liberalization, structural adjustment programs and privatization of SOEs during the 1990s that contributed to increased unemployment of the labour force (see Dagdeviren and Mahran (2004). Moreover, the deficiency and low employment of the private sectors also contributed to unemployment in Sudan (see Ministry of Labour Report 2004-2005). In addition, we find that the inflation rate is one of the very important endogenous factors that affected the unemployment problem thought it does not received adequate analysis in the Sudanese literature. For this reason, our analysis in this paper fills this gap in the Sudanese literature and discusses the correlation between inflation rates and unemployment rates. For instance, our findings imply that the increase in unemployment rates seem to be correlated with the increase in inflation rates in Sudan in the period 2000-2008. For instance, When using data and figures on unemployment rates and inflation rates over the period (1990-2008) -presented in Table 6 above- and using the ordinary least squares method to examine the correlation between inflation and unemployment rates in Sudan we find positive and significant correlation between unemployment rate and inflation rate for the case of Sudan for the period 2000-2008. We find negative significant correlation between inflation rate and unemployment rate over the period (1990-2008), and negative insignificant correlation between inflation rate and unemployment rate over the period (1990-2000). Our findings on the negative correlation between inflation rate and unemployment for the periods (1990-2008) and (1990-2000) are consistent with the studies in the literature in support of the Phillips curve. ${ }^{28}$ But our result on the positive correlation between inflation rate and unemployment for the period (2000-2008) is opposite to the findings for the periods (1990-2008) and (1990-2000) and is different from the findings in support of Phillips curve. These contrasting findings for the periods (1990-2000) and (2000-2008) implies that the correlation between inflation rates and unemployment turned from a negative into a positive correlation in Sudan- see Table 15 below and Figures 8-13 below. The major policy implication from our findings on a significant positive correlation between inflation and unemployment rates for the case of Sudan for the period (2000-2008), implies that an increase in inflation rates have caused an increase in unemployment rates over the period (2000-2008), and

\footnotetext{
${ }^{28}$ Phillips curve firstly used by Phillips (1958), it indicates a negative correlation between inflation rates and unemployment rates.
} 
so macroeconomic policies aimed at or targeting reducing inflation rates would also contribute to reduce unemployment rates- see Table 15 below.

Table (15) Correlation between unemployment and inflation rates in the Sudan (1990-2008)

\begin{tabular}{|l|l|l|l|l|l|l|}
\hline Year & \multicolumn{3}{|c|}{ SPS } & \multicolumn{3}{c|}{} \\
\hline & $\begin{array}{l}\text { Coefficient } \\
\text { (t-value) }\end{array}$ & $\mathrm{N}$ & $\mathrm{R}^{2}$ & $\begin{array}{l}\text { Coefficient } \\
\text { (t-value })\end{array}$ & $\mathrm{R}^{2}$ \\
\hline $1990-2008$ & $\begin{array}{l}-0.024^{* *} \\
(-2.192)\end{array}$ & 16 & 0.256 & $\begin{array}{l}-0.024^{* *} \\
(-2.192)\end{array}$ & 16 & 0.256 \\
\hline $1990-2000$ & -0.015 & 8 & 0.173 & $\begin{array}{l}-0.015 \\
(-1.1197)\end{array}$ & 8 & 0.173 \\
\hline $2000-2008$ & $\begin{array}{l}(-1.119) \\
(2.857 * *\end{array}$ & 9 & 0.538 & $\begin{array}{l}0.567^{* *} \\
(2.857)\end{array}$ & 9 & 0.538 \\
\hline
\end{tabular}

**Correlation is significant at the 0.5 level of significance.

Figures 8- 13 - The relation between Unemployment and Inflation and Rates in Sudan (\%) (1990-2008)
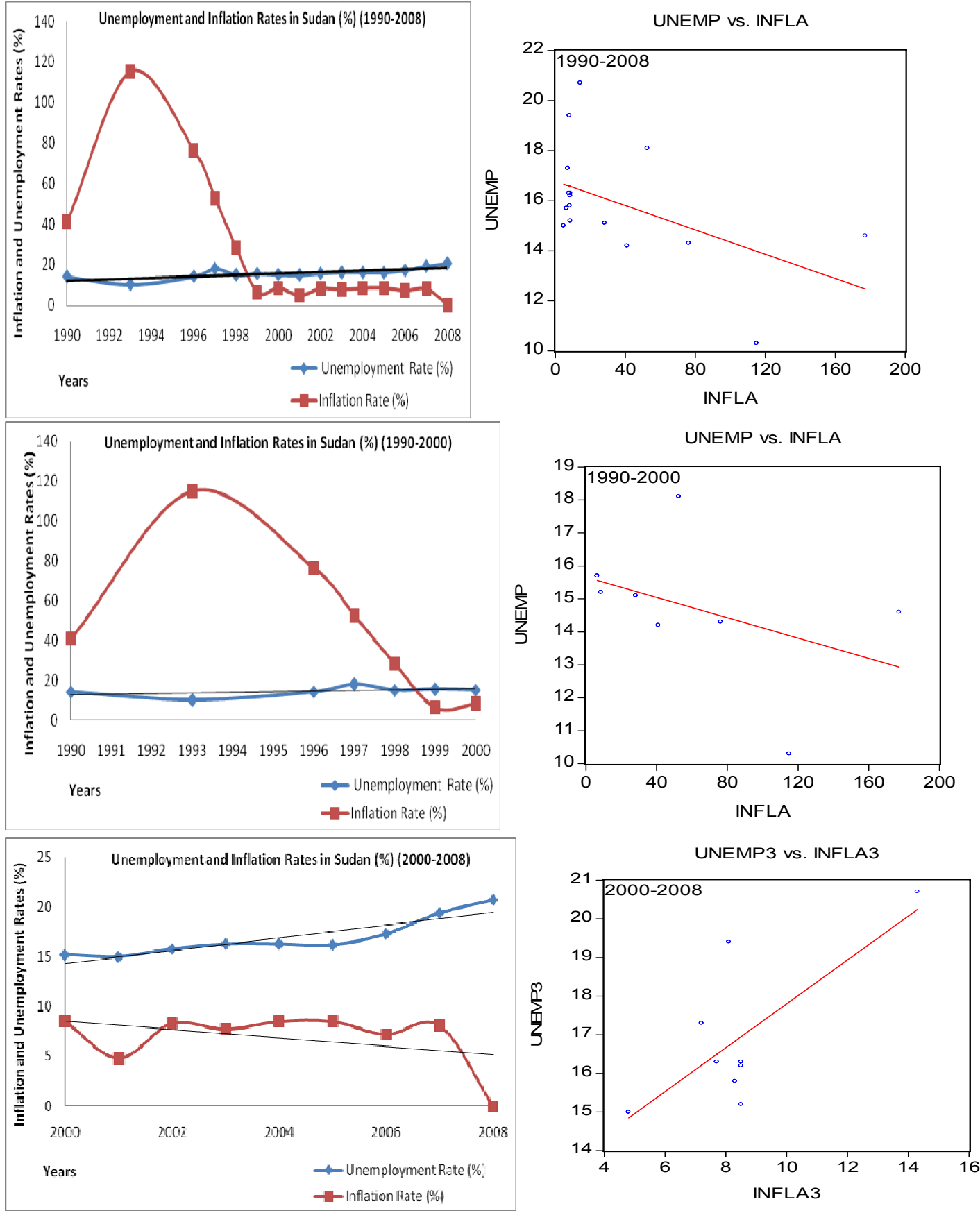

Source: Own calculation based on data obtained from (1) the Central Bank of Sudan, (2) the central bureau of statistics (3) Ministry of Finance and National Economy- and (4) Ministry of Labour and public service Annual Economic Reports (various issues) 
The third stylized fact on the incidence of unemployment in Sudan is the high unemployment among youth population- see Figures 14-15 below. Sudan like many other typically developing countries not only suffered from high annual population growth rate (2.8\%) and a very high rate of unemployment (20.7\%) but also the population structure in the Sudan as in many other Arab countries -with a high percentage of the young- makes the situation of unemployment even more worse and difficult as most of the population is under 25 years of age,” this category of young people represents 22.9 per cent of the total population in 2006 the Sudan, such a population structure has prompted the need to create more job opportunities and is anticipated to put more pressure in the future demands for jobs in the Sudan. This situation lead to a very high rate of unemployment among youth population, for example, according to Arab Labour Organization (2007) data for 2004 indicates that the high rates of youth unemployment among Sudanese youth (41.25\%), female (43.25\%) and male (36.64\%). The estimated unemployment among Sudanese youth (41.25\%) is among the highest in the world: $2.9 \%$ as much as the international world rate, 2.6\% as much as in Latin America and the Pacific rate, 2.5\% as much as in South East Asia rate and $1.4 \%$ as much as the Arab rate)- see Table 17 below. This worse situation has placed Sudan as the fifth worst ranked after Algeria, Iraq, Mauritania and Somalia amongst the Arab countries". ${ }^{29}$ This situation would not only resulted in unemployment but also caused a state of mismatch and underemployment in Sudan as some people were forced to take up jobs for low compensation packages that do not suit their qualifications." (cf. Ministry of Labour Report 2004-2005). ${ }^{30}$

The above findings on the high rate of unemployment for youth population is also consistent with the findings based on the data from Sudan Census data for 1993 and Ministry of Labour and Public Service Migration and Labour Force Surveys 1993 and 1996 that show the presence of persistent unemployment crisis in Sudan amongst total population men and women since 1979, and rising trends of unemployment rates according to age, gender, location, regions, educational level, skill level, regions and employment status. As for the incidence of unemployment according to age groups in 1996, one should realize that for all population the highest rate of unemployment is reported amongst the youth population (15-24) it was estimated at $28.4 \%$ and for youth 15 years and over, it was estimated at $15.1 \%$, it followed by age group (25-54) estimated at $12.1 \%$, followed by age group above 64 estimated at $11.4 \%$, followed by age group (55-64) estimated at $10.3 \%$. For men the highest rate of unemployment is reported amongst the youth population (15-24) it was estimated at 22\%, followed by age group (55-64), it was estimated at $12.3 \%$, followed by age group above 64 , estimated at $11.9 \%$, followed by age group (25-54) estimated at $7.5 \%$, followed by 15 years and over estimated at $0.2 \%$. For women the highest rate of unemployment is reported amongst the youth population (15-24) it was

\footnotetext{
${ }^{29}$ See for example Arab labor organization and International Labor Organization (2007) recent statistics for 2006.
} 
estimated at $37.6 \%$ and for youth 15 years and over, it was estimated at $23.4 \%$, it followed by age group (25-54) estimated at $16.9 \%$, followed by age group (55-64) estimated at $11.2 \%$, followed by age group above 64 estimated at 6.7\%. Therefore, data for 1996 implies that except for the age group (55-64) for all other age groups, open unemployment amongst women exceeded men, the data also indicates that the incidence of open unemployment according to age and gender was higher among youth population, notably, youth women were likely to be more unemployed compared to youth men. Youth unemployment was high in 1997/1998; it increased from 29.0 in 1997 to 30.8 in 1998. The distribution of unemployment according to education level indicates that for total population, unemployment is high for primary education (33.8\%), followed by illiterate (29.9\%), illiterate/basic (21.6\%), secondary (11.2\%) and above secondary (3.5\%). The distribution of unemployment according to education level indicates that for men unemployment is high for primary education (33.6\%), followed by illiterate/basic (26.3\%), illiterate (24.1\%), secondary (11.4\%) and above secondary (4.4\%). The distribution of unemployment according to education level indicates that for women unemployment is high for primary education (33.9\%), followed by illiterate (33\%), illiterate/basic (17.3\%), secondary (10.9\%) and above secondary (2.8\%). The unemployment rate according to education level indicates that for all youth total unemployment (28.3\%) is high for above secondary (48.7\%), followed by secondary (35.6\%), primary (34.6\%), illiterate/basic (25.59\%) and illiterate (23.4\%). The unemployment rate according to education level indicates that for men unemployment (33.2\%) is high for above secondary (43.2\%), followed by secondary (24.4\%), primary (22.1\%), illiterate/basic (21.4\%) and illiterate (20.6\%). The unemployment rate according to education level indicates that for women unemployment (37.6\%) is high for primary (67.2\%) followed by above secondary (59.5\%), secondary (43.6\%), illiterate/basic (36.3\%) and illiterate (25.5\%). Data for 1996 on unemployment indicate that according to all educational level the structural distribution of unemployment for women is slightly different from men that coincided with the total population; in general women were likely to be more unemployed than men. Our findings based on the Sudan central bureau of statistics (2010) population census data for 2008 implies that the structure and distribution of the total population and labour force defined by age, gender, mode of living, main geographic areas and education attainment have several important implications in the employment rates and unemployment rates. Notably; we find that the total labour force, employment rates and unemployment rates for men are higher than women, for rural are higher than urban and for the north are higher than the south. Moreover, we find that the distribution of unemployment by age groups indicates that the highest unemployment is for the age group (15-24) 32.80\%, it followed by the age group age group (25-39) 32.44\%, age group (10-14) (13.80\%), age group (40-59) (14.57\%); and finally age group 60 and over (4.37\%).

\footnotetext{
${ }^{30}$ In this paper the terms Ministry of Labor, Ministry of Labor and Public Service, Ministry of Labor and Administrative Reform are used interchangeably to refer to Ministry of Labor, because the ministry of labour is named differently in different regimes.
} 
These findings are consistent with the findings from the 1993 population census and 1996 migration and labour force survey. These findings are also consistent with the structure and distribution of population in Sudan in 2008 defined by gender, mode of living and main geographical areas as we explained above. These findings are also consistent with the structure and distribution of population in Sudan in 2008 defined by gender, mode of living and main geographical areas as we explained above. Moreover, we find that for the economically active population both employment and (actual) unemployment rates are higher for primary education, followed by secondary and post secondary education respectively. Furthermore, we find that for the economically inactive population the expectations of no hope to find a job (or the potential unemployment) are higher for primary education, followed by secondary and post secondary education respectively- See Table 16 below. These findings together imply the importance of education in reducing the incidence of unemployment.

Table 16- Total population, labour force, economically active population, economically inactive population, employment and unemployment for population 10 years and above defined by age, gender, mode of living, main geographical areas and educational attainment in Sudan (2008).

\begin{tabular}{|c|c|c|c|c|c|c|c|c|c|}
\hline & $\begin{array}{l}\text { Total } \\
\text { Population }\end{array}$ & $\begin{array}{l}\text { Total labour } \\
\text { force }\end{array}$ & $\begin{array}{l}\text { Total Economically } \\
\text { Active }\end{array}$ & $\begin{array}{l}\text { Total } \\
\text { Employed }\end{array}$ & $\begin{array}{l}\text { Total } \\
\text { Unemployed }\end{array}$ & $\begin{array}{l}\text { Total } \\
\text { Unemployed }\end{array}$ & Total & \multicolumn{2}{|c|}{ REASON_REC } \\
\hline & & & & & & & $\begin{array}{l}\text { Total } \\
\text { economically } \\
\text { inactive }\end{array}$ & $\begin{array}{l}\text { No hope } \\
\text { to find job }\end{array}$ & $\begin{array}{l}\text { Full } \\
\text { time } \\
\text { Student }\end{array}$ \\
\hline \multicolumn{10}{|l|}{ All Sudan } \\
\hline \multicolumn{10}{|c|}{ All Sudan: Age groups } \\
\hline All Sudan & $100.00 \%$ & $100.00 \%$ & $43.68 \%$ & $84.07 \%$ & $15.93 \%$ & $100 \%$ & $48.80 \%$ & $10.28 \%$ & $40.70 \%$ \\
\hline $10-14$ & $18.58 \%$ & $18.58 \%$ & $4.19 \%$ & $7.08 \%$ & $2.52 \%$ & $15.81 \%$ & $13.18 \%$ & $2.78 \%$ & $21.03 \%$ \\
\hline $15-24$ & $27.98 \%$ & $27.98 \%$ & $9.95 \%$ & $17.56 \%$ & $5.23 \%$ & $32.80 \%$ & $15.89 \%$ & $3.50 \%$ & $18.02 \%$ \\
\hline $25-39$ & $28.56 \%$ & $28.56 \%$ & $15.98 \%$ & $31.42 \%$ & $5.17 \%$ & $32.44 \%$ & $10.13 \%$ & $2.36 \%$ & $1.70 \%$ \\
\hline $40-59$ & $17.48 \%$ & $17.48 \%$ & $10.60 \%$ & $21.93 \%$ & $2.32 \%$ & $14.57 \%$ & $5.69 \%$ & $1.74 \%$ & $0.14 \%$ \\
\hline 60 and over & $7.40 \%$ & $7.40 \%$ & $2.96 \%$ & $6.07 \%$ & $0.70 \%$ & $4.37 \%$ & $3.92 \%$ & $0.33 \%$ & $0.01 \%$ \\
\hline \multicolumn{10}{|c|}{ All Sudan: Educational attainment } \\
\hline No Qualifications & $4.81 \%$ & & $6.08 \%$ & $6.13 \%$ & $5.18 \%$ & $5.18 \%$ & $1.99 \%$ & $0.52 \%$ & $0.77 \%$ \\
\hline Primary/Junior & $11.65 \%$ & & $10.89 \%$ & $10.99 \%$ & $9.08 \%$ & $9.08 \%$ & $6.39 \%$ & $0.57 \%$ & $7.20 \%$ \\
\hline Secondary & $7.61 \%$ & & $7.77 \%$ & $7.88 \%$ & $5.76 \%$ & $5.76 \%$ & $3.70 \%$ & $0.37 \%$ & $4.25 \%$ \\
\hline Post Secondary & $3.80 \%$ & & $5.32 \%$ & $5.39 \%$ & $4.10 \%$ & $4.10 \%$ & $0.96 \%$ & $0.18 \%$ & $0.91 \%$ \\
\hline Khalwa & $3.45 \%$ & & $4.36 \%$ & $4.32 \%$ & $5.09 \%$ & $5.09 \%$ & $1.34 \%$ & $0.41 \%$ & $0.64 \%$ \\
\hline Not stated & $73.48 \%$ & & $71.66 \%$ & $71.42 \%$ & $75.97 \%$ & $75.97 \%$ & $36.41 \%$ & $8.76 \%$ & $27.71 \%$ \\
\hline \multicolumn{10}{|l|}{ All Sudan } \\
\hline Total & $100.00 \%$ & $100.00 \%$ & $43.68 \%$ & $84.07 \%$ & $15.93 \%$ & $100 \%$ & $48.80 \%$ & $10.28 \%$ & $40.70 \%$ \\
\hline Male & $50.07 \%$ & $50.07 \%$ & $28.99 \%$ & $57.23 \%$ & $9.14 \%$ & $57.33 \%$ & $17.28 \%$ & $5.57 \%$ & $22.44 \%$ \\
\hline Female & $49.93 \%$ & $49.93 \%$ & $14.69 \%$ & $26.84 \%$ & $6.80 \%$ & $42.67 \%$ & $31.52 \%$ & $4.71 \%$ & $18.26 \%$ \\
\hline Urban & $31.49 \%$ & $31.49 \%$ & $11.83 \%$ & $23.74 \%$ & $3.33 \%$ & $20.93 \%$ & $16.72 \%$ & $2.18 \%$ & $17.69 \%$ \\
\hline Rural & $61.48 \%$ & $61.48 \%$ & $28.47 \%$ & $53.78 \%$ & $11.40 \%$ & $71.57 \%$ & $29.21 \%$ & $7.24 \%$ & $22.16 \%$ \\
\hline Nomad & $7.03 \%$ & $7.03 \%$ & $3.38 \%$ & $6.54 \%$ & $1.20 \%$ & $7.51 \%$ & $2.87 \%$ & $0.86 \%$ & $0.85 \%$ \\
\hline \multicolumn{10}{|l|}{ North } \\
\hline Total & $80.58 \%$ & $80.58 \%$ & $30.10 \%$ & $57.32 \%$ & $11.59 \%$ & $72.73 \%$ & $43.16 \%$ & $6.91 \%$ & $37.07 \%$ \\
\hline Male & $40.41 \%$ & $40.41 \%$ & $22.14 \%$ & $43.60 \%$ & $7.08 \%$ & $44.41 \%$ & $14.64 \%$ & $3.69 \%$ & $20.20 \%$ \\
\hline Female & $40.17 \%$ & $40.17 \%$ & $7.96 \%$ & $13.71 \%$ & $4.51 \%$ & $28.31 \%$ & $28.52 \%$ & $3.22 \%$ & $16.86 \%$ \\
\hline Urban & $28.02 \%$ & $28.02 \%$ & $9.71 \%$ & $19.54 \%$ & $2.68 \%$ & $16.83 \%$ & $15.48 \%$ & $1.58 \%$ & $16.56 \%$ \\
\hline Rural & $45.53 \%$ & $45.53 \%$ & $17.01 \%$ & $31.23 \%$ & $7.71 \%$ & $48.40 \%$ & $24.81 \%$ & $4.46 \%$ & $19.66 \%$ \\
\hline Nomad & $7.03 \%$ & $7.03 \%$ & $3.38 \%$ & $6.54 \%$ & $1.20 \%$ & $7.51 \%$ & $2.87 \%$ & $0.86 \%$ & $0.85 \%$ \\
\hline \multicolumn{10}{|l|}{ South } \\
\hline Total & $19.42 \%$ & $19.42 \%$ & $13.58 \%$ & $26.75 \%$ & $4.35 \%$ & $27.27 \%$ & $5.64 \%$ & $3.38 \%$ & $3.63 \%$ \\
\hline Male & $9.65 \%$ & $9.65 \%$ & $6.85 \%$ & $13.63 \%$ & $2.06 \%$ & $12.92 \%$ & $2.64 \%$ & $1.89 \%$ & $2.24 \%$ \\
\hline Female & $9.76 \%$ & $9.76 \%$ & $6.73 \%$ & $13.12 \%$ & $2.29 \%$ & $14.35 \%$ & $3.00 \%$ & $1.49 \%$ & $1.39 \%$ \\
\hline Urban & $3.47 \%$ & $3.47 \%$ & $2.12 \%$ & $4.21 \%$ & $0.65 \%$ & $4.10 \%$ & $1.24 \%$ & $0.60 \%$ & $1.13 \%$ \\
\hline Rural & $15.95 \%$ & $15.95 \%$ & $11.46 \%$ & $22.55 \%$ & $3.69 \%$ & $23.17 \%$ & $4.40 \%$ & $2.78 \%$ & $2.50 \%$ \\
\hline
\end{tabular}

The fourth stylized fact on the incidence on unemployment in Sudan is that the persistence unemployment rate (especially among youth) is not only high but also show a tendency to increase over time in Sudan which is most probably related to the big mismatch between educational qualifications -supply- and labour market requirements- demand which is perceived from the observed structural change in the demand or changing trends in the share of employment over the period 1988/1989 and 2008. In particular, on average demand or priority in 
employment was concentrated among high secondary schools graduates over the period 1988/1989- 1996, but the trend changes and on average priorities in employment was turned to be concentrated in applied science colleges followed by social science and art colleges and finally higher institute diploma over the period 2001-2008. This can be attributed to changing trends and priorities from hiring high secondary school graduates to hiring university graduates, especially applied science college graduates, due to changes in higher educational policies, in particular, the higher education revolution lead to expansion in higher educational institutions and increase in student enrollment and graduation during and after 1990s. This can be interpreted as structural change in the demand for youth labour in favor of university graduates due to structural change in higher educational policies. We observe that despite the changing trend and priorities in reducing employment for higher secondary school graduates to increasing employment for university graduates. However, the structural change in the demand for youth labour in favor of increasing employment for university graduates should not hide the fact that unemployment among university graduates is surprisingly high and continue to increase. Somewhat surprisingly unemployment crisis was persistent especially among all youth graduates women and men in different field of specializations, even among graduates of applied science colleges. The majority of employment was for graduates in applied science colleges, followed by graduates in social science and art colleges and finally the minority for graduates of higher institute diploma. In general, men were likely to be more employed than women and women were likely to be more unemployed than men.

This fourth stylized fact implies the big mismatch between educational qualifications supply- and labour market requirement- demand. An important endogenous cause of youth unemployment is the mismatch between educational (qualifications-output) and labour market requirements. Deficiency in educational policies and labour market policies and inadequate planning, assessments and monitoring of policies to create consistency between attained and required education lead to serious mismatch between educational attainment and labour market requirements. To elaborate the mismatch and unemployment amongst university graduates we utilize the figures on registration and employment obtained from the federal public service recruitment board and we use the figures on registration to refer to supply of university graduates labour and use the figures on employment to refer to demand for university graduates labour, we calculate the differences between registration and employment to refer to the differences between supply of and demand for university graduates and to define unemployment, then we divide the figures on unemployment by the figures on registration to calculate the unemployment rates for university graduates. ${ }^{31}$ We find that unemployment amongst university graduates in all subjects

\footnotetext{
${ }^{31}$ One limitation is that the use of figures on registration and employment to refer to supply of and demand for university graduates labor respectively may be somewhat inaccurate and underestimate the actual figures on supply of and demand for university graduates, because not all university graduates looking for jobs are registered for the federal public service recruitment board and also because figures on employment may include university graduates unregistered for the federal public service recruitment board.
} 
or fields of specializations is persistent and high for more than two decades over the period 1984/85 and 2008. In particular, persistent and high unemployment rates were mostly amongst theoretical, social science and art colleges graduates and technical education high institute (diploma) graduates. Majority of employed graduates were within applied science colleges graduates, but this should not hide the fact that unemployment among this category is surprisingly also very high. This implies mismatch between attained education (educational policies) and required education in labour market (labour market policies) - see Figures 14-15 and Tables 18-20 below.

Figures 14-15- Youth Unemployment Rates in Sudan (\%) defined by gender (1995-2008)

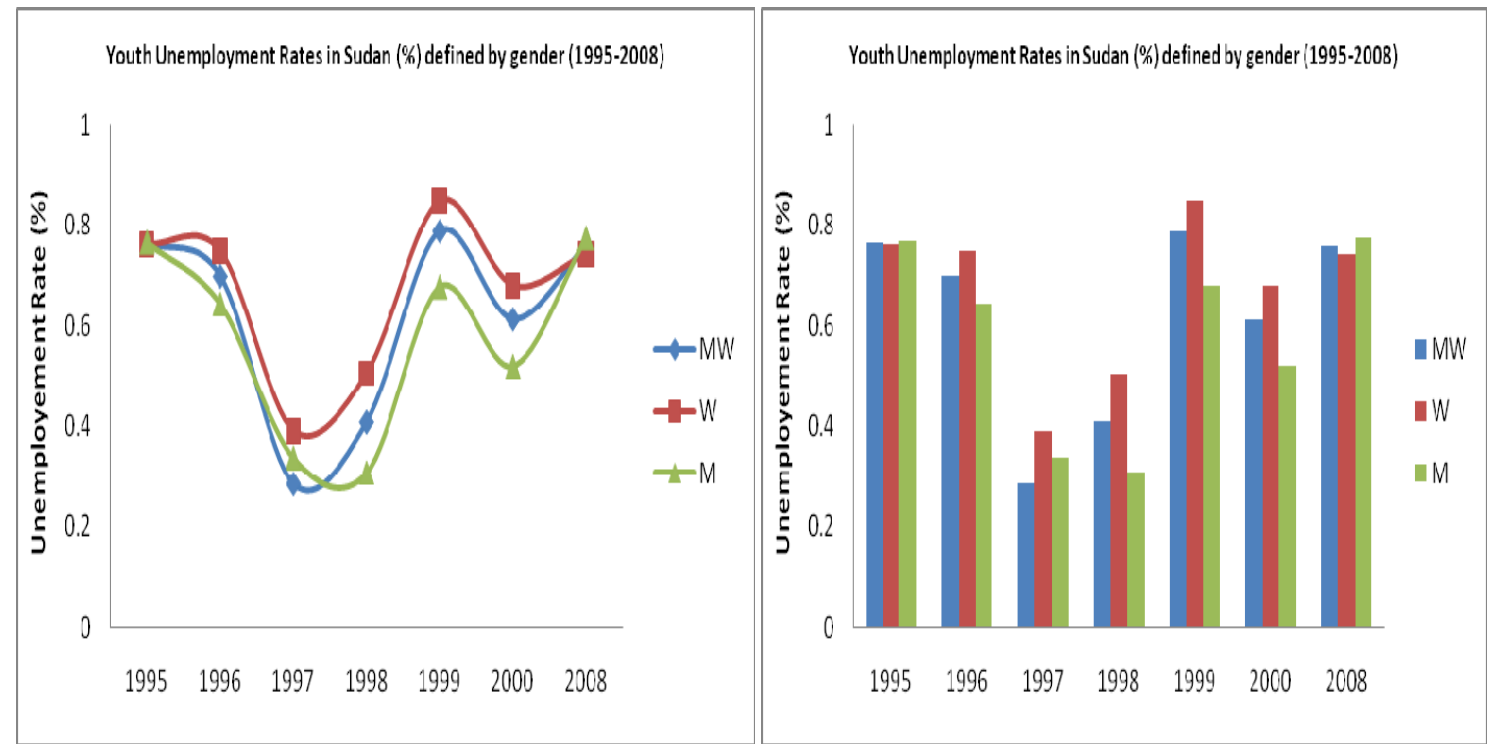

Source: Own calculations based on data from the federal public service recruitment board- Statistics and Research Administration

We find that the high unemployment is persistent amongst the university graduates with different fields of specializations over the period 1984/85-2008, for example, on average the rates of unemployment for all fields of specialization was estimated at 73\%, 82\%, 78\%, 81\%, 76\%, 69\%, 28\%, 41\%, 78\%, 61\% and 76\% in 1984/85, 1985/1986, 1986/87, 1987/88, 1995, 1996, 1997, 1998, 1999, 2000 and 2008 respectively - see Tables 18-19-20 below. In particular, for applied science colleges unemployment estimated at $64 \%, 85 \%, 75 \%, 48 \%, 40 \%, 75 \%$ in $1984 / 85$, 1985/1986, 1986/87, 1987/88, 2000 and 2008 respectively. As for social science and art colleges, unemployment estimated at 88\%, 66\%, 76\%, 90\%, 82\%, 93\% and 84\% in 1984/85, 1985/1986, 1986/87, 1987/88, 1990/91, 2000 and 2008 respectively. As for higher institute diploma, unemployment estimated at 74\%, 93\%, 84\%, 75\%, 49\% and 88\% in 1984/85, 1985/1986, 1986/87, 1987/88, 1990/91 and 2000 respectively- see Table 20 below.

Concerning the share of unemployment for university graduates for the period 1988/1989 - 2006, on average the share of employment for applied science colleges in total employment is changing and estimated at $37 \%, 63 \%, 41 \%, 19 \%, 12 \%, 19 \%, 18 \%, 18 \%, 2 \%$, 
$52 \%, 74 \%, 59 \%, 81 \%, 79 \%, 73 \%, 75 \%, 88 \%, 77 \%$, $90 \%$ and $81 \%$ for the years $1988 / 1989$, 1989/1990, 1991, 1992, 1993, 1994, 1995, 1996, 1997, 1998, 1999, 2000, 2001, 2003, 2004, 2005, 2006, 2007 and 2008 respectively. On average the share of employment for social science and art colleges in total employment is changing and estimated at 55\%, 22\%, 54\%, 31\%, 37\%, $17 \%, 75 \%, 9 \%, 1 \%, 13 \% 14 \%, 20 \%, 8 \%, 21 \%, 11 \%, 11 \%, 6 \%, 15 \%, 6 \%$ and $10 \%$ for the years 1988/1989, 1989/1990, 1991, 1992, 1993, 1994, 1995, 1996, 1997, 1998, 1999, 2000, 2001, 2003, 2004, 2005, 2006, 2007 and 2008 respectively. On average the share of employment for higher institute diploma in total employment is changing and estimated at $8 \%, 15 \%, 4 \%, 3 \%$, $2 \%, 5 \%, 1 \%, 0.1 \%, 9 \%, 2 \%, 4 \%, 2 \%, 0.4 \%, 0.35 \%, 0.3 \%$, and $2 \%$ for the years $1988 / 1989$, 1989/1990, 1991, 1992, 1993, 1994, 1995, 1996, 1997, 1998, 1999, 2000, 2001, 2003, 2004, and 2006 respectively. As for high secondary school, the average share of employment for high secondary school in total employment is changing and estimated at $46 \%, 48 \%, 62 \%, 1 \%, 72 \%$ $96 \%, 29 \%, 10 \%, 17 \%, 10 \%, 13 \%$, 3\%, and $5 \%$ for the years $1991,1992,1993,1994,1995$, 1996, 1997, 1998, 1999, 2000, 2003, 2007 and 2008 respectively. One should observe the changing trends in the share of employment over the period 1988/1989 and 2006. In particular, on average priorities in employment was concentrated among high secondary schools graduates over the period 1988/1989- 1996, but the trend changes and on average priorities in employment was turned to be concentrated in applied science colleges followed by social science and art colleges and finally higher institute diploma over the period 2001-2006- see Table 18 below. This can be attributed to changing trends and priorities from hiring high secondary school graduates to hiring university graduates, especially applied science college graduates, due to changes in higher educational policies, in particular, the higher education revolution lead to expansion in higher educational institutions and student enrollment during 1990s.

In 2000 unemployment was persistent among all graduates women and men in different fields of specializations. For all graduates all field of specialization only 35\% of graduates were employed and $65 \%$ were unemployed, in particular, only $29 \%$ of women were employed, but $71 \%$ of women were unemployed, only $42.5 \%$ of men were employed, but $57.5 \%$ of men were unemployed, women are likely to be more unemployed than men. For applied science colleges $56 \%$ of women were employed, but $44 \%$ of women were unemployed, $64.5 \%$ of men were employed, but $35.5 \%$ of men were unemployed, women are likely to be more unemployed than men. For social science and art colleges, only $6 \%$ of women were employed, but $94 \%$ of women were unemployed, only $8 \%$ of men were employed, but $92 \%$ of men were unemployed, women are likely to be more unemployed than men. For higher institutes (diploma) only 7\% of women were employed, but $93 \%$ of women were unemployed, only $18 \%$ of men were employed, but $82 \%$ of men were unemployed, women are likely to be more unemployed than men. Over the period 2000-2008, majority of employment was for graduates in applied science colleges (81\%, $75 \%, 77 \%, 73 \%, 78 \%, 88 \%, 76 \%, 90 \%$ and $81 \%$ ), followed by graduates in social science and 
art colleges (8\%, 20\%, 9\%, 11\%,11.4\%, 6.4\%, $14.7 \%, 6 \%$ and $10 \%)$, followed by expertise ( $0 \%, 0 \%, 0 \%, 0 \%, 6.1 \%, 1.1 \%, 1.1 \%, 1.2 \%$ and $4.7 \%)$, followed by the secondary school graduates $(10 \%, 5 \%, 13.4 \%, 13.3 \%, 4.1 \%, 4.3 \%, 5.3 \%, 2.9 \%$ and $4.8 \%)$ and finally minority for graduates of higher institutes (diploma) $(1.4 \%, 0.4 \%, 0.5 \%, 0.3 \%, 0.3 \%, 0 \%, 2.3 \%, 0 \%$ and 0\%) in 2000, 2001, 2002, 2003, 2004, 2005, 2006, 2007 and 2008 respectively. In 2000, for applied science colleges $60.4 \%$ of graduates were employed but $40 \%$ of graduates were unemployed, for social science and art colleges only $7 \%$ of graduates were employed, but $93 \%$ of graduates were unemployed and for higher institutes (diploma) only $12 \%$ of graduates were employed but $88 \%$ of graduates were unemployed. This implies that unemployment-namely for women-is high among the graduates of social science and art colleges and higher institutes (diploma). ${ }^{32}$ In 2001, majority of employment was for graduates in applied science colleges (75\%), followed by graduates in social science and art colleges (20\%), and finally minority for graduates of higher institute diploma (5\%). In 2004, majority of employment was for graduates in applied science colleges (78\%), followed by graduates in social science and art colleges (11.3\%), followed by expertise (6.1\%), followed by the secondary graduates (4.1\%) and finally followed by minority for graduates of higher institutes diploma (0.3\%). In 2005, majority of employment was for graduates in applied science colleges (88\%), followed by graduates in social science and art colleges (6.4\%), followed by the secondary graduates (4.3\%) and finally followed by minority of expertise (1.1\%). In 2006, majority of employment was for graduates in applied science colleges (76\%), followed by graduates in social science and art colleges (14.7\%), followed by the secondary graduates (5.3\%), followed by graduates of higher institute diploma (2.3\%) and finally followed by minority of expertise (1.1\%). In 2007, majority of employment was for graduates in applied science colleges (90\%), followed by graduates in social science and art colleges (6.1\%), followed by the secondary graduates (2.9\%), followed by expertise (1\%) and finally without any employment for higher institute diploma graduates (0\%). In 2008, majority of employment was for graduates in applied science colleges (81\%), followed by graduates in social science and art colleges (10\%), followed by the secondary graduates (5\%), followed by expertise (5\%) and finally without any employment for higher institute diploma graduates ( $0 \%)$. see Table 19 below. Over the period 2000-2008, the distribution of employment for graduates of all fields of specializations by gender indicates that men are likely to be more employed than women over the period (2000-2004, 2006), whereas the opposite is true for the period (2005, 2007-2008). For instance, the distribution of employment for graduates of all fields of specializations for men (52\%, 52\%, 52\%, 52\%, 51\%, 42\%, 55\%, 38\% and 43\%) and for women (48\%, 48\%, 48\%, 48\%, 49\%, 58\%, 47\%, 49\%, 58\%, 45\%, 62\% and 57\%) in 2000, 2001, 2003, 2004, 2005, 2006, 2007 and 2008 respectively. Over the period 2000-2008, the distribution of employment for graduates of applied science colleges and fields of specializations by gender

\footnotetext{
${ }^{32}$ See Sudan Federal Public Service Recruitment Board- Statistics and Research Administration
} 
indicates that men are likely to be more employed than women over the period (2000-2004), whereas the opposite is true for the period (2005-2008). For instance, the distribution of employment for graduates of applied science colleges and fields of specializations for men (53\%, $55 \%, 54 \%, 51 \%, 48 \%, 41 \%, 48 \%, 36 \%$ and $41 \%)$ and for women $(47 \%, 45 \%, 46 \%, 49 \%, 52 \%$, 59\%, 52\%, 64\% and 59\%) in 2000, 2001, 2003, 2004, 2005, 2006, 2007 and 2008 respectively. Over the period 2000-2008, the distribution of employment for graduates of art and social sciences colleges and fields of specializations by gender indicates that men are likely to be more employed than women over the period (2004,2006- 2007), whereas the opposite is true for the period (2000-2003, 2005, 2008). For instance, the distribution of employment for graduates of art and social sciences colleges and fields of specializations for men (39\%, 46\%, 36\%, 49\%, $61 \%, 43 \%, 80 \%, 56 \%$ and $39 \%)$ and for women $(61 \%, 54 \%, 64 \%, 51 \%, 39 \%, 57 \%, 20 \%, 44 \%$ and 61\%) in 2000, 2001, 2003, 2004, 2005, 2006, 2007 and 2008 respectively. Over the period 2000-2006, the distribution of employment for graduates of high institutes (diploma) indicates that men are likely to be more employed than women, for instance, the distribution of employment for graduates of high institutes (diploma) for men (65\%, 58\%, 73\%, and 85\%) and for women (35\%, 42\%, 27\% and 15\%) in 2000, 2001, 2004 and 2006 respectively. Over the period 2004-2008, the distribution of employment for graduates of expertise indicates that men are likely to be more employed than women, for instance, the distribution of employment for graduates of expertise for men (67\%, 75\%, 81\%, 65\% and 75\%) and for women (33\%, 25\%, 19\%, 35\% and 25\%) in 2004, 2005 and 2006 respectively. Over the period 2000-2008, the distribution of employment for graduates of secondary school indicates that men are likely to be more employed than women, for instance, the distribution of employment for graduates of secondary school for men (59\%, 42\%, 48\%, 56\% 54\%, 52\%, 61\%, 54\% and 57\%) and for women $(41 \%, 58 \%, 52 \%, 44 \%, 46 \%, 48 \%, 39 \%, 46 \%$ and $43 \%)$ in 2000, 2001, 2003, 2004, 2005, 2006, 2007 and 2008 respectively. see Table 19 below. ${ }^{33}$

Over the period (2000-2008) unemployment increased from about (61.2\%, 68.1\%, $51.9 \%)$ in 2000 to about (75.7\%, 74.2\%, 77.5\%) in 2008 for total, women and men graduates of all fields of specialization respectively. Over the period (2000-2008) unemployment increased from about (39.6\%, 43.7\%, 35.3\%) in 2000 to about (74.6\%, 72.1\%, 77.4\%) in 2008 for total, women and men graduates of applied science colleges and fields of specializations respectively. Over the period (2000-2008) unemployment decreased from about (93.1\%, 93.6\%, 92.4\%) in 2000 to about (84\%, 81.7\%, 86.6\%) in 2008 for total, women and men graduates of art and social sciences colleges and fields of specializations respectively. Over the period (2000-2008) unemployment increased from about (88.4\%, 93\%, 82\%) in 2000 to about (100\%, 100\%, 100\%) in 2008 for total, women and men for graduates of high institutes (diploma) respectively. Over the period (1995-2000) the distribution of unemployment by gender implies that for all fields of

\footnotetext{
${ }^{33}$ See Sudan Federal Public Service Recruitment Board- Statistics and Research Administration.
} 
specializations, applied science colleges and social sciences colleges and fields of specializations women are likely to be more unemployed than men. Whereas somewhat surprisingly, the opposite is true in 2008 as the distribution of unemployment by gender implies that for all fields of specializations, applied science colleges and social sciences colleges and fields of specializations men are likely to be more unemployed than women- see Table 20 below. Therefore, these findings provide further evidences on the serious and increasing trend of youth unemployment, notably unemployment of university, college and higher institute diploma in Sudan over the period (2000-2008). This implies the urgent need for implementation of sound policies to address the unemployment problem and increase employment opportunities in Sudan.

\section{Conclusions}

This paper explains the the general political context, socioeconomic characteristics of Sudan, and strategic problems for development in the Sudan and discusses the strategic problems facing the labour market in the Sudan and highlights the need for skill upgrading and development.

We begin by explaining the general socio-economic characteristics of Sudan economy, We explain several stylized facts on the labour market, First we explain the relation between the structure of labour market and the demographic structure, participation rates and economic activities, second we show the relation between the structure of labour market and the low skill level and brain drain problems and finally we examine the relation between the structure of labour market and the unemployment and youth unemployment problem in Sudan. We show that the differences in the structure and distribution of the total population defined by age, gender, mode of living and main geographic areas have several important implications in the structure of labour market, notably; we find that the labour force, participation rates, economic activities, skill level, employment rates and unemployment rates for men are higher than women, for rural are higher than urban and for the north are higher than the south.

Different from the several studies in the Sudanese literature we examine in detailed four stylized facts on the unemployment problem in Sudan including the presence of several types of unemployment; the interpretation of unemployment crisis in Sudan from two different endogenous and exogenous perspectives due to endogenous and exogenous causes; the high incidence of unemployment among youth population and the big mismatch between educational qualifications -supply- and labour market requirement- demand. Moreover, one advantage of our analysis is that we explain these stylized facts using a new data on population, employment and unemployment based on Sudan central bureau of statistic (2010) the Fifth Sudan Population and Housing Census (2008).

The major policy implication from our findings indicate that since the unemployment crisis is related or linked to the endogenous and exogenous causes explained above, therefore, reducing unemployment and enhancement of employment creation are most probably related or 
linked to several important factors and so policies intervention should deal with these endogenous and exogenous reasons or causes. The concerned parties in the solution of unemployment problem in the Sudan not only include the role of government and public sector, but also essential roles for the private sector and non-governmental organization as well as the civil society. This implies that one possible policies intervention for reducing unemployment and enhancement of employment creation are related or linked to increase employment and job opportunities in the public and government sector and increase employment and job opportunities in the private sector and improve of work conditions and employment policies and improve the roles and functions of the committee or board of recruitment. In addition to improvement of the quality of educational policies and improve the consistency (match) between educational qualifications (output) and labour market requirements. One major policy implication from our result implies that an increase in unemployment rates is positively and significantly correlated to an increase in inflation rates over the period (2000-2008), and so macroeconomic policies aimed at or targeting reducing inflation rates would also contribute to reduce unemployment rates. Therefore, macroeconomic policies should be used to reduce inflation in order to reduce unemployment in Sudan. Other policies include reducing the use of foreign workers and the influx of foreign refuges. Reduce the internal migration by avoiding civil war and conflict and solving of political problems and achieving political stabilization, ensure equity and fairness in the labour market. Attract foreign capital for the creation of new employment opportunities for domestic and local workers and upgrading skill levels. Create more job opportunities for poor by enhancing small and medium scale enterprises and provide unemployment insurance for poor. Enhance small and family projects. Implement balanced development strategies and improve of work conditions and availability of infrastructure and offer incentives to encourage work in the far states and finally, the use of oil revenues to create more and new employment opportunities for domestic workers in Sudan. It is important to realize that the unemployment crisis cannot be managed in a sustainable way through increased employment in an already inflated public sector and productive employment must be generated mostly in the private sector. Dealing with unemployment crisis and meeting the poverty alleviation challenge requires actions in wide-ranging areas of structural reforms to improve the business environment, encourage private sector investment, stimulate productivity growth, and enhance efficiency. Implementation of plans simultaneously targeting reducing unemployment and poverty, for instance, provision of more employment opportunities and poverty alleviation are related to improving infrastructures and facilities of value to the whole society, using labourintensive methods or schemes to generate employment for large numbers of poor people as well as mobilizing small, informal enterprises where many of the poorest workers are concentrated. These strategies expected to also lead to sustainable job creation and therefore poverty alleviation. 



\begin{tabular}{|c|c|c|c|c|c|c|c|c|c|c|c|c|c|c|c|c|c|c|c|c|c|c|}
\hline \multirow[t]{2}{*}{ Country } & \multicolumn{3}{|l|}{ Population ${ }^{c}$} & \multirow{2}{*}{$\begin{array}{l}\text { Labour } \\
\text { Force c } \\
\text { MF } 15 \\
\text { years and } \\
\text { over }(\%)\end{array}$} & \multicolumn{3}{|c|}{ Participation rate $(15-24)^{c}$} & \multicolumn{3}{|c|}{$\begin{array}{l}\text { \%Youth Unemployment in total } \\
\text { unemployment }(15-24 c)\end{array}$} & \multicolumn{3}{|c|}{$\begin{array}{l}\text { Youth Unemployment }(\% \\
)(15-24)^{c}\end{array}$} & \multicolumn{6}{|c|}{ Unemployment rate $(\%)$} & \multicolumn{3}{|c|}{ Labour productivity (US \$) c } \\
\hline & Total & $\begin{array}{l}\text { Growth } \\
\text { rate }(\%)\end{array}$ & $\begin{array}{l}\text { \% of } \\
\text { Youth } \\
(15-24)\end{array}$ & & $\begin{array}{l}\mathrm{M} \\
(\%)\end{array}$ & $\begin{array}{l}\mathrm{F} \\
(\%)\end{array}$ & $\begin{array}{l}\text { MF } \\
(\%)\end{array}$ & $\begin{array}{l}\mathrm{M} \\
(\%)\end{array}$ & $\begin{array}{l}\mathrm{F} \\
(\%)\end{array}$ & $\begin{array}{l}\text { MF } \\
(\%)\end{array}$ & $\begin{array}{l}\mathrm{M} \\
(\%)\end{array}$ & $\begin{array}{l}\mathrm{F} \\
(\%)\end{array}$ & $\begin{array}{l}\mathrm{MF} \\
(\%)\end{array}$ & $1990^{a}$ & $1995^{\mathrm{a}}$ & $2000^{a}$ & $2001^{\mathrm{a}}$ & $2002^{a}$ & $\begin{array}{l}2005- \\
2006^{c}\end{array}$ & 2002 & 2003 & 2004 \\
\hline Bahrain & 724,695 & 1.68 & 15 & 66.4 & 55.2 & 25.9 & 41.5 & 55.9 & 51.2 & 54 & 27.5 & 17.8 & 20.7 & na. & 10.0 & 12.0 & 12.0 & 20.5 & 3.40 & 35,493 & 39,814 & 47,787 \\
\hline Kuwait & $2,457,000$ & 1.32 & 19.6 & 76 & 38.3 & 30.22 & 34.6 & 54.32 & 38.3 & 46.32 & 13.3 & 24.4 & 23.3 & 0.5 & 1.5 & 2.1 & 2.3 & 7 & 1.67 & 94,462 & 118,659 & 152,926 \\
\hline Qatar & 789,392 & 1.6 & 21.1 & 78.84 & 28.3 & 7 & 17.5 & 54.7 & 36.3 & 45.2 & 11.6 & 50.9 & 17 & na. & na. & Na. & 2.7 & na & 2.00 & 370,006 & 435,417 & 512,413 \\
\hline UAE & $4,105,000$ & 1.72 & 16.2 & 80.76 & 53.1 & 20.4 & 38.5 & 45.8 & 53.6 & 47 & 6.4 & 5.7 & 6.3 & na. & na. & $\mathrm{Na}$. & 2.3 & na & 2.30 & 125,921 & 150,911 & 186,310 \\
\hline $\begin{array}{l}\text { Average high } \\
\text { income }\end{array}$ & $2,019,022$ & 2 & 18 & 76 & 44 & 20.9 & 33 & 52.7 & 44.9 & 48.1 & 14.7 & 24.7 & 17 & 0.5 & 1.5 & 2.1 & 2.43 & 7 & 1.99 & 196796.3 & 234995.7 & 283883 \\
\hline Oman & $2,416,000$ & 1.5 & 19.5 & 38.6 & 48 & 23.3 & 36 & na & na & $\mathrm{Na}$ & 17.7 & 22.3 & 19.7 & na & na & $\mathrm{Na}$ & 5 & na & 7.50 & 120,441 & 125,215 & \begin{tabular}{|l|}
144,289 \\
\end{tabular} \\
\hline KSA & $23,118,994$ & 2.4 & 18.2 & 50.7 & 28.3 & 7 & 17.5 & 62.9 & 54.1 & 60.4 & 24.4 & 31.6 & 25.9 & Na. & $\mathrm{Na}$. & 5.9 & Na. & 25 & 6.05 & 122,429 & 151,255 & 187,827 \\
\hline Algeria & $32,786,000$ & 1.6 & 22.6 & 41 & 20.3 & 16.15 & 21.5 & 79.6 & 20.4 & 70.1 & 47.2 & 56.4 & 45.6 & 19.8 & 28.0 & 27.3 & 28.5 & 31 & 15.30 & 10,180 & 12,727 & 16,400 \\
\hline Egypt & $69,997,000$ & 1.94 & 21.1 & 49.7 & 38.3 & 16.4 & 28.2 & 63.9 & 57 & 60.3 & 18.4 & 37.2 & 25.8 & 8.6 & 9.6 & 7.9 & 7.6 & 12 & 10.70 & 3,836 & 3,624 & 3,603 \\
\hline Lebanon & $\begin{array}{l}3,794,000 \\
\end{array}$ & 1.07 & 20.9 & 45.1 & 65 & 35.2 & 48.3 & 57.44 & 39.2 & 55.4 & 22.8 & 17.4 & 21.3 & na & na & $\mathrm{Na}$ & $\mathrm{Na}$ & 8.5 & 8.20 & 3,841 & 3,949 & 4,243 \\
\hline Morocco & $30,991,000$ & 1.5 & 20.2 & 52.6 & 63.8 & 24.5 & 44.9 & 37.59 & 31.7 & 35.87 & 16.2 & 14.4 & 15.7 & 15.4 & 16.0 & 13.7 & 12.8 & 19 & 15.70 & 3,106 & 3,476 & 3,901 \\
\hline Syria & $18,269,000$ & 2.6 & 20.2 & 44.9 & 63 & 19.85 & 42.5 & 58.92 & 54.5 & 57.19 & 16 & 33.7 & 19.9 & na & na & $\mathrm{Na}$ & $\mathrm{Na}$ & 20 & 8.08 & 3,689 & 3,468 & 3,852 \\
\hline Tunisia & $\begin{array}{l}10,130,000 \\
\end{array}$ & 1.08 & 20.8 & 46.3 & 18.1 & 25.94 & 20.2 & 64.25 & 67.3 & 65.21 & 28.9 & 20.2 & 26.5 & 16.2 & 16.2 & 15.5 & 15.0 & 15.4 & 14.20 & 4,694 & 5,064 & 5,389 \\
\hline $\begin{array}{l}\text { Libyan Arab } \\
\text { Jamahiriya }\end{array}$ & $6,097,000$ & 3.1 & 20.9 & 42.5 & 16 & 6.04 & 11.5 & 46.32 & 52.2 & 47.34 & 28.3 & 34.3 & 27.4 & na & na & $\mathrm{Na}$ & 30 & & 10.00 & 30,755 & 41,877 & 46,322 \\
\hline Djibouti & 600,000 & 3 & 20.2 & 64 & 48.7 & 24.3 & 37.5 & 35 & 46.2 & 62.2 & 30.5 & 41.5 & 37.8 & na. & na & 50 & na & 8.5 & 50.00 & 874 & 876 & 808 \\
\hline Jordan & $5,595,000$ & 2.3 & 21.6 & 37.8 & 46 & 10.05 & 28.9 & 64.07 & 69.2 & 66.01 & 35.5 & 55 & 38.9 & 16.8 & 14.7 & 14.7 & 14.7 & 16 & 13.00 & 11,522 & 11,814 & 13,327 \\
\hline Iraq & $27,954,000$ & 3 & 22.2 & 49 & 67.1 & 4.8 & 36 & 68.35 & 49.4 & 62.35 & 47.4 & 49.3 & 45.4 & na & na & $\mathrm{Na}$ & na & 19.8 & 29.50 & 16,179 & \begin{tabular}{|l|}
11,397 \\
\end{tabular} & 21,543 \\
\hline Palestine & $4,106,000$ & 3.4 & 21.2 & 6760 & 44.3 & 7.3 & 26.2 & $\begin{array}{ll}34.1 \\
\end{array}$ & 42.4 & 35 & 33.6 & $\begin{array}{ll}30.7 \\
\end{array}$ & 33.1 & $\mathrm{na}$ & na & $\mathrm{Na}$ & 25.5 & 50 & 23.50 & $\mathrm{na}$ & na & na \\
\hline $\begin{array}{l}\text { Average } \\
\text { medium } \\
\text { income }\end{array}$ & $18,142,615$ & 2 & 20.7 & 563 & 43.6 & 16.99 & 30.71 & 56.04 & 48.63 & 56.45 & 28.22 & 34.15 & 29.46 & 15.36 & 16.9 & $\begin{array}{l}19.29 \\
\end{array}$ & 17.39 & 20.47 & 16.29 & 27628.8 & 31228.5 & 37625.3 \\
\hline Somalia & $\begin{array}{l}10,082,000 \\
\end{array}$ & 1 & 20.2 & 72 & 47.6 & 29.4 & 42.2 & 37.8 & 44.3 & 61.5 & 31.3 & 47.4 & 43.5 & na. & na & na & na & 10 & 25.00 & 0 & 0 & 0 \\
\hline Yemen & $21,867,800$ & 3.5 & 21.4 & 46.3 & 51.5 & 19.9 & 36.1 & 57.35 & 55.8 & 57.58 & 20.5 & 13.5 & 18.7 & na. & 30 & 11.5 & na & & 16.30 & 6,470 & 7,489 & 8,743 \\
\hline $\begin{array}{l}\text { Mauritania } \\
\end{array}$ & $3,045,000$ & 2.4 & 21.4 & 47.1 & 35.3 & 22.45 & 31.3 & 58.31 & 59.1 & 60.25 & 48.7 & 41.3 & 44.3 & na. & 26.0 & 21 & na & 20.9 & 22.00 & 3,008 & 3,470 & 4,598 \\
\hline $\begin{array}{l}\text { Average low } \\
\text { income }\end{array}$ & $17,597,950$ & 2 & 21.5 & 54 & 37.4 & 19.5 & 30 & 55 & 55.4 & 59.7 & 34.3 & 36.4 & 37 & 16.6 & 23.53 & 14.83 & 11.6 & 16.53 & 20.45 & 2886.5 & 3324.3 & 4012 \\
\hline $\begin{array}{l}\text { Average } \\
\text { states }\end{array}$ & $14,967,709$ & 2 & 20.35 & 373 & 42.44 & 18.199 & 31.03 & 55.15 & 49.23 & 55.43 & 26.8 & 32.78 & 28.48 & 13.41 & 16.66 & 16.13 & 13.08 & 18.89 & 14.42 & 48448.7 & 56642 & 68349.4 \\
\hline Total Arab & $\begin{array}{l}314,321,881 \\
\end{array}$ & 2.4 & 20.7 & 53.3 & 42.4 & 18.2 & 31 & 50.59 & 48.6 & 51.62 & 26.4 & 30.8 & 30 & & & & & & & & & \\
\hline $\begin{array}{lr}\text { Middle } & \text { East } \\
\text { and } & \text { North } \\
\text { Africa } & \end{array}$ & & & & & & & & & & & & & 25.6 & 12.7 & 13.8 & 12.7 & 12.6 & na & na & na & na & na \\
\hline $\begin{array}{l}\text { Sub } \\
\text { Africa }\end{array}$ & & & & & & & & & & & & & 21.1 & & & & & & & & & \\
\hline $\begin{array}{ll}\text { South } & \text { East } \\
\text { Asia } & \end{array}$ & & & & & & & & & & & & & 16.4 & & & & & & & & & \\
\hline $\begin{array}{l}\text { Latin America } \\
\text { and Caribbean }\end{array}$ & & & & & & & & & & & & & 16 & & & & & & & & & \\
\hline World & & & & & & & & & & & & & 14.4 & & & & & & & & & \\
\hline
\end{tabular}

Sources: (a) World Economic Outlook (WEO). September 2002; The World Bank; staff estimates. I/ Simple Averages: nationals only for Bahrain. (b) Figures on inflation for 2005 are obtained from IMF (2005) International Economics, September, 2005 (c) Arab Labour Organization (2007) - Note figures for all countries refer to 2005, except for Jordan figure refers to 2006. 
Table (18) - Registration and employment of total university college and secondary school craduates for the years 1988/1989-2009) defined by specialization field

\begin{tabular}{|c|c|c|c|c|c|c|c|c|c|c|c|c|c|c|c|c|c|c|c|c|c|}
\hline & $1988 / 1989$ & $1989 / 1990$ & 1990 & 1991 & 1992 & 1993 & 1994 & T1995 & 1996 & 1997 & 1998 & 1999 & 2000 & 2001 & 2003 & 2004 & 2005 & 2006 & 2007 & 2008 & 2009 \\
\hline \multicolumn{22}{|l|}{ A) Applied Science Colleges } \\
\hline \begin{tabular}{|l} 
Employment \\
\end{tabular} & 502 & 389 & 655 & 750 & 534 & 782 & 1940 & 380 & 631 & 874 & 1370 & 677 & \begin{tabular}{|l|l|}
1541 \\
\end{tabular} & 2277 & 2269 & 2588 & 3775 & 2972 & 4776 & 2385 & \\
\hline$\%$ employed/total employed & $37.00 \%$ & $63.00 \%$ & $41.40 \%$ & $19.00 \%$ & $12 \%$ & $19.00 \%$ & $18.00 \%$ & $18.00 \%$ & $2.00 \%$ & $51.90 \%$ & $74.30 \%$ & $59.33 \%$ & $80.93 \%$ & $79.00 \%$ & $73.15 \%$ & $75 \%$ & $88.00 \%$ & $77 \%$ & $89.96 \%$ & $80.6 \%$ & \\
\hline \multicolumn{22}{|l|}{ (B) Social Science and Arts Colleges } \\
\hline Employment & 744 & 134 & 851 & 1229 & 1623 & 706 & 8063 & 193 & 413 & 227 & 259 & 228 & 147 & 598 & 331 & 376 & 273 & 571 & 326 & 293 & \\
\hline$\%$ employed/total employed & $55 \%$ & $22 \%$ & $53.79 \%$ & $31 \%$ & $37 \%$ & $17 \%$ & $75 \%$ & $9 \%$ & $1 \%$ & $13.48 \%$ & $14.05 \%$ & $19.98 \%$ & $7.72 \%$ & $21 \%$ & $10.67 \%$ & $11 \%$ & $6 \%$ & $15 \%$ & $6.14 \%$ & $9.90 \%$ & \\
\hline \multicolumn{22}{|l|}{$\begin{array}{l}\text { (C) Expertise } \\
\end{array}$} \\
\hline Employment & $0.00 \%$ & $0.00 \%$ & $0.00 \%$ & $0.00 \%$ & $0 \%$ & $0.00 \%$ & $0.00 \%$ & $0.00 \%$ & $0 \%$ & $0.00 \%$ & $0.00 \%$ & $0.00 \%$ & $0.00 \%$ & $0.00 \%$ & $0.00 \%$ & $0.00 \%$ & $0.00 \%$ & $0.00 \%$ & 54 & 140 & \\
\hline$\%$ employed/total employed & $0.00 \%$ & $0.00 \%$ & $0.00 \%$ & $0.00 \%$ & $0 \%$ & $0.00 \%$ & $0.00 \%$ & $0.00 \%$ & $0 \%$ & $0.00 \%$ & $0.00 \%$ & $0.00 \%$ & $0.00 \%$ & $0.00 \%$ & $0.00 \%$ & $0.00 \%$ & $0.00 \%$ & $0.00 \%$ & $1.02 \%$ & $4.73 \%$ & \\
\hline \multicolumn{22}{|l|}{ (D) Higher Institutes (Diploma) } \\
\hline Employment & 1102 & 93 & 76 & 194 & 111 & 90 & 554 & 33 & 44949 & 1144 & 34 & 44 & 26 & 112 & 11 & 11 & na & 91 & $0.00 \%$ & $0.00 \%$ & \\
\hline$\%$ employed/total employed & $77.60 \%$ & $15.00 \%$ & $4.80 \%$ & $4.00 \%$ & $3 \%$ & $2.00 \%$ & $5.00 \%$ & $1.00 \%$ & $0.10 \%$ & $8.55 \%$ & $1.84 \%$ & $3.86 \%$ & $1.37 \%$ & $0.40 \%$ & $0.35 \%$ & $0.32 \%$ & & $2.3 \%$ & $0.00 \%$ & $0.00 \%$ & \\
\hline \multicolumn{22}{|l|}{ (E) Secondary School } \\
\hline Employment & Ina & na & $0.00 \%$ & 1829 & 2069 & 2593 & 134 & 1543 & 29296 & 493 & 181 & 192 & 190 & na & 411 & na & $\mathrm{na}$ & na & 153 & 141 & \\
\hline$\%$ employed/total employed & $\ln$ & $\mathrm{na}$ & $0.00 \%$ & $46 \%$ & $48 \%$ & $62 \%$ & $1.3 \%$ & $72 \%$ & $96.5 \%$ & $29.28 \%$ & $9.82 \%$ & $16.83 \%$ & $9.98 \%$ & $\operatorname{lna}$ & $13.25 \%$ & na & $\mathrm{na}$ & na & $2.88 \%$ & $4.77 \%$ & \\
\hline Total & & & 1582 & & & & & & & 1684 & 1844 & 1141 & 1904 & & 3102 & & & & 5309 & 2959 & 8143 \\
\hline \begin{tabular}{|l|} 
Registration \\
\end{tabular} & na & na & & na & na & na & na & na & na & & & & & 7661 & 13390 & 15019 & 14155 & 17141 & & & \\
\hline Employment & 1348 & 616 & & 4002 & 4337 & 4171 & 10691 & 2149 & 30373 & & & & & 2888 & 3201 & 3463 & 4280 & 3882 & & & \\
\hline$\%$ employ/registered & $\mathrm{na}$ & $\mathrm{Na}$ & & na & na & $\operatorname{lna}$ & na & $\ln$ & $\ln a$ & & & & & 0.38 & 0.24 & 0.23 & 0.30 & 0.23 & & & \\
\hline \% unemployed & na & $\mathrm{Na}$ & & na & Ina & Ina & Ina & Ina & Ina & & & & & 0.62 & 0.76 & 0.77 & - & 0.77 & & & \\
\hline
\end{tabular}

Source: Adapted from the federal public service recruitment board- Statistics and Research Administration. 
Table (19) - Distribution of employment of university, college, higher institute, experts and secondary school graduates for the years (1995 - 2008) defined by gender and specialization field

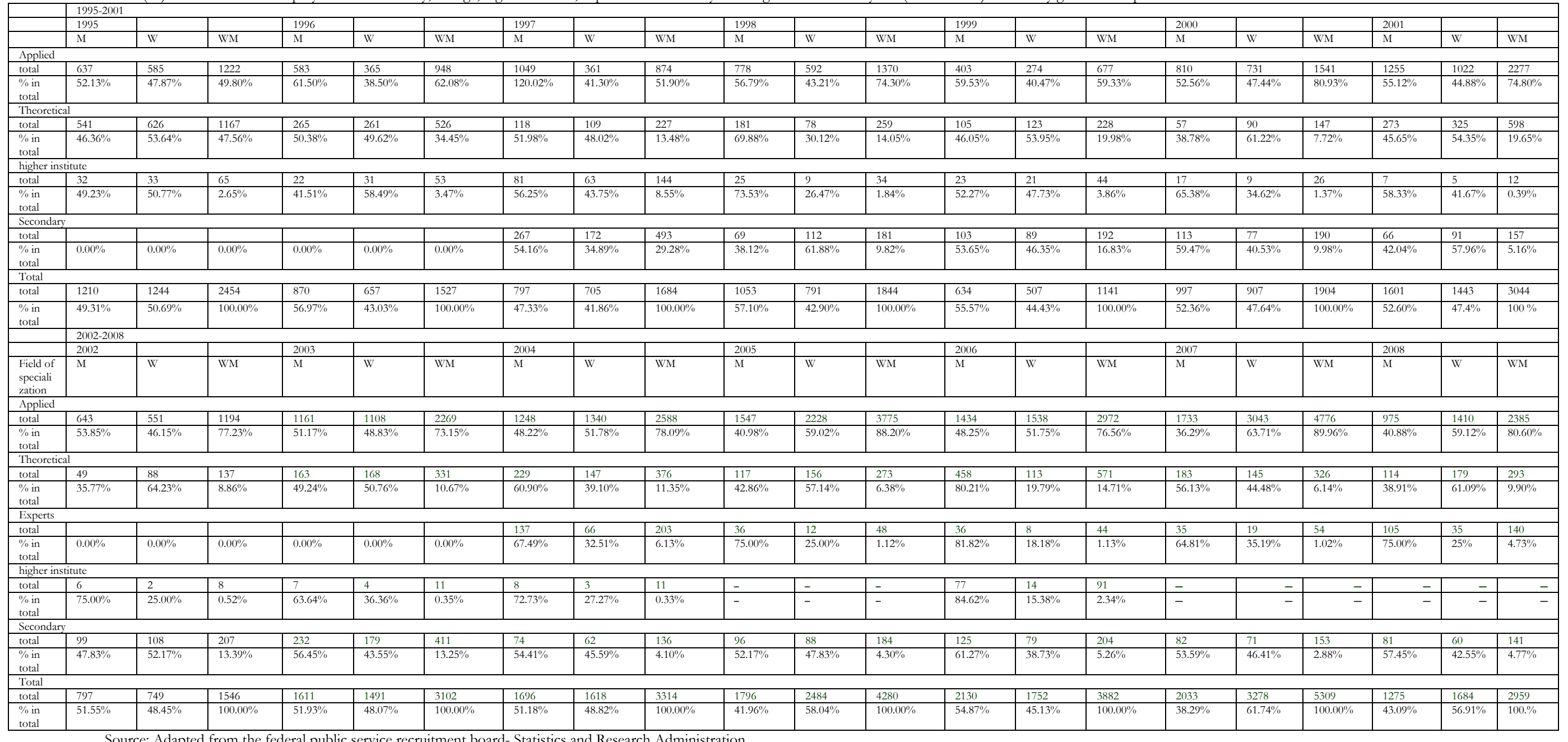

Source: Adapted from the federal public service recruitment board- Statistics and Research Administration. 
Table (20) - Registration, employment and unemployment of university, college, higher institutes, experts and secondary school graduates for the years $(1984 / 1985-2008)$ defined by gender and specialization field

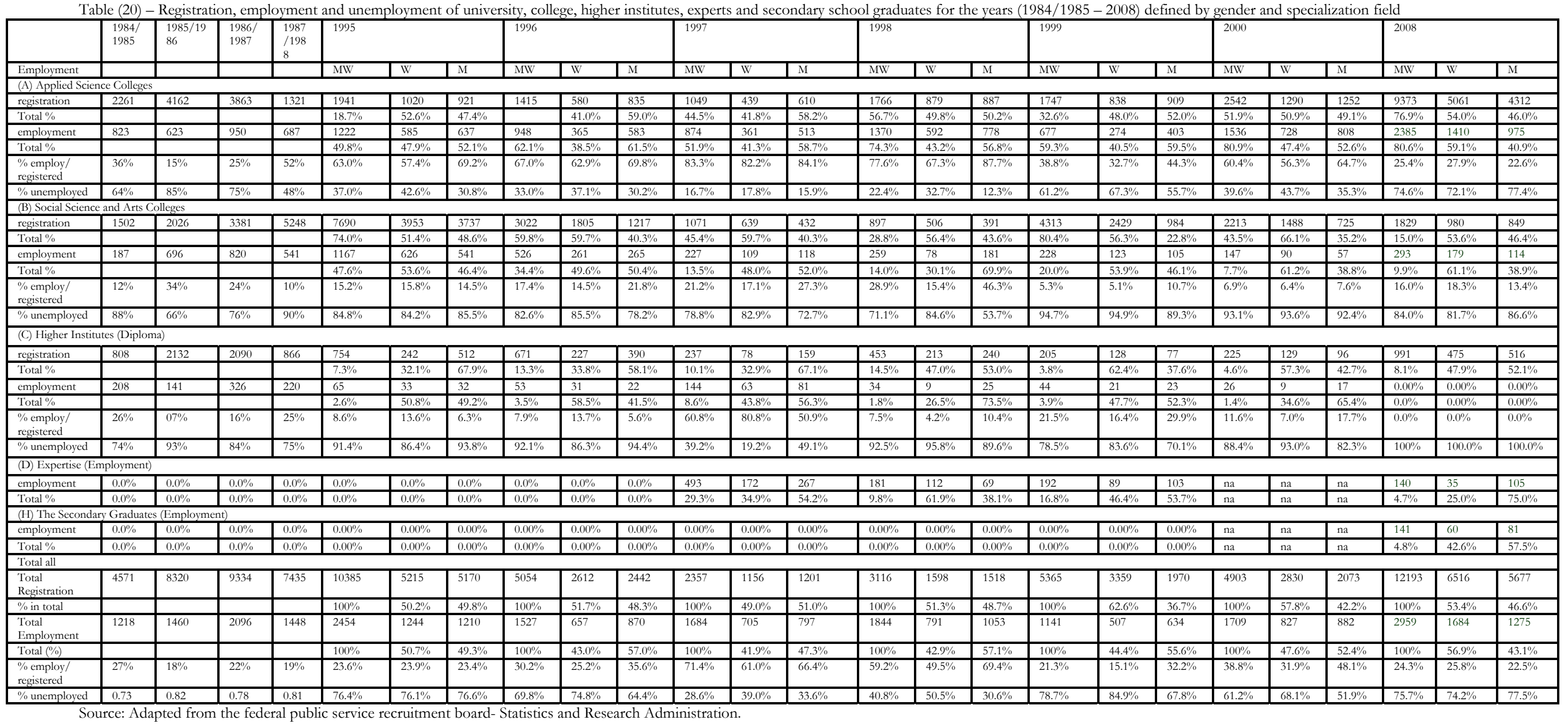




\section{References}

Corden, W.M. (1984) “Booming Sector and Dutch Disease Economics: Survey and Consolidation,” Oxford Economic Papers 36 (November 1984): 360-62.

Elbadawi, I. A. and Kaltani L. (2007) “The Macroeconomics of Oil Booms: Lessons for SSA,” Development Economics Research Group, Economists' Forum, April 19, 2007. Paper presented at the Ministry of Finance and National Economy and the World Bank "Macroeconomic and Fiscal Federalism Workshop" 14 - 31 July, 2007, Khartoum, Sudan.

IMF International Monetary Fund, World Economic Outlook Database, April 2009, www.imf.org

IMF Report on the implications of the Global Financial Crisis for Low-Income Countries, March 2009, p.48: http://www.imf.org/external/pubs/ft/books/2009/globalfin/globalfin.pdf

IMF projection for 2008

IMF First Review of Performance Under the 2007-08 Staff-Monitored Program, June 2008, p.2

IMF Report on the implications of the Global Financial Crisis for Low-Income Countries, March 2009, p.50

International Energy Agency Estimates; International Energy Annual, IPM www.eia.doe.gov/cabs/Sudan/Oil.html International Labour Organization (2007)

Palma, G. (2003) “Four Sources of de-industrialisation and a new concept of the Dutch Disease,” Unpublished paper presented at UNU-INTECH Research Seminar Series 2004-2, 19 May 2004: p. 21

Shaban, R. A., Assaad, R. and Al-Qudsi, S. S. (1995) "The Challenge of Unemployment in the Arab Region;” International Labour Review, Vol. 134, 1995, at www.questia.com/PM.qst?a=o\&se=gglsc\&d=5000320794 accessed in November 20, 2007.

Sudan Central Bureau of Statistics- Department of Internal Commerce and Pricing.

Sudan Central Bureau of Statistics Population Census Data (2010): The Fifth Sudan Population and Housing Census (2008)

Sudan Central Bureau of Statistics (2008) “Sudan statistical year book: Sudan statistics 2008,” Sudan Central Bureau of Statistics, Sudan Ministry of the Cabinet..

Sudan Central Bureau of Statistics (2008) “Sudan statistical year book: Sudan statistics 1990- 2008," Sudan Central Bureau of Statistics, Sudan Ministry of the Cabinet: pp. 3, 39-43.

Sudan Central Bureau of Statistics Statistical Year Book (2008), "Sudan Economy in Figures: General Information” pp. XI-XII.

Sudan Central Bureau of Statistics (2007) “Sudan statistical year book: Sudan statistics 2007,” Sudan Central Bureau of Statistics, Sudan Ministry of the Cabinet.

Sudan Central Bureau of Statistics: Volume 2, Economic and Social Characteristics.

Sudan Factsheet Human Rights \& Oil workshop - January 31, 2003, pp 1-2.

Sudan Health and Household Survey 2006

Sudan Oil fact sheet on Sudan, September 2006, produced by C. Pinaud for UnderstandingSudan.org, 2006, pp.1-2

Sudan Ministry of Finance and National Economy- Annual Economic Survey Report (Various Issues: 1997-2007)

Sudan Ministry of Finance and National Economy (2008) Unpublished Report (2008),

Sudan Ministry of Finance and National Economy (2006) “The Performance of Sudan Economy 2000-2005”

April, 2006, pp: 16-18

Sudan Ministry of Finance and National Economy (2005) "the Sudan Economy in Figure: 2000-2005" (Second edition), Ministry of Finance and National Economy, Macroeconomic Policies and Programme Directorate MEPPD, Khartoum, Sudan, (2005).

Sudan Ministry of Finance and National Economy (2002) "the Sudan Economy in Figure: 1990-2002" (First edition), Ministry of Finance and National Economy, Macroeconomic Policies and Programme Directorate MEPPD, Khartoum, Sudan, (2002), p 27.

Sudan Ministry of Finance and National Economy- Annual Economic Survey 2000, Table 7-2, p. 10.

Sudan Ministry of Energy and Mining (2008) “Unpublished Report” (2008), Khartoum, Sudan.

Sudan Ministry of Foreign Trade and Central Bank of Sudan Annual Foreign Trade Statistical Digest various issues (1997-2010): 2006: p. 20, p. 38. 2005: p. 38, p.20. 2004: p. 20, p. 39. 2002: p. 9, p. 24. 2000: p. 9, p. 24. 1998: pp. 12-13, pp. 33-34. 1997: pp. 12-13, pp. 33-34, 2010.

Sudan Ministry of Industry (2005) “The Comprehensive Industrial Survey (2005)”, Khartoum, Sudan, July, 2005: The executive summary of the comprehensive industrial survey, (2005), p. 29.

Sudan Ministry of International Cooperation.

Sudan Ministry of Investment unpublished statistics and data from the feasibility studies (2009)

Sudan Ministry of Labour and public service Annual Economic Reports (various issues)

Sudan Ministry of Labour and public service, Central Bureau of Statistics- Migration and Labour Force Survey 1996.

Sudan Ministry of Labour Report 2004-2005 “Labour Market and Unemployment in Sudan”.

Sudan Ministry of Labour and public service Migration and Labour Force Surveys 1990

Sudan Ministry of Labour and Administration Reform- Department of Planning and Monitoring and Follow-up

Sudan Ministry of Labour and Public Service - Official estimates- Annual Reports

The United Nations Development Programme UNDP- The Arab Human Development Report (2003): Arab human development report 2003: Building a knowledge society. Amman, Jordan: UNDP-RBAS; New York, NY: National Press. Table 5.1 p.102.

The Central Bank of Sudan Annual Report (Various Issues: 1999-2009)

The Central Bank of Sudan Annual Report (2009), p. 84. 
The Central Bank of Sudan Annual Report (2004), p. 36.

The Central Bank of Sudan $44^{\text {th }}$ Annual Report (2004): Appendix No. XVI, pp. 188-189; and $48^{\text {th }}$ Annual Report (2008): Appendix No XVI-B-XVII-B, pp.158-164).

The Central Bank of Sudan (2004) "The impacts of technologies on the banking sector in Sudan during the period 1999-2003” Report of the Central Bank of Sudan, Statistical and Research Department Series, Issue No. 6- pp. 13, 36.

The Federal Public Service Recruitment Board- Statistics and Research Administration

The United Nations Development Programme UNDP (2010) UNDP Sudan Country profile of Human Development Indicators (2010): http://hdrstats.undp.org/en/countries/profiles/SDN.html, accessed on December 22, 2010.

The United Nations Development Programme UNDP (2010) “Human Development Report 2010: The Real Wealth of Nations: Pathways to Human Development," Human Development Report 2010 -20th Anniversary Edition New York, NY: UNDP, Palgrave Macmillan, Statistical Tables, Statistical Annex, Table 12: Decent Work, p.191.

The United Nations Development Programme UNDP (2009) “Human development report 2009: Overcoming barriers: Human mobility and development. New York, NY: UNDP."

The United Nations Development Programme UNDP- HDR (2007/2008) “Human development report 2007/2008: Fighting climate change: Human solidarity in a divided world”. New York, NY: UNDP pp. 231-232, 392-293.

The United Nations Millennium Development Goals in Sudan "Sudan Millennium Development Goals Interim Unified Report, 2004”: http://www.sd.undp.org/mdg sudan.htm, accessed on June 01

The United Nations Development Programme UNDP in Sudan (2006) "Macroeconomic Policies for Poverty Poverty Reduction: The Case of Sudan," Khartoum, Sudan, 2006.

The United Nations Development Programme UNDP (2006): “employment generation and poverty reduction," Chapter Nine in the 2006 UNDP report on "Macroeconomic Policies for Poverty Reduction: the case of Sudan” published for the UNDP in Sudan, Khartoum, Sudan, June 1006 pp. 92-94.

The UN Resident Coordinator's Support Office, Khartoum, Sudan: http://www.sd.undp.org/mdg_fact.htm, accessed in June 01, 2010.

The World Bank (WB-DTS) (2008) "Revitalizing Sudan’s Non-Oil Exports: A Diagnostic Trade Integration Study (DTIS) Prepared for the Integrated Framework Program (December 2008)" A Revised version of "Sudan Diagnostic Trade Integration Study (DTS), Poverty Reduction and Economic Management 2- Africa region,, Draft: may 2, 2008, Decision Meeting: May 13, 2008”: pp. viii-ix; 1-7: http://www.integratedframework.org/files/english/Sudan\%20DTIS\%20final.pdf

The World Bank, (2003), Vol. 1: 44.

The World Bank Sudan Economic Brief April 2009.

The World Development Indicators (WDI)/ IMF/World Bank Staff Estimate (2008)

The World Development Indicator database: WDI (2005).

The World Investment Report (2002) UNCTAD.

Wikipedia: http://en.wikipedia.org/wiki/Brain_drain, accessed November 14, 2010.

Wikipedia: http://en.wikipedia.org/wiki/Second_Sudanese_Civil_War: Accessed in November 10, 2010.

Wikipedia: http://en.wikipedia.org/wiki/Sudan Accessed June 01 ${ }^{\text {st }}, 2010$ 


\section{The UNU-MERIT WORKING Paper Series}

2011-01 Mitigating 'anticommons' harms to research in science and technology by Paul A. David

2011-02 Telemedicine and primary health: the virtual doctor project Zambia by Evans Mupela, Paul Mustard and Huw Jones

2011-03 Russia's emerging multinational companies amidst the global economic crisis by Sergey Filippov

2011-04 Assessment of Gender Gap in Sudan by Samia Satti Osman Mohamed Nour

2011-05Assessment of Effectiveness of China Aid in Financing Development in Sudan by Samia Satti Osman Mohamed Nour

2011-06 Assessment of the Impacts of Oil: Opportunities and Challenges for Economic Development in Sudan by Samia Satti Osman Mohamed Nour

2011-07 Labour Market and Unemployment in Sudan by Samia Satti Osman Mohamed Nour 